A SPRING FLORA FOR HIGH SCHOOLS COWLES AND COULTER

QK

47

C 732 



\section{므 \\ $\Longrightarrow \mathrm{m}$}

$\overline{\overline{\underline{\underline{ }}}} \square$

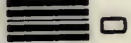

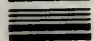

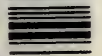





A SPRING FLORA

\title{
FOR HIGH SCHOOLS
}

\author{
BY \\ HENRY C. COWLES, PH.D. \\ ASSOCIATE PROFESSOR OF PLANT BCOLOGY \\ IN THE UNIVRRSITY OP CHICAGO \\ AND \\ JOHN G. COUlter, Рh.D. \\ CRITIC TEACHER OF BIOLOGY \\ UNIVERSITY HIGH SCHOOL, NORMAL, ILL. \\ AUTHOR OF "PLANT LIFE AND PLANT USES"
}

AMERICAN BOOK COMPANY 
COPYRIGHT, 1915, BY

AMERICAN BOOK COMPANY

A SPRING FLORA

E. P. 1.

9153 


\section{PREFACE}

The purpose of this Flora is to provide, especially for young people in high schools, a ready means for the identification of the more common and wide spread spring flowering plants.

Many species, locally abundant, are omitted. The aim has been to include those of chief ecological importance, and of not too great taxonomic difficulty, in the range as a whole; those which "every amateur botanist should know". Besides these, he should, of course, know those of local importance. The intentional omissions on account of taxonomic difficulties are of grasses, sedges, rushes, and of most willows and hawthorns.

High school teachers generally feel the need of making their pupils acquainted with as many of the frequent and important plants as opportunity permits. Field or laboratory studies with this end in view are conducted to better advantage in the spring, at the end of the course, than at its beginning, in fall or mid-year. It is believed that this book, with its one comprehensive key and its abundant illustrations, may help in the accomplishment of this end more directly than the complete manuals.

The key is almost strictly dichotomous throughout and deals only with such characteristics as are readily observable in spring. There are brief descriptions of 380 familiar plants which flower before July in the North Central and Eastern States.

Henry Chandler Cowles John Gaylord Coulter 


\section{TABLE OF CONTENTS}

PAGE

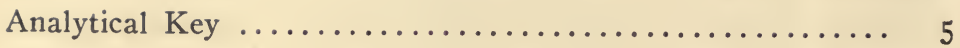

Descriptive Flora $\ldots \ldots \ldots \ldots \ldots \ldots \ldots \ldots \ldots \ldots . \ldots \ldots$

English and Metric Scale.................... I26

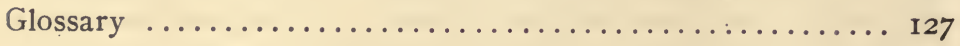

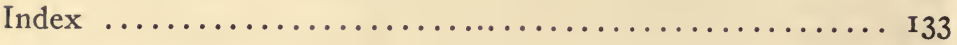




\section{ANALYTICAL KEY}

a. TREES. (For next related division go to page $9^{*}$.)

b. Leaves small or narrow, usually needle- or awl-shaped (Pine family).

c. Leaves always present, $i$. $e_{\text {e. }}$, tree evergreen.

d. Leaves in clusters of two or more on ordinary branches (Pine).

e. Leaves five in a cluster. White PINE, PINUS STROBUS (p. 30).

e. Leaves two or three in a cluster.

f. Cone scales without spines or prickles.

g. Leaves long, i. e., 9-16 cm. RED PINE, PINUS RESINOSA (p. 3i).

g. Leaves short, i. e., 2-4 cm. JACK Pine, PINUS BANKSIANA (p. 3 I).

f. Cone scales armed with a spine or prickle.

g. Leaves rigid.

h. Leaves two in a cluster. JACK PINE, PINUS BANKSIANA (p. 3 I).

h. Leaves three in a cluster. Pitch PINe, PINUS RIGIDA (p. 3 I).

g. Leaves flaccid.

h. Scale spine minute, i. e., I mm. or less in length.

Yellow Pine, PINUS EChinata (p. 31 ).

h. Scale spine 2-3 $\mathrm{mm}$. in length.

Jersey Pine, PinUs Virginiana (p. 3 I).

d. Leaves single.

e. Leaves not opposite, needle-snaped.

e. Leaves opposite.

HeMLock, TSUGA CANADENSIS (p. 3 I).

f. Fruit a cone of separate scales; leaves scale-shaped.

Arbor Vitae, THUJA OCCIDENTALIS (p. 32).

1. Fruit a berry; leaves needle- or scale-shaped:

RED CEDAR, JUNIPERUS VIRGINIANA (p. 32).

c. Leaves absent part of the year, $i_{0} e_{0}$, tree deciduous; leaves many in a cluster on a short branch.

TAMARACK, IARIX IARICINA (p. 3 I).

b. Leaves not needle- or awl-shaped; trees not evergreen.

c. Leaves and branches opposite (p. 6).

d. Inflorescence white.

e. Corollas greenish, surrounded by a showy white involucre.

Flowering Dogwood, CORNUS FLORIDA (p. 100).

๑. Corollas white; involucre wanting.

BLACK HAW, VIBURNUM IENTAGO (p. IIg).

d. Inflorescence not white.

e. Flowers appearing decidedly before the leaves (p. 6).

f. Bark whitish to grayish, smooth except on basal parts of large trees; leaves simple (Maple).

g. Petals none; fruit woolly; leaves deeply lobed.

Silver Maple, ACER SACCharinum (p. 91).

g. Petals present; fruit smooth; leaves somewhat lobed.

Red Maple, ACER RUBRUM (p. 9r).

f. Bark rough except on the smaller branches; twigs coarse; leaves compound $(A s h)$.

g. Old bark deeply furrowed; calyx present.

White Ash, FraXiNus AMERICANA (p. 106).

"The words "for next related division go to" are to be understood with similar references which follow. 
g. Old bark light, scaly; calyx wanting.

Black Ash, FRAXINUS NIGRA (p. ro6).

e. Flowers appearing with or after the leaves.

f. Leaves simple; bark gray; flowers polygamous.

1. Leaves compound.

Surar Maple, ACER SacCharum (p. 9r).

g. Leaves pinnate; flowers dioecious.

g. Leaves palmate; flowers irregular.

Box ElDER, ACER NEGUNDO (p. 92).

BUCKEYE, AESCULUS GLABRA (p. 92).

c. Leaves and branches not opposite.

d. Flowers monoecious or dioecious, one or both sorts in catkins (p. 8).

e. Flowers appearing decidedly before the leaves, both sorts in catkins.

f. Flowers monoecious (Alder).

g. Leaves doubly serrate, rounded at base, usually downy.

Hoary Alder, ALNUS INCANA (p. 49).

g. Leaves regularly serrate, acute at base, usually smooth.

SMоoti Alder, ALNUS RUGOSA (p. 49).

f. Flowers dioecious (Poplar).

g. Stigmas slender; catkin scales silky; stamens less than twenty.

h. Bud scales smooth, shiny, sharply pointed; catkin scales with deep and nearly equal linear divisions.

TrEMBLiNg AsPen, POPULUS TREMULOIDES (p. 44).

h. Bud scales downy, dull brown, rounded or abruptly pointed; catkin scales with unequal small divisions.

LARGe-Toothed Aspen, POPULUS GRANDIDENDATA (p. 44).

g. Stigmas stout and fleshy; catkin scales smooth or nearly so; stamens more than twenty.

h. Buds dark brown, very fragrant; stamens thirty or less; capsule two-valved. Balsam Poplar, POPUlUS Balsamifera (p. 44).

h. Buds light brown, very glutinous; stamens sixty or more; capsule 3-4 valved. Cortonwood, POPULUS DELTOIDES (p. 45).

๑. Flowers appearing with or after the leaves.

f. Both sorts of flowers conspicuously in catkins (p. 7).

g. Bark smooth, usually papery; lenticels horizontal, conspicuous; flowers monoecious (Birch).

h. Bark and twigs sweet and aromatic.

1. Bark dark brown, not detaching in filmy layers.

SWeet Birch, BETULA LENTA (p. 48 ).

i. Bark yellowish or grayish, detaching in filmy layers.

Yellow Birch, BETULA IUTEA (p. 48).

h. Bark and twigs not sweet and aromatic.

i. Bark brownish or reddish. RIVER BIRCH, BETULA NIGRA (p. 48).

1. Bark white.

j. Bark dull white, not readily exfoliating; leaves triangular, long taper-pointed. GRAY BIRCH, BETULA POPULIFOLIA (p. 49).

j. Bark creamy white, exfoliating readily; leaves not triangular nor taper-pointed.

Paper Birch, Betula ALBA PAPYRIferA (p. 49).

g. Bark roughish, not papery; lenticels not horizontal nor conspicuous.

h. Leaves heart-shaped; calyx present.

Red Mulberry, MORUS RUBRA (p. 53).

h. Leaves not heart-shaped; calyx wanting; flowers dioecious (Willow). 
i. Leaves linear to narrowly lanceolate, short petioled (less than $1 \mathrm{~cm}$.), green on both surfaces; branchlets detaching readily.

Black Willow, SALIX NIGRA (p. 42).

i. Leaves broadly lanceolate, glaucous beneath; petioles $I-3 \mathrm{~cm}$. long; branchlets not detaching readily.

Peach-leaved Willow, Salix amygdalotdes (p. 42).

f. Only the staminate flowers conspicuously in catkins.

g. Leaves simple.

h. Catkins naked, very slender; fruit an acorn $(O a k)$.

i. Leaves entire. Shingle OAK, QUERCUS IMBRICARIA.

i. Leaves conspicuously lobed or toothed.

j. Leaf lobes not bristle-pointed; acorns maturing the first year.

k. Leaves deeply lobed.

1. Leaves regularly and narrowly lobed, smooth; bark gray, somewhat scaly.

White OAK, QUERCUS ALBA (p. 50).

1. Leaves irregularly and broadly lobed, finely pubescent beneath; bark gray.

Post OAK, QUERCUS STELLATA (p. 50).

1. Leaves irregularly lobed; bark black, furrowed; upper cup scales awned, making a fringe.

BUR OAK, QUERCUS MACROCARPA (p. 50).

k. Leaves slightly lobed or merely toothed.

1. Fruit long-stalked; leaves downy beneath; bark scaly.

SWAMP White OAK, QUERCUS BICOLOR (p. 50).

1. Fruit short-stalked; leaves regularly and many toothed. CHestinur OAKS, QUERCUS MUHLENBERGII and Q. PRINUS (p. 50, 5 I).

j. Leaf lobes bristle-pointed; acorns maturing the second year; bark dark, smooth above, furrowed below.

k. Cup scales loosely imbricated; inner bark yellow to orange.

k. Cup scales closely appressed.

Black OAK, QUERCUS VELUTINA (p. 52 ).

1. Leaves not deeply pinnatifid; acorns $2-3 \mathrm{~cm}$. long, less than a third being covered by the flat saucer-shaped cups.

RED OAK, QUERCUS RUBRA (p. 5I).

1. Leaves deeply pinnatifid; acorns less than $2 \mathrm{~cm}$. long; cups saucer-shaped. PIN OAK, QUERCUS PALUSTRIS (p. 5i).

1. Leaves deeply pinnatifid, shiny above; acorns more than halfcovered by the top-shaped or hemispherical cups.

Scarlet OAK, QUERCUS COCCINEA (p. 52 ).

h. Catkins with conspicuous scales, not very slender; fruit not an acorn.

i. Bark close, smooth and gray; stems angular.

Water Beech, CARPINUS Caroliniana (p. 48 ).

i. Bark rough below, smooth and brown above.

Hop Hornbeam, OSTRYA VIRGINIANA (p. 47).

g. Leaves compound (Walnut family).

h. Stamens more than ten; petals four; fruit indehiscent (Walnut).

i. Bark black, furrowed, rough; fruit spherical.

Black Walnut, JUGLaNs NIGRA (p. 46).

i. Bark with light-colored flattened ridges; fruit ellipsoid.

Butternut, JUGLANS CINEREA (p. 46).

h. Stamens ten or less; petals none; fruit dehiscent (Hickory).

i. Bark shaggy; husk thick; seed sweet.

Shag-bark Hickory, CARYA OVATA (p. 46 ).

i. Bark not exfoliating; husk thin; seed bitter. 
j. Leaflets 5-7; buds short-pointed, brownish; nut with thick and bony shell.

Pignut Hickory, CARYA GLABRA (p. 47).

j. Leaflets $7-11$; buds long-pointed, yellow; nut with thin-walled shell.

BitTernut Hickory, CARYA CORDIFORMIS (p. 47).

d. Flowers not in catkins.

o. Flowers small, usually greenish; corolla inconspicuous or wanting.

f. Flowers appearing decidedly before the leaves $(E l m)$.

g. Buds with rusty pubescence; bark aromatic; flowers nearly sessile; fruit orbicular, not ciliate: leaves rough above.

Slippery Elm, ULMUS FULVA (p. 52).

g. Buds glabrous; inner bark not aromatic; flowers on slender drooping pedicels; fruit ovate, ciliate; leaves smoothish above.

White ElM, ULMUS AMERICANA (p. 52).

f. Flowers appearing with or after the leaves.

g. Flowers in dense heads, monoecious; leaves palmately lobed.

g. Flowers not in dense heads.

SYCAMORE, PLATANUS OCCIDENTAIIS (p. 76 ).

h. Leaves compound; trees thorny; fruit a large flat pod.

h. Leaves simple.

HoNEY Locust, GLEDITSIA TRIACANTHOS (p. 82).

i. Young bark green, aromatic; flowers dioecious.

i. Bark not aromatic.

SASSAFRAS VARIIFOLIUM (p. 68).

j. Old bark remaining smooth, gray.

j. Old bark rough.

BEECH, FAGUS GRANDIFOLIA (p. 50).

k. Bark with corky warts; leaves oblique at base.

HACKBERRY, CELTIS OCCIDENTALIS (p. 53).

k. Bark furrowed, often divided into square plates. ("alligator bark"); leaves acute at base. Sour GuM, NYSSA SYLVATICA (p. IoI).

๑. Flowers with conspicuous and usually showy corollas.

f. Flowers irregular (papilionaceous); fruit a pod, leguminosae.

g. Leaves simple, heart-shaped; flowers red-purple.

REDBud, CERCIS CANADENSIS (p. 82).

g. Leaves compound; flowers white; plant spiny.

Black Locust, ROBINIA PSEUdACACIA (p. 84).

f. Flowers regular.

g. Petals brown-purple. PAPAw, ASIMINA TRILOBA (p. 66).

g. Petals greenish-yellow to cream color.

h. Sepals and petals five; pistil single; ovary five-celled; leaves heartshaped.

BAsswOod, TILIA AMERICANA (p. 93).

h. Sepals three; petals six or more; pistils many, cohering in a cone (Magnolia family).

i. Leaves pointed. Cucumber Tree, Magnolia ACUMinata (p. 65).

i. Leaves truncated above.

g. Petals pink.

TULIP TREE, LIRIODENDRON TULIPIFERA (p. 65).

g. Petals white (Rosaceae).

h. Leaves compound. Mountain Ash, PYRUS AMERICANA (p. 77).

h. Leaves simple.

i. Ovary one-celled (Prunus).

j. Flowers racemose.

k. Leaves oblong, shiny, crenate-serrulate, the teeth incurved; lenticels 
horizontal. Wild Black CherRy, PRUNUS SEROTINA (p. 80).

k. Leaves obovate, sharply serrate, the teeth spreading; lenticels small, round. CHOKE CHERRY, PRUNUS VIRGINIANA (p. 80).

j. Flowers umbellate.

k. Bark red-brown; plant not spiny; flowers small (petals $6 \mathrm{~mm}$. or less in length), appearing with the leaves.

Wild Red Cherry, PRUNUS PENNSyivanica (p. 8o).

k. Bark black; plant spiny; flowers large (petals $8 \mathrm{~mm}$. or more in length), appearing before the leaves.

Wild Plum, PRUNUS AMERICANA (p. 80).

i. Ovary two-five-celled.

j. Branches spring. Hawthorn, CRATAEgUS (many species). (p. 77.)

j. Branches not spiny.

Serviceberry, AMELANCHIER CANADENSIS (p. 77).

a. SHRUBS (including woody vines). (p. 14).

b. Climbing shrubs (lianas).

c. Twiners.

d. Leaves opposite; corolla sympetalous, irregular.

HoNeYSUCKLE, LONICERA DIOICA (p. II8).

d. Leaves not opposite; corolla polypetalous, regular.

Bittersweet, CELASTRUS SCANDENS (p. 9o).

c. Plants climbing by tendrils; bark shreddy; leaves heart-shaped; flowers inconspicuous, fragrant (Grape).

d. Lower leaf surface woolly or tomentose.

e. Each of several successive leaves opposite a tendril or an inflorescence.

Fox Grape, VITIS LABRUSCA (p. 92).

e. Every third leaf not opposite a tendril or an inflorescence.

Summer Grape, VITIS AESTIVAIIS (p. 92).

d. Lower leaf surface smooth or merely pubescent.

River Grape, VITIS VULPINA (p. 93).

b. Erect or prostrate shrubs, not climbing.

c. Evergreens with tough and leathery leaves (p. Io).

d. Leaves very narrow, mostly awl- or needle-shaped, not white beneath.

e. Flowers yellow, showy, not in catkins; leaves minute.

e. Flowers inconspicuous or in catkins: leaves not minute.

HUDSONIA TOMENTOSA (p. 94).

f. Leaves three in a cluster.

Pitch Pine, PINUS RIgida (p. 31 ).

f. Leaves single.

g. Leaves in whorls of three, sharp-pointed, whitish above.

JUNIPER, JUNIPERUS COMMUNIS (p. 32).

g. Leaves scattered, blunt, green on both surfaces.

YEW, TAXUS CANADENSIS (p 30).

d. Leaves narrowly oblong or broader (rather narrow and white beneath in Andromeda); flowers showy.

e. Leaves compound; bristly, tailing shrub. RUBUS HISPIDUS (p. 8I).

e. Leaves simple (Heath family).

f. Stems erect.

g. Leaves conspicuously hairy beneath; stamens five to seven; petals nearly separate. LABRAdur TEA, LEDUM GROENLANDICUM (p. ror).

g. Leaves smooth or but slightly hairy beneath; stamens ten; corolla distinctly sympetalous.

h. Corolla cylindrical or bell-shaped.

i. Leaves glaucous whitish beneath. 
BOG ROSEMARY, ANDROMEDA GLAUCOPHYLLA (p. I02).

i. Leaves yellowish-green, brown scurfy beneath.

Leather Leaf, CHAMAEDAPHNE CALYCULATA (p. 102).

h. Corolla wheel-shaped; anthers embedded in corolla pouches; leaves dark green.

f. Stems prostrate.

g. Stems distinctly woody; leaves obovate, smooth; flowers not fragrant.

BEARBERRY, ARCTOSTAPHYLOS UVA-URSI (p. I03).

g. Stems but slightly woody; leaves heart-shaped, hairy; flowers fragrant.

Trailing ARButus, EPIgAEA REPENS (p. I03).

c. Plants with periodically deciduous leaves, which usually are not tough and leathery.

d. Branches and leaves opposite (p. II).

e. Leaves compound.

f. Flowers drooping, polypetalous; bark striped.

BladDER Nut, STAPHYLEA TRIFOLIA (p. 91).

f. Flowers in pyramidal cymes, sympetalous.

RED-BERRIED Elder, SAMBUCUS RACEMOSA (p. 120).

e. Leaves simple.

f. Corolla wanting; flowers yellow; leaves scurfy.

f. Corolla present.

SHEPHERDIA CANADENSIS (p. 97).

g. Corolla polypetalous.

h. Flowers perigynous (Euonymus).

i. Erect shrub; leaves petioled; corollas dark purple, commonly fourparted.

WAAHOO, EUONYMUS ATROPURPUREUS (p. 90).

i. Trailing shrub, rooting freely; leaves nearly sessile; corollas greenishpurple, commonly five-parted.

STRAWBERRY BUSH, EUONYMUS AMERICANUS OBOVATUS.

h. Flowers epigynous (Dogwood).

i. Corollas greenish, surrounded by a showy white involucre.

FLOWERING DOGWOOD, CORNUS FLORIDA (p. IOO).

i. Corollas white; involucre wanting.

j. Branches red-purple; leaves short-pointed; cymes flat.

RED-OSIER DOGWOOD, CORNUS STOLONIFERA (p. IOo).

j. Branches grayish brown; leaves taper-pointed; cymes convex.

Panicled Dogwood, Cornus Paniculata (p. roo).

g. Corolla sympetalous (Honeysuckle family).

h. Corolla wheel-shaped, spreading (Viburnum).

i. Leaves palmately veined (three-ribbed), somewhat three-lobed.

Maple-leaved Viburnum, VIBURNUM ACERIfolium (p. II9).

i. Leaves pinnately veined.

j. Leaves pubescent, heart-shaped, coarsely toothed; petioles very short.

ARROW-WOOD, VIBURNUM PUBESCENS (p. I19).

j. Leaves smooth, acute at base, finely toothed; petioles prominent.

k. Branches obliquely ascending; young leaves and petioles greenish.

Black Haw, VIBURNUM LENTAGO (p. II9).

k. Branches nearly or quite horizontal; young leaves and petioles reddish. BLACK HAw, VIBURNUM PRUNIFOLIUM (p. 120).

h. Corolla tubular or bell-shaped.

i. Corolla bell-shaped, regular, pink.

SNOWBERRY, SYMPHORICARPUS RACEMOSUS (p. I18).

i. Corolla tubular, more or less irregular, yellow or yellowish. 
j. Calyx tube tapering, lobes slender, awl-shaped.

Bush Honeysuckle, DIERVILIA LONICERA (p. II7).

j. Calyx tube not tapering, lobes minute.

Fly Honeysuckle, LONICERA CANADENSIS (p. ii ).

d. Branches and leaves not opposite.

e. Flowers monoecious or dioecious, one or both sorts in catkins.

f. Plants with resinous-dotted, fragrant leaves (Myrica).

g. Leaves entire or slightly toothed.

BAyberry, MYRICA CAROLINENSIS (p. 45).

g. Leaves pinnatifid. SweEt Fern, MYRICA ASPLENIFOLIA (p. 45).

f. Plants without resinous-dotted, fragrant leaves.

g. Flowers appearing decidedly before the leaves.

h. Flowers dioecious.

i. Winter buds with one scale; catkin scales entire or nearly so (Pussy willow).

j. Capsules glabrous.

j. Capsules pubescent.

SAIIX CORDATA, etc. (p. 43).

SAIIX DISCOLOR, etc. (p. 43).

i. Winter buds with several scales; catkin scales lacerate.

h. Flowers monoecious.

ASPEN, POPULUS TREMULOIDES (p. 44).

i. Both sorts of flowers conspicuously in catkins (Alder).

j. Leaves doubly serrate, rounded at base, usually downy.

HoAry Alder, ALNUS INCANA (p. 49).

j. Leaves regularly serrate, acute at base, usually smooth.

Smooth Alder, ALNUS RUGOSA (p. 49).

i. Only the staminate flowers conspicuously in catkins.

HAZEL, CORYLUS AMERICANA (p. 47).

g. Flowers appearing with or after the leaves.

h. Both sorts of flowers conspicuously in catkins.

1. Flowers dioecious.

LoNG-LEAVEd Willow, SAIIX LONGIFOLIA (p. 43).

i. Flowers 'monoecious (Birch).

j. Bark dull white, not readily exfoliating; leaves triangular, long taper-pointed. GRAy BIRch, BETULA POPUIfFOLIA (p. 49).

j. Bark creamy white, exfoliating readily; leaves not triangular nor taper-pointed. PAPER BIRCH, BETULA ALBA PAPYRIFERA (p. 49).

h. Only the staminate flowers conspicuously in catkins.

i. Bark close, smooth and gray; stems angular.

Water BeEch, CaRPINUS CAROLINIANA (p. 48 ).

i. Bark rough below, smooth and brown above.

Hop Hornbeam, OSTRYA VIRGINIANA (p. 47).

e. Flowers not in catkins.

f. Only one perianth whorl present; flowers appearing before or with the leaves (p. 12).

g. Bark leathery, not aromatic.

g. Bark aromatic.

Leatherwood, Dirca PALUStris (p. 96).

h. Plant prickly.

PRICKLy ASH, ZANTHOXYLUM AMERICANUM (p. 87).

h. Plant not prickly.

i. Flowers conspicuously stalked. SASSAFRAS VARIIFOLIUM (p. 68).

i. Flowers in almost sessile clusters.

Spice Bush, BENZOIN AESTIVALE (p. 68). 
f. Calyx and corolla both present.

g. Corolla sympetalous (Heath family).

h. Flowers hypogynous (Rhododendron).

i. Flowers pink, appearing before the leaves; not clammy pubescent.

Purple Azalea, RHOdOdENDRON NUDIflorUM (p. 102).

i. Flowers white, appearing after the leaves, clammy pubescent.

SWAMP HONEYSUCKLE, RHODODENDRON VISCOSUM (p. ro1).

h. Flowers epigynous.

i. Flowers reddish; bark brownish or reddish, not warty; leaves resinous. HuCKLEBERKY, GAYLUSSACIA BACCATA (p. ro3).

i. Flowers whitish to greenish; bark warty; leaves not resinous (Blueberry).

j. Bog shrubs, over one. meter in height.

SWAMP BLUEBERry, VACCINIUM CORYMBOSUM (p. ro4).

j. Upland shrubs, less than one meter in height.

k. Stems dwarf (2-6 dm.), green, spreading; leaves serrulate with bristle-pointed teeth, bright green.

LOW BLUEBERRY, VACCINIUM PENNSYLVANICUM (p. 104).

k. Stems low $(3-9 \mathrm{dm}$.$) , yellowish green, erect; leaves pale at least$ beneath, entire or nearly so. VACCINIUM VACILLANS (p. 104).

g. Corolla polypetalous.

h. Plants armed with spines, prickles, or bristles (p. 13).

i. Leaves compound (p. 13).

j. Petals and stamens six. BARBERRY, BERBERIS VULGARIS (p. 67).

j. Petals five; stamens numerous (Rosaceae).

k. Pistils freely exposed (Rubus). •

1. Erect or arched-ascending shrubs.

m. Stems angular, armed with stout prickles; bristles wanting; leaves palmately $3-5$ foliolate; flowers large $(2-5 \mathrm{~cm}$. or more in width). TALL BLACKBERRY, RUBUS ALIEGHENIENSIS (p. 8r).

m. Stems round, armed with bristles; leaves pinnately $3-5$ foliolate; flowers small $(2.5 \mathrm{~cm}$. or less in width).

n. Stems erect, slightly if at all glaucous, densely bristlecovered; petals as long as the sepals.

RED RASPBERry, RUBUS IDAEUS ACULEATISSIMUS (p. 8o).

n. Stems recurved, rooting at the tips, conspicuously glaucous; petals shorter than the sepals.

Black RAspberRy, RUBUS OCCIDENTALIS (p. 81 ).

1. Trailing shrubs.

$\mathrm{m}$. Leaves leathery, shiny, tending to be evergreen; flowers $2 \mathrm{~cm}$. or less in width.

RUBUS HISPIDUS (p. $8 \mathrm{r}$ ).

m. Leaves not leathery nor shiny, strictly deciduous; flowers $2 \mathrm{~cm}$. or more in width. DEWBERRY, RUBUS VILLOSUS (p. 8I).

k. Pistils enclosed in the fleshy calyx tube (Rose).

1. Pedicels and receptacles naked; sepals connivent after flowering, persistent; true prickles wanting; bristles present.

Wild Rose, ROSA BLANDA (p. 79).

1. Pedicels and receptacles hispid; sepals spreading after flowering, deciduous; prickles regularly present.

m. Swamp shrubs with serrulate leaves; stipules narrowly linear.

Swamp Rose, ROSA CaRolina (p. 79).

m. Upland shrubs with coarsely serrate leaves; stipules oblanceolate.

PAsture Rose, ROSA HUMILIS (p. 79). 
1. Leaves simple.

j. Flowers pink. WILD CRAB, PYRUS CORONARIA (p. 77).

j. Flowers white.

k. Ovary one-celled. Wild Plum, PRUNUS Americana (p. 8o).

k. Ovary $2-5$ celled.

HAWTHORN, CRATAEgUS (many species) (p. 77).

j. Flowers yellow or yellowish-green.

k. Leaves pinnately veined.

k. Leaves palmately veined (Gooseberry).

BARBERRY, BERBERIS VULGARIS (p. 67).

1. Ovaries and fruits bristly; calyx lobes decidedly shorter than the tube; leaves pubescent.

RIBES CYNOSBATI (p. 75).

1. Ovaries and fruits smooth; calyx lobes as long as or longer than tube; leaves smoothish. RIBES OXYACANTHOIDES (p. 75 ):

h. Plants unarmed.

i. Leaves compound.

j. Leaves trifoliolate.

k. Flowers appearing decidedly before the leaves; leaves rounded, toothed. Fragrant Sumac, RHUS CANADENSIs (p. 89 ).

k. Flowers appearing after the leaves; leaves pointed, entirc,

Hop TREe, PTELEA TRIfoliata (p/87).

j. Leaves pinnate.

k. Stipules free from the petiole.

Mountain Ash, PYRUS AMERICANa (p. 77).

k. Stipules adnate to the petiole.

WiLd Rose, ROSA BLANDA (p. 79).

i. Leaves simple.

j. Petals six, brown purple; sepals three.

PAPAW, ASIMINA TRILOBA (p. 66).

j. Petals five, rose purple or red-purple; sepals five-parted.

k. Flowers appearing decidedly before the leaves; corolla irregular. REDBUD, CERCIS CANADENSIS (p. 82).

k. Flowers appearing after the leaves; corolla regular.

ROSE-FLOWERING RASPBERRY, RUBUG ODORATUS (p. 8x).

j. Petals greenish or yellowish.

k. Leaves palmately veined.

Wild Black Currant, RIBES Floridum (p. 75).

k. Leaves pinnately veined (Holly family).

1. Petals oval to obovate, adnate to the stamens.

WINTERBERRY, ILEX VERTICILLATA (p. 89).

1. Petals linear, free from the stamens.

Mountain Holly, NEMOPANTHUS MUCRONATA (p. 89).

j. Petals white.

k. Stamens four; calyx four-parted.

Alternate-leaved Dogwood, Cornus alternifolia (p. ioo).

k. Stamens fifteen or more; calyx five-parted (Rosaceae).

1. Stamens 15-20; pistil solitary (Prunus).

m. Flowers racemose, appearing after the leaves.

CHOKEBERRY, PRUNUS VIRGINIANA (p. 8o).

m. Flowers umbellate, appearing before or with the leaves.

n. Flowers appearing with the leaves; bark red-brown; distinctly tree-like in habit, with a conspicuous primary trunk.

Wild Red CherRy, PRUNUS PENNSYIVANICA (p. 80). 
n. Flowers appearing before the leaves; the same root producing several to many shoots.

Sand Cherry, PRUNUS PUMILA (p. 8o).

1. Stamens more than twenty; carpels two to five.

m. Leaves palmately veined.

NINE-BARK, PHYSOCARPUS OPULIFOLIUS (p. 76).

m. Leaves pinnately veined.

n. Flowers cymose. ChOKEBERr, PYRUS ARBUTIFOLIA (p. 77).

n. Flowers racemose.

SERVICEBERRY, AMELANCHIER CANADENSIS (p. 77).

\section{a. HERBS.}

b. Fern-like or rush-like plants without seeds or true flowers.

c. Spores borne on brownish stems, the green organs borne on separate stems, appearing later.

Field Horsetail, EQUisetum ARVENSE (p. 30).

c. Spores and foliage organs not borne on separate stems (Osmunda).

d. Spores borne on separate leaves, which arise from the same stem as the green leaves. Cinnamon FERn, OSMUNDA CINNAMOMEA (p. 29 ).

d. Spores borne on special portions of leaves which otherwise are green.

e. Spore-bearing portion terminal.

e. Spore-bearing portion median.

Royal FERN, OSMUNDA REGAIIS (p. 29).

INTERRUPTED FERN, OSMUNDA CLAYTONIANA (p. 29).

b. Plants with true flowers and seeds.

c. Stems with vascular bundles scattered irregularly throughout (as seen in cross section) without a vascular ring between two areas without bundles, viz., the pith and bark; leaves unless long and narrow with two or more primary veins (except in Symplocarpus), which are approximately parallel, or at least not divergent above (except in Trillium and Arisaema); smaller veins not conspicuously reticulated (except in Trillium, Arisaema, and Symplocarpus); floral parts in threes or sixes (except in Maianthemum and Symplocarpus, where they are in fours, in Arisaema, where the perianth is wanting, and in Sparganium, where the perianth number varies.) (Monocotyledons.) (p. I6.)

d. Flowers in dense heads or spikes: perianth inconspicuous.

e. Flowers in heads, not enclosed in a spathe.

BUR REED, SPARGANIUM EURYCARPUM (p. 32).

e. Flowers in spike (spadix); if in head, enclosed in a spathe. (Araceae.)

f. Spadix freely exposed, not enclosed in a spathe.

f. Spadix enclosed in a spathe.

SWeEt Flag, ACORUS CALAmUS (p. 34).

g. Spadix cylindric or club-shaped, the upper portion flowerless; flowers imperfect, appearing with the leaves.

JACK-IN-THE-PULPIT, ARISAEMA TRIPHYLLUM (p. 33).

g. Spadix globose, flower-bearing to the summit; flowers perfect, appearing before the leaves.

SkUnK Cabbage, SYMPLOCARPUS Foetidus (p. 33 ).

d. Flowers not in dense heads or spikes; perianth commonly showy.

e. Floral parts in fours.

Wild Lily-of-the-valley, MAIANThemUM CANADENSE (p. 37).

e. Floral parts in threes or sixes.

f. Perianth distinctly differentiated in color into a calyx and corolla (p. 15). g. Leaves linear to lanceolate, not whorled.

SPIDERWORT, TRADESCANTIA VIRGINICA (p. 34). 
g. Leaves lanceolate or broader, in whorls of three (Trillium).

h. Flower sessile.

i. Leaves sessile; sepals spreading; petals dull purple to greenish.

TRILLIUM SESSILE (p. 39).

i. Leaves petioled; sepals reflexed; petals dark purple.

TRILLIUM RECURVATUM (p. 39).

h. Flower pedicelled.

i. Petals ovate to lanceolate, brown purple (or white or greenish); stigmas stout and spreading or recurved; flowers ill-scented.

TRILIIUM ERECTUM (p. 39).

i. Petals oblanceolate, white; stigmas slender, erect or nearly so.

TRILLIUM GRANDIFLORUM (p. 40).

1. Perianth lobes approximately similar in color and ctherwise.

g. Flowers hypogynous (Lily family). (p. 16.)

h. Flowers green or greenish.

i. Flowers perfect.

j. Leaves in whorls.

Cucumber Root, MEDEola VIRGiniaNa (p. 38 ).

j. Leaves not in whorls.

k. Flowers terminal, solitary or in umbels; perianth segments distinct. DISPORUM LANUGINOSUM (p. 38).

k. Flowers axillary; perianth segments not distinct (Solomon's seal).

1. Leaves minutely pubescent and glaucous beneath, nearly sessile; peduncles $\mathrm{I}-3$ flowered; perianth $10-12 \mathrm{~mm}$. long; filaments papillose roughened. . POLYGONATUM BIFLORUM (p. 38).

1. Leaves glabrous, partly clasping; peduncles 2-8 flowered; perianth I2-20 mm. long; filaments smooth or nearly so.

POLYGONATUM COMMUTATUM (p. $\left.3^{8}\right)$.

i. Flowers not perfect.

j. Flowers polygamo-monoecious.

False Hellebore, VERatrum Viride (p. 34).

j. Flowers dioecious. Carrion Flower, SMilaX HERBACEA (p. 40).

h. Flowers yellow or yellowish.

i. Leaves radical. Yellow Adder's Tongue Lily,

ERYTHRONIUM AMERICANUM (p. 36).

i. Leaves whorled. Cucumber Root, MEDEOLA VIRGINIANA (p. 38 ).

i. Leaves cauline but not whorled.

j. Leaves perfoliate (Bellwort).

k. Leaves glaucous and glabrous; perianth granular pubescent within; stamens shorter than the styles. UVULARIA PERFOLIATA (p. 35).

k. Leaves pubescent beneath, not glaucous; perianth smooth or nearly so; stamens exceeding the styles.

UVULARIA GRANDIFLORA (p. 35).

j. Leaves sessile.

k. Stem angled, smooth.

k. Stem round, hairy.

OAKESIA SESSILIFOLIA (p. 35). DISPORUM LANUGINOSUM (p. $3^{8}$ ).

h. Flowers white or whitish.

i. Flowers large, solitary. White Adder's Tongue Lily,

ERYTHRONIUM ALBIDUM (p. 36).

i. Flowers small, disposed in racemes or panicles (False Solomon's seal).

j. Flowers in panicles; pedicels very short; stamens exceeding the perianth segments which are about $2 \mathrm{~mm}$. long; leaves downy.

SMILACINA RACEMOSA (p. 36). 
j. Flowers in racemes; pedicels elongated; perianth segments 4-5 mm. long; stamens included; leaves glabrous.

SMILACINA STELLATA (p. 37).

h. Flowers pink. Wild Garlic, ALLIUM CANADENSE (p. 35).

h. Flowers blue. Wild Hyacinth, Camassia esculenta (p. 36).

g. Flowers epigynous.

h. Flowers yellow. Yellow-eyed Grass, HYPOXIS HIRSUTA (p. 41).

h. Flowers blue or white (Iris family).

i. Stigmas petal-like.

Blue Flag, iris VERsicolor (p. 41).

i. Stigmas thread-like.

BLUE-EYED GRASS, SISYRINCHIUM ANGUSTIFOLIUM (p. 41).

c. Stems commonly with a vascular ring between two areas without vascular bundles, viz., the pith and bark; leaves with but one primary vein or with two or more strongly divergent primary veins; smaller veins commonly conspicuously reticulated (Dicotyledons).

d. Perianth none, though the corolla-like involucre may readily be mistaken for a perianth; stems with milky juice and crowded linear leaves.

CyPRESS SPURge, EUPHORBIA CYPARISSIAS (p. 88).

d. Perianth present; stems never with both milky juice and crowded linear leaves.

e. Only one perianth whorl present (usually arbitrarily called the calyx, except in the Umbelliferae); flowers not in dense heads (p. 17).

f. Flowers hypogynous (p. 17).

g. Pistil one.

h. Flowers dioecious: stems with sheathing stipules.

Field Sorrel, RUMEX ACETOSELLA (p. 55).

h. Flowers perfect; stipules wanting.

PePPERgRass, LEPIDIUM APETALUM (p. 71).

g. Pistils more than one; stipules if present not sheathing the stem (Ranunculaceae).

h. Flowers dioecious.

h. Flowers perfect.

Early Meadow Rue, Thalictrum DiotCum (p. 6o).

i. Ovaries with but one ovule; involucre present.

j. Leaves compound.

k. Roots tuberous; flowers several in an umbel.

Rue ANEMONe, ANEMONELLA THALICTROIDES (p. 61).

k. Roots filamentous; flower single.

WOOD ANEMONE, ANEMONE QUINQUEFOLIA (p. 62).

j. Leaves simple.

k. Flowers appearing before the leaves of the season (old leaves persisting over winter); leaves three-lobed (Hepatica).

1. Leaf lobes rounded.

HEPATICA TRILOBA (p. 61).

1. Leaf lobes pointed. HEPATICA ACUTILOBA (p. 61).

k. Flowers appearing after the leaves; leaves cleft.

ANEMONE CANADENSIS (p. 62).

1. Ovaries with two or more ovules; involucre wanting.

j. Flowers yellow; leaves simple.

j. Flowers white.

Marsh Marigold, CaItha PaIUStris (p. 62).

k. Leaves decompound.

ISOPYRUM BITERNATUM (p. 62).

k. Leaves tri-foliolate. If the small club-shaped petals are overlooked, there may be sought here 
f. Flowers epigynous.

GoldTHREA, COPTIS TRIFOLIA (p. 63).

g. Leaves simple; ovary not two-celled.

h. Leaves oblong; stem erect; calyx 5-lobed; ovary 1-celled.

Bastard Toadflax, ComandRa UMBellata (p. 54).

h. Leaves kidney-shaped; aerial stem wanting; calyx 3-lobed; ovary 6-celled. WILD GINGER, ASARUM CANADENSE (p. 55).

g. Leaves compound, ovary two-celled; flowers in umbels (Umbelliferae).

h. Flowers yellow.

i. Leaflets rounded.

i. Leaflets pointed.

TAENIDIA INTEGERRIMA (p. 99). ZIZIA AUREA (p. 99)

h. Flowers white.

i. Annual; stem low $(1.5-5 \mathrm{dm}$.); foliage light green; fruit narrowly oblong.

CHAEROPHYILUM PROCUMBENS (p. 98).

i. Perennials.

j. Stem low (1-2.5 dm.), arising from a corm; plant glabrous; flowers appearing in earliest spring, the red-brown stamens contrasting with the white petals.

HARBINGER-OF-SPRING, ERIGENIA BULBOSA (p. 98).

j. Plants of medium to tall stature ( $3 \mathrm{dm}$. or higher), not arising from corms; flowers appearing in middle or late spring; stamens not red-brown.

k. Leaves 3 -foliolate; leaflets large, ovate, doubly serrate; plants with unpleasant odor when bruised.

HONEWORT, CRYPTOTAENIA CANADENSIS (p. 99).

k. Leaves ternately decompound.

1. Coarse plant, 1-3 m. tall, pubescent; umbels large (more than ro $\mathrm{cm}$. in diameter); fruit obovate, nearly as broad as long.

Cow PARSNip, HERACLEUM LANATUM (p. 99).

1. Plant of medium size, $3^{-12} \mathrm{dm}$. in height; umbels small (less than $5 \mathrm{~cm}$. in diameter); fruit slender, much elongated (Sweet cicely).

m. Plant glabrous; root very aromatic; styles $2 \mathrm{~mm}$. or more in length.

OSMORHIZA LONGISTYLIS (p. 98).

m. Plant pubescent; root not very aromatic; styles not exceeding I mm. in length.

OSMORHIZA CLAYTONI (p. 98).

e. Both calyx and corolla present (except in soine Compositae, whose flowers are in dense heads).

f. Corolla polypetalous or nearly so (p. 24 ).

g. Flowers hypogynous or perigynous (p. 23).

h. Petals similar, leaf-like without tubular modifications (p. 22).

i. Pistils more than one, the carpels, however, often being more or less united (p. I9).

j. Flowers strictly hypogynous (stamens inserted on receptacle). (p. 18.)

k. Pistils united; stamens ten (Geranium).

1. Perennial; petals more than I $\mathrm{cm}$. long.

GERANIUM MACULATUM (p. 86).

1. Annual or biennial; petals less than $I \mathrm{~cm}$. long.

GERANIUM CAROLINIANUM (p. 86).

k. Pistils separate: stamens more than ten (Ranunculaceae).

1. Pistils with but one ovule. 
m. Flowers appearing after the leaves, the latter not persisting through the winter; flowers yellow (white in one species) (Buttercup).

n. Flowers white. White Water Buttercup,

RANUNCULUS AQUATILIS CAPILLACEUS (p. 59).

n. Flowers yellow.

o. Plant aquatic. Yellow Water Buttercur,

RANUNCULUS DELPHINIFOLIUS (p. 59).

o. Plant terrestrial.

p. Root leaves merely crenate, not divided; flowers small, inconspicuous. RANUNCULUS ABORTIVUS (p. 59).

p. Leaves conspicuously cleft or divided; flowers commonly large and showy.

q. Plant of dry hillsides, flowering in early spring; roots fleshy thickened. RANUNCULUS FASCICULARIS (p. 59).

q. Low plants of moist woods, flowering in middle or late spring.

r. Petals shorter than the reflexed calyx; carpels with long recurved beak. RANUNCULUS RECURVATUS (p. 59).

r. Petals much larger than the spreading calyx; carpels with straightish beak.

RANUNCULUS SEPTENTRIONALIS (p. 6o).

q. Introduced plants of fields and waysides; medium-sized to tall, erect plants.

r. Base of stem bulb-like; sepals reflexed.

RANUNCULUS BULBOSUS (p. 6o).

r. Base of stem not bulb-like; sepals spreading.

RANUNCULUS ACRIS (p. 6o).

m. Old leaves persistent through the winter, the flowers, which are white, pink, or blue, appearing before the new leaves. If the three-leaved involucre has been mistaken for a calyx, there may be sought here. HEPATICA (p. 6I). n. Leaf lobes rounded. HEPATICA TRILOBA (p. 6I). n. Leaf lobes pointed. HEPATICA ACUTILOBA (p. 6r).

1. Pistils with two or more ovules; leaves evergreen, tri-foliolate; flowers white; petals club-shaped; rootstocks bright yellow.

GoldthreAd, COYTIS TRIFOLIA (p. 63).

j. Flowers perigynous (stamens inserted on the calyx or corolla).

k. Leaves simple.

1. Stamens more than ten, coherent in a column; styles numerous; ovaries united in a ring.

Mallow, MaIVA ROTUNDifolia (p. 93).

1. Stamens ten or less, not coherent in a column; styles and carpels two (Saxifrage family).

m. Leaves not heart-shaped (Saxifrage).

n. Corolla white; calyx lobes not reflexed at maturity.

EARLY SAXIFRAGE, SAXIFRAGA VIRGINIENSIS (p. 74).

n. Corolla greenish; calyx lobes reflexed at maturity.

Swamp Saxifrage, SAXIFRAGA PENNSYLVANICA (p. 74).

m. Leaves heart-shaped.

n. Stamens five (Alum root).

o. Calyx regular.

o. Calyx oblique.

HEUCHERA AMERICANA (p. 74). HEUCHERA HISPIDA (p. 74). 
n. Stamens ten.

o. Stems with two opposite leaves; petals pinnatifid.

Bishop's CAP, MITELLA DIPHYLLA (p. 75).

0. Stems leafless, or if leafy, leaves not opposite; petals entire.

False Mitrewort, tiarella CORDifolia (p. 74).

k. Leaves compound.

1. Leaves without stipules; sepals, petals, and ovaries 3 .

False Mermaid, FloERKEa PROSERPINACOIDES (p. 88).

1. Leaves with stipules (Rose family).

m. Flowers yellow (Cinquefoil).

n. Leaves pinnate, white-tomentose beneath; perennial, spreading by runners. Silver Weed, POTENTILLA ANSERINA (p. 79).

n. Leaves palmate.

o. Annual or biennial with stout, erect stems; leaves 3 -foliolate. POTENTILLA MONSPELIENSIS (p. 78).

0. Perennials with procumbent stems.

p. Leaflets clearly five, white-woolly beneath.

Silvery Cinquefoil, POTENTILla ARGENTEA (p. 78).

p. Leaflets three, but appearing to be five by the division of the laterals; leaves pubescent, but not white-woolly beneath.

Common Cinquefoil, POTENTILLA CANAdENSIS (p. 79).

m. Flowers white.

n. Leaves all radical; propagating by leafless runners that root at the end; achenes exposed (Strawberry).

o. Achenes in pits; leaves moderately veiny.

Common Wild StrawberRy, FRAGARIA VIRgINIANA (p. 78).

o. Achenes superficial; leaves strongly veiny; a woodland plant.

Wood Strawberry, Fragaria VESCA (p. 78).

n. Plants with leafy stems; not propagating by leafless runners; achenes enclosed (Rubus).

o. Plants without prickles; leaves delicate, not evergreen.

DWARF RASPBERRY, RUBUS TRIFLORUS (p. 8I).

o. Plants with prickles; leaves leathery, tending to be evergreen.

RUBUS HISPIDUS (p. 8r).

i. Pistil only one, often more than one-celled, the carpels then being united into a compound pistil.

j. Aquatic plant; leaves large, floating; flowers yellow.

Yellow Pond Lily, NYMPHAEA ADVENA (p. 58).

j. Terrestrial plants.

k. Plants with colored juice.

1. Juice reddish orange: petals white.

BlOODROOT, SANGUINARIA CANADENSIS (p. 69).

1. Juice and petals yellow.

Celandine Poppy, STylophorUM DIPHYLlUM (p. 69).

k. Plants with watery juice.

1. Flowers yellow or yellowish (p. 20).

$m$. Some of the floral parts in fours or sixes (p. 20).

n. Sepals, petals, and stamens six.

Blue Cohosh, CAULOPHYLLUM THALICTROIDES (p. 67).

n. Sepals and petals four; stamens six (Crucifers).

o. Plant perennial, with lyrate root leaves, smooth.

WINTER-CRESS, BARBAREA VULGARIS (p. 72).

o. Plant annual, pubescent (Mustard). 
p. Pods $4 \mathrm{~cm}$. long, fully a third occupied by the prominent two-edged beak; leaves scarcely petioled.

ChARLOCK, BRASSICA ARVENSIS (p. $7 \mathrm{r}$ ).

p. Pods less than $2 \mathrm{~cm}$. long, with a very short beak; leaves slender petioled. Black Mustard, BRASSICA NIGRA (p. 72).

$m$. None of the floral parts in fours or sixes.

n. Stamens more than ten.

Frostweed, HELIANTHEMUM CANADENSE (p. 94).

n. Stamens ten.

o. Leaves simple, radical.

SWAMP SAXIFrage, SAXIFRAGA PENNSYIVANICA (p. 74).

o. Stems leafy; leaves tri-foliolate. LADY's SorReL,

OXALIS STRICTA and 0. CORNICULATA (p. 85).

n. Stamens five (Alum root).

o. Calyx regular.

o. Calyx oblique.

HEUCHERA AMERICANA (p. 74). HEUCHERA HISPIDA (p. 74).

1. Flowers not yellow.

m. Plants with opposite entire leaves.

n. Sepals two; leaves two; flowers pink.

SPRing BeAuty, CLAYTONIA VIRGINICA (p. 58).

n. Sepals four or five (Pink family).

o. Sepals distinct or nearly so.

p. Petals entire (Sandwort).

q. Leaves more than a centimeter long, obtuse.

ARENARIA IATERIFLORA (p. 56).

q. Leaves less than a centimeter long, acute.

ARENARIA SERPYLLIFOIIA (p. 56).

p. Petals notched or two-cleft.

q. Petals deeply two-cleft; styles $3-4$; stems hairy in lines.

ChickWeEd, STELLARIA MEDIA (p. 56).

q. Petals notched; styles five (Cerastium).

r. Stems annual; petals longer than the sepals; plant smoothish: pedicels and pods much elongated.

CERASTIUM NUTANS (p. 57).

r. Stems perennial; petals not longer than the sepals; plant clammy hairy; pedicels and pods short.

CERASTIUM VULGATUM (p. 57).

o. Sepals united; internodes glutinous.

Sleepy Catchfly, Silene ANTIRRhiNA (p. 57).

m. Plants without opposite leaves, or if opposite, not entire.

n. Petals white (p. 2i).

o. Stamens more than ten.

p. Leaves decompound; sepals four or five.

White BANEBerry, ACTAEA ALBA (p. 64).

p. Leaves simple, 5-9 parted; sepals six.

MAy APPLe, PODOPHYLLUM PELTATUM (p. 66).

o. Stamens ten (Saxifrage family).

p. Leaves not heart-shaped; ovary two-celled.

EARLy SAXifrage, SAXIFRAGA VIRGINIENSIS (p. 74).

p. Leaves heart-shaped; ovary one-celled.

q. Stems with two opposite leaves; petals pinnatifid.

Bishop's Cap, MITELLA DIPHYLLA (p. 75).

q. Stems leafless, or if leafy, leaves not opposite; petals entire. 
False Mitrewort, tiarella cordifolia (p. 74).

o. Stamens less than ten.

p. Sepals and petals three.

False Mermaid, FLOERKEA PROSERPINACOIDES (p. 88).

p. Sepals and petals four (Crucifers).

q. Plants more or less pubescent, some or all of the hairs being branched.

r. Pods triangular; root-leaves usually more or less pinnatifid; stem leaves arrow-shaped.

Shepherd's Purse, CAPSELLA BURSA-PASTORIS (p. 7 I).

r. Pods conspicuously elongated, not triangular.

s. Leaves mostly radical, oblong to obovate, entirc or nearly so. Whitlow Grass, DRABA CARoliniana (p. 7 i).

s. Radical leaves lyrate-pinnatifid; stem leaves present, though often few in number.

Rock CRESS, ARABIS IYRATA (p. 73).

q. Plants smooth, or if hairy, hairs simple.

r. Pods roundish; stamens two; some of the lower leaves pinnatifid. PEPPERGRAss, IEPIDIUM APETALUM (rarely), and I. VIRGINICUM (p. 7I).

r. Pods elongated; stamens six.

s. Leaves compound.

t. Leaves palmate (Toothwort).

u. Rootstock continuous; stem leaves two, 3 -foliolate.

DENTARIA DIPHYLLA (p. 72).

u. Rootstock separable into tubers; stem-leaves three, about five-cleft. DENTARIA LACINIATA (p. 72).

t. Leaves pinnate.

CARDAMINE PENNSYLVANICA (p. 73).

s. Leaves simple.

t. Underground stem tuberous; stem leaves petioled to sessile, not clasping.

Spring Cress, CARDaMine BULBOSA (p. 73).

t. Underground stem not tuberous; stem leaves arrowshaped, clasping.

ARABIS LAEVIGATA (p. 73).

n. Petals not white.

o. Sepals and petals in fours or sixes.

p. Sepals and petals in sixes; leaves compound; flowers greenish.

Blue Cohosh, CAULOPHYLLUM THALICTROIDES (p. 67).

p. Sepals and petals in fours (Crucifers).

q. Petals pinkish to purplish; stem leaves not clasping.

r. Underground stems tuberous; leaves entire or sparingly toothed.

SPRing Cress, CARDAMINE DOUGLASII (p. 73).

r. Underground stems not tuberous; leaves three-parted.

Toothwort, DENTARIA LACINIATA (p. 72).

q. Petals greenish; underground stems not tuberous; stem leaves arrow-shaped, clasping.

ARABIS IAEVIGATA (p. 73).

o. Sepals and petals in fives.

p. Leaves compound ( 3 -foliolate); underground stem bulbous (flowers pink to purple).

Violet WOOd SORREL, OXALIS VIOLACEA (p. 85). 
p. Leaves simple, though sometimes deeply cleft.

q. Leaves oblanceolate, not at all heart-shaped; petals greenish. SWAMP SAXIFRAGE, SAXIFRAGA PENNSYLVANICA (p. 74). q. Leaves more or less heart-shaped.

r. Stamens united in a column.

Common Mallow, MaLva Rotundifolia (p. 93). r. Stamens free.

s. Stamens five (Alum root).

t. Calyx regular. HEUCHERA AMERICANA (p. 74). t. Calyx oblique. HEUCHERA HISPIDA (p. 74).

s. Stamens ten (Geranium).

t. Perennials; petals more than $\mathrm{I} \mathrm{cm}$. long.

GERANIUM MACULATUM (p. 86).

t. Annuals or biennials; petals less than $I \mathrm{~cm}$. long.

GERANIUM CAROLINIANUM (p. 86).

h. Petals dissimilar in size or shape, or if similar, with more or less tubular modification.

i. Pistils more than one (Ranunculaceae).

j. Petals five, similar in size and shape, produced into large hollow spurs, scarlet (yellow within); pistils five; leaves ternately compound.

Columbine, AQUILEgIA CANADENSIS (p. 64).

j. Petals four, dissimilar, the upper pair with long spurs, blue; pistils three; leaves palmately divided or cut.

LARKSPUR, DELPHINIUM (p. 64).

i. Pistil only one.

j. Leaves simple, though sometimes lobed or divided (p. 23).

k. Flowers spiked; sepals five, dissimilar; petals three.

Seneca SNakeroot, POLYGala SENEgA (p. 87).

k. Flowers solitary; sepals five, auricled; petals five (Violet).

1. Plants without aerial stems.

m. Flowers blue.

n. Leaves conspicuously lobed or divided.

o. Rootstock erect; leaves 3 -divided, smoothish; leaf segments linear or nearly so.

Bird-Foot Violet, VIOLA PEDATA (p. 95).

o. Leaves palmately 5-9 lobed, pubescent; some leaf segments broader than linear.

VIOLA PALMATA (p. 95).

n. Leaves merely toothed above; basal portions lobed or not.

o. Leaves broad, heart-shaped, not at all lobed.

Common Blue Violet, Viola Cucullata (p. 95).

o. Leaves lanceolate or oblong lanceolate, incised or deeply toothed at base.

ArRow-leaved Violet, VIOLA SAgitTata (p. 95).

m. Flowers white with purple lines; rootstock slender.

n. Leaves heart-shaped.

n. Leaves lanceolate.

Common White Violet, Viola BLANDA (p. 95).

LANCE-Leaved Violet, VIOLA IANCEOLATA (p. 95).

1. Plants with aerial stems.

m. Flowers yellow; leaves pubescent.

Common Yellow Violet, Viola PUBEsCeNS (p. 95).

m. Flowers white or blue; leaves smooth or smoothish.

n. Stipules entire; spur short. VIOLA CANADENSIS (p. 95). 
n. Stipules fringed, toothed; spur at least twice as long as broad. VIOLA CONSPERSA (p. 96).

j. Leaves compound.

k. Leaves without stipules; sepals two; petals four, forming a heartshaped or spurred corolla; stamens six (Dicentra).

1. Underground stem a granulate bulb; corolla with two divergent spurs. Dutchman's Breeches, DICENTRA CUCULLARIA (p. 69).

1. Underground stem with scattered grain-like tubers; corolla heartshaped. SQUIRREL Corn, DICENTRA CANADENSIS (p. 70).

k. Leaves with stipules; sepals five, more or less united; petals five; stamens ten (Leguminosae).

1. Leaves 7-II foliolate; flowers purplish-blue.

1. Leaves 3 -foliolate.

COMMON LUPINE, LUPINUS PERENNIS (p. 82).

m. Flowers in heads (Clover).

n. Flowers sessile, red to rose-colored.

Red Clover, TRIFOLIUM PRATENSE (p. 83).

n. Flowers pedicelled; pedicels reflexed in age.

o. Plant creeping, the stems rooting freely; flowers white.

WhIte ClOVER, TRIFOLIUM REPENS (p. 83).

o. Stems ascending, not rooting; flowers pink.

Alsike Clover, TRIFOLIUM HYBRIDUM (p. 83).

m. Flowers in racemes (Sweet clover).

n. Flowers yellow.

Yellow SWeet Clover, MeIILOTUS OFficiNalis (p. 83 ).

n. Flowers white.

White Sweet Clover, melilotus AlBA (p. 84).

m. Flowers in spikes, yellow.

Black Medick, MEdicago LUPUlina (p. 84).

1. Leaves abruptly pinnate, terminated by a tendril; leaflets four or more.

m. Flowers small, a centimeter or less in length, white, tinged with blue. Wild Vetch, VICIA CAROLINIANA (p. 84).

m. Flowers more than a centimeter in length.

n. Flowers yellowish-white; leaflets $4^{-6 .}$

Wild Pea, LATHYRUS OCHROLEUCUS (p. 85 ).

n. Flowers purple or purplish; leaflets 6-14.

0. Peduncles $10-25$ flowered; leaflets $8-12$; stipules very small and slender. Wild PEA, LATHYRUS VENOSUS (p. 85).

o. Peduncles 2-8 flowered.

p. Leaflets 10-14; plants of upland woods and banks.

Wild Vetch, VICIA AMERICANA (p. 84).

p. Leaflets 4-8; plants of meadows and open swamps.

WiLd PeA, IATHYRUS PALUSTRIS (p. 85).

g. Flowers epigynous.

h. Sepals, petals, and stamens four; style one; flowers greenish, surrounded by a showy white involucre.

BUNCHBERRY, CORNUS CANADENSIS (p. IOO).

h. Sepals, petals, and stamens five: flowers in umbels.

i. Styles and carpels five; umbels two or more.

Wild Sarsaparilla, ARaIIa NUdicaulis (p. 97).

i. Styles and carpels three; umbel solitary (p. 24).

Dwarf Ginseng, PANAX Trifolium (p. 97). 
i. Styles and carpels two (Umbelliferae).

j. Petals yellow.

k. Leaflets serrate.

ZIZIA AUREA (p. 99).

k. Leaflets entire.

j. Petals white.

k. Annual; stem low ( $1.5-5 \mathrm{dm}$.); foliage light green; fruit narrowly oblong. CHAEROPHYLLUM PROCUMBENS (p. 98).

k. Perennials.

1. Stem low $(\mathrm{I}-2.5 \mathrm{dm}$.$) , arising from a corm; plant glabrous;$ flowers appearing in earliest spring, the red-brown anthers contrasting with the white petals.

HARBINGER-OF-SPRING, ERIGENIA BULBOSA (p. 98).

1. Plants of medium to tall stature ( $3 \mathrm{dm}$. or higher), not arising from corms; flowers appearing in middle or late spring; stamens not red-brown.

m. Leaves 3 -foliolate; leaflets large, ovate, doubly serrate; plants with unpleasant odor when bruised.

HONEWORT, CRYPTOTAENIA CANADENSIS (p. 99).

m. Leaves ternately decompound.

n. Coarse plant, I-3 m. tall, pubescent; umbels large (more than Io $\mathrm{cm}$. in diameter); fruit obovate, nearly as broad as long.

Cow PARSNip, HERACLEUM IANATUM (p. 99).

n. Plant of medium size, $3^{-12} \mathrm{dm}$. in height; umbels small (less than $5 \mathrm{~cm}$. in diameter); fruit slender, much elongated (Sweet cicely).

o. Plant glabrous; root very aromatic; styles $2 \mathrm{~mm}$. or more in length.

OSMORHIZA LONGISTYIIS (p. 98).

o. Plant pubescent; root not very aromatic; styles not exceeding I $\mathrm{mm}$. in length.

f. Corolla sympetalous.

OSMORHIZA CLAYTONI (p. 98).

g. Flowers hypogynous or perigynous (p. 28).

h. Corolla regular or nearly so, divisions similar size and shape (p. 26).

i. Leaves compound.

j. Leaves 3 -foliolate.

k. Marsh plants with white flowers; corolla bearded.

Buckbean, MENYANTHES TRIFOLIATA (p. 107).

k. Upland plants with pink to purple or yellow flowers (Oxalis).

1. Flowers yellow.

LAdY's SORREL, OXAIIS STRICTA and O. CORNICULATA (p. 85).

1. Flowers pink to purple.

Violet Wood Sorrel, OXAIIS VIOLACEA (p. 85).

j. Leaves pinnate; ovary three-celled.

POLEMONIUM REPTANS (p. Io8).

i. Leaves simple, though sometimes lobed or divided.

j. Leaves leathery, evergreen; flowers appearing before the new leaves.

Trailing ARbutus, EPIgaEa REPENS (p. I03).

j. Leaves not leathery; flowers appearing with or after the new leaves.

k. Leaves all radical (p. 25).

1. Flowers in dense, elongated spikes; stamens and parts of calyx and corolla in fours (Plantain).

m. Plant of woodland brooks and ravines, with smooth, heartshaped or round-ovate leaves.

PLANTAGO CORDATA (p. I I6). 
m. Plant of fields and waysides, with hairy lanceolate leaves.

Rib Grass, Plantago lanceolata (p. in6).

1. Flowers in umbels, nodding, very showy; corolla rose color to white. Shooting Star, DODECATHEON MEDIA (p. 105).

k. Leaves not all radical.

1. Some or all of the leaves opposite.

m. Ovary I-celled.

n. Swamp plant, the peduncles with a number of yellow flowers. TUFTED LOOSESTRIFE, LYSIMACHIA THYRSIFLORA (p. 104).

n. Woodland plant, with a solitary white flower, and a whorl of leaves at the summit of the stem.

Star Flower, TRIENTALIS AMERICANA (p. 105).

m. Ovary 2-celled (Veronica, whose flowers are nearly regular, may be sought here).

n. Annual with axillary, solitary white flowers.

Purslane Speedwell, Veronica PEREgrina (p. Ii 4 ).

n. Perennial.

o. Leaves pubescent, serrate; flowers pale blue, in axillary racemes.

Common Speedwell, VERoNica officinalis (p. II3).

o. Leaves smooth or smoothish, obscurely crenate; flowers white or pale blue with deeper stripes, in terminal racemes. ТнумЕLEAVED SPEEDWELL, VERONICA SERPYLIIFOLIA (p. 114).

m. Ovary 3-celled (Phlox).

n. Leaves linear; corolla lobes bifid. PHLOX BIFIDA (p. 108).

n. Leaves broader than linear, or if linear, corolla lobes not bifid.

o. Flowers in pyramidal or ellipsoid panicles; stems strictly erect.

p. Calyx teeth awn-pointed. PHLOX PANICULATA (p. I07).

p. Calyx teeth triangular lanceolate, scarcely pointed.

PHLOX MACULATA (p. Io7).

o. Flowers in simple or corymbed cymes.

p. Prostrate leafy shoots wanting; leaves linear to lanceolate.

PHLOX PILOSA (p. 107).

p. Plant with prostrate as well as ascending shoots; leaves lance oblong or broader. PHLOX DIVARICATA (p. 107).

1. None of the leaves opposite.

m. Ovary four-lobed (Boraginaceae) (p. 26).

n. Corolla reddish-purple; coarse pubescent herb.

HoUnd's TONGUE, CYNOGLOSSUM OFFICINALE (p. IOg).

n. Corolla white.

o. Inflorescence leafy-bracted only at the base.

o. Inflorescence leafy-bracted throughout.

MYOSOTIS VIRGINICA (p. IIo).

Corn Gromwell, IITHOSPERMUM ARVENSE (p. I10).

n. Corolla blue.

o. Corolla salver-form; slender, decumbent swamp plant.

FORGET-ME-NOT, MYOSOTIS LAXA (p. Iio).

o. Corolla trumpet-shaped; coarse woodland plant with showy flowers. Lungwort, MERTENSIA VIRGINICA (p. I1o).

n. Corolla yellow or orange (Puccoon).

o. Plant hispid; flowers peduncled; corolla bearded at the base within.

IITHOSPERMUM GMELINI (p. II1).

o. Plant soft pubescent; flowers sessile; corolla naked at the 
base within.

LITHOSPERMUM CANESCENS (p. III).

m. Ovary not four-lobed.

n. Ovary I-celled.

o. Leaves entire; style single.

Star Flower, Trientalis AMERICANA (p. 105).

o. Leaves cut-toothed or lobed; style two-cleft (Water-leaf).

p. Calyx with a reflexed lobe at each sinus; plant hairy.

HYDROPHYLLUM APPENDICULATUM (p. 109).

p. Calyx without a reflexed lobe at the sinus; plant smoothish.

q. Leaves pinnately divided; peduncles longer than the upper petioles. HYDROPHYLLUM VIRGINIANUM (p. 109).

q. Leaves palmately lobed; peduncles shorter than the petioles. HYDROPHYLLUM CANADENSE (p. I09).

n. Ovary 2-celled.

o. Low white-flowered annual of fields and waysides.

Purslane Speedwell, VERONICA PEREgRINA (p. 114 ).

o. Tall woodland perennial with blue flowets.

Nightshade, SOLANUM DULCAMARA (p. I12).

h. Corolla more or less irregular (zygomorphic), its divisions dissimilar in size or shape.

i. Plants without green leaves (Orobanchaceae).

j. Flowers numerous in a thick spike; stamens exserted.

CANCER-ROOT, CONOPHOLIS AMERICANA (p. II5).

j. Flowers solitary; stamens included.

BROOM-RAPE. OROBANCHE UNIFLORA (p. II5).

i. Plants with green leaves.

j. Leaves compound (p. 27).

k. Leaves without stipules.

1. Sepals two; corolla white, heart-shaped or spurred; stamens six (Dicentra).

m. Underground stem a granulate bulb; corolla with two divergent spurs. Dutchman's Breeches, DICENTRA CUCULLARIA (p. 69).

m. Underground stem with scattered grain-like tubers; corolla heartshaped. SQUirRel Corn, DICENTRA CANADENSIS (p. 70).

1. Sepals united, teeth inevident; corolla bilabiate; stamens four.

Lousewort, PEDICULARIS CANADENSIS (p. II4).

k. Leaves with stipules; calyx and corolla each with five parts; stamens ten (Leguminosae):

1. Leaves 7-II foliolate; flowers purplish-blue.

COMMON LUPINE, LUPINUS PERENNIS (p. 82).

1. Leaves 7-I I foliolate; flowers purplish-blue.

m. Flowers in heads (Clover).

n. Flowers sessile, red to rose-colored.

Red Clover, TRIfOLIUM PRATENSE (p. 83).

n. Flowers pedicelled, pedicels reflexed in age.

o. Plants creeping, the stems rooting freely; flowers white.

White Clover, TRIFOLIUM REPENS (p. 83).

o. Stems ascending, not rooting; flowers pink.

Alsike Clover, TRIFOLIUM HYBRIDUM (p. 83).

m. Flowers in racemes (Sweet clover) (p. 27).

n. Flowers yellow.

Yellow Sweet Clover, Melilotus OFficinalis (p. 83).

n. Flowers white. 
White SWeet Clover, MELIIOTUS ALBA (p. 84).

m. Flowers in spikes, yellow.

Black Medick, MEdicago IUPUliNa (p. 84).

1. Leaves abruptly pinnate, terminated by a tendril; leaflets four or more.

m. Flowers small, a centimeter or less in length, white, tinged with blue.

Wild Vetch, VICIA CAROLINIANA (p. 84).

m. Flowers more than a centimeter in length.

n. Flowers yellowish-white; leaflets 4-6.

Wild PEA, LATHYRUS OCHROLEUCUS (p. 85 ).

n. Flowers purple or purplish; leaflets 6-14.

o. Peduncles ro-25 flowered; leaflets 8-12; stipules very small and slender.

o. Peduncles 2-8 flowered.

p. Leaflets ro-r4; plants of upland woods and banks.

Wild VETCH, VICIA AMERICANA (p. 84).

p. Leaflets 4-8; plants of meadows and open swamps.

Wild Pea, LAThyRUS PAIUSTRIS (p. 85).

j. Leaves simple, though sometimes lobed or divided.

k. Ovary 4-lobed; leaves opposite (Mint family).

1. Leaves petioled; stamens four, the upper (inner) pair longer than the lower; plant creeping, strongly scented when bruised.

Ground Ivy, NEPETA HEDERACEA (p. IIr).

1. Upper leaves clasping; stamens four, the lower (outer) pair longer than the upper; plant decumbent.

k. Ovary 2-celled.

HENBIT, LAMIUM AMPLEXICAULE (p. 112).

1. Stamens six or eight; corolla three-parted; flowers white, in a close spike. Seneca Snakeroot, Polygala SENEga (p. 87).

1. Stamens two, four, or five (Scrophulariaceae).

m. Stamens two; corolla wheel-shaped or salver-shaped, almost regular (Veronica).

n. Annual, with axillary, solitary white flowers.

CoMmon SPEEdWELl, VERONICA OFFICINALIS (p. II3).

n. Perennial.

o. Leaves pubescent, serrate; flowers pale blue, in axillary racemes.

Purslane Speedwell, Veronica PEREgrina (p. II4).

o. Leaves smooth or smoothish, obscurely crenate; flowers white or pale blue with deeper stripes, in terminal racemes. ТнумЕ-

LEAVEd SPEEdWELl, VERONICA SERPYLLIFOLIA (p. I14).

m. Stamens four, or with a rudiment of a fifth.

n. Corolla spurred at base; at least the upper leaves not opposite (Toadflax).

o. Flowers yellow and orange.

0. Flowers blue.

Butter and Eggs, LINARIA VULGaris (p. i12).

n. Corolla not spurred at base.

o. Leaves opposite (p. 28).

p. Delicate annual with blue and white flowers.

Blue-eyed Mary, COLIINSIA VERNA (p. I13).

p. Coarse perennial with greenish-purple flowers.

FIgWORT, SCROPHULARIA MARILANDICA (p. II3). 
o. Leaves not opposite.

p. Upper leaves colored scarlet or yellow; stem leaves merely cleft. Painted Cup, CASTILLEJA COCCINEA (p. 114).

p. Upper leaves green; leaves pinnatifid.

LOUSEWORT, PEDICULARIS CANADENSIS (p. 114).

g. Flowers epigynous.

h. Flowers not grouped in dense heads.

i. Leaves whorled; stem weak, bristly.

i. Leaves opposite, not whorled.

Bedstraw, GaIIUM APARINE (p. I16).

j. Delicate plants without connate leaves (Houstonia).

k. Corolla salver-form; peduncles one-flowered.

Bluets, hoUStoNia caERULEA (p. i16).

k. Corolla funnel-form; peduncles more than one-flowered.

HOUSTONIA PURPUREA (p. II7).

j. Coarse plant; some leaves connate.

Horse GeNTIAN, TRIOSTEUM PERFOLIATUM (p. I18).

h. Flowers grouped in dense heads (Compositae); calyx where present represented by pappus.

i. Juice not milky.

j. Heads radiate (i. e., with ray flowers).

k: Rays flesh color to purplish, numerous; pappus capillary (Erigeron).

1. Plants with basal offsets; stem simple, not very leafy; heads large, few; rays about fifty.

ERIGERON PULCHELLUS (p. I 20).

1. Basal offsets none; stem corymbed, leafy; heads smallish, numerous; rays many more than fifty.

ERIGERON PHILADELPHICUS (p. I2I).

k. Rays white; pappus none.

1. Leaves compound, much dissected; heads small.

YARROW, ACHILLEA MILLEFOLIUM (p. 122).

1. Leaves simple, though sometimes pinnatifid; heads large. OX-EYE DAISY, CHRYSANTHEMUM IEUCANTHEMUM (p. I 23).

k. Rays yellow.

1. Leaves opposite; receptacle flat, chaffy; pappus two small teeth or none; rays few, lobed. COREOPSIS LANCEOLATA (p. 122).

1. Leaves not opposite.

m. Receptacle conical, chaffy; pappus none; plant rough hairy.

Black-eyed Susan, RUDBECkia Hirta (p. izi). m. Receptacle flat, not chaffy; pappus capillary; plant smoothish.

Golden RAGWORT, SENECIO AUREUS (p. 123).

j. Heads discoid (i. $e_{0}$, without ray flowers); dioecious plants with entire white-woolly leaves. Everlasting, ANTENNARIA (p. I2I).

i. Juice milky; flowers yellow.

j. Pappus of both scales and bristles (Krigia).

k. Annual; scales and bristles less than ten.

Dwarf Dandelion, KRIGIA VIRGINICA (p. 124).

k. Perennial; scales and bristles ten or more; stem leaves clasping.

KRIGIA AMPLEXICAULIS (p. 124).

j. Pappus all capillary; leaves radical, pinnatifid; achenes beaked.

DANDELION, TARAXACUM OFFICINAIE (p. 125). 


\section{DESCRIPTIVE FLORA}

OSMUNDACEAE (Flowering Fern Family)

Leafy plants with creeping rhizomes. Sporangia naked, globose, usually with pedicels. Stipes winged at the base.

\section{OSMUNDA}

Fertile fronds or fertile parts of the fronds without much chlorophyll, much contracted, and bearing short-pediceled, naked sporangia. Fronds tall and upright, growing in large crowns from thickened rootstocks, once or twice pinnate. Spores green. Sterile fronds truly bipinnate. .

O. regalis, Royal Fern. Very smooth, pale green. Sterile pinnules 13-25, sessile or short stalked. The fertile pinnules are at the summit of the frond. Common in swamps and wet woods. May and June.

O. Claytoniana, InterRupted Fern. The sterile fronds once pinnate and the lobes entire. Covered when young with loose wool which soon disappears. The fertile fronds are taller than the sterile. Some of the middle pinnae are fertile. The sporangia are greenish, turning brown. Common in May in low ground.

O. Cinnamomea, Cinnamon Fern. Sterile fronds once pinnate and the lobes entire. Rusty woolly when young. Sterile fronds tallest, smooth when full grown. The fertile fronds are separate, appear earlier from the same rootstock, and soon wither; they are twice pinnate, and covered with the cinnamon colored sporangia. Common in swamps.

\section{EQUisetaceaE (Horsetail Family)}

Rush-like plants with jointed and hollow stems arising from running rootstocks. Sheaths occur at the joint-like nodes. The fertile stems bear terminal, cone-shaped structures composed of stalked scales (sporophyllus) which bear sporangia beneath. Equisetum is the only genus. 


\section{EQUISETUM}

Rootstocks perennial, branched. Stems regularly striated. Branches, when present, in whorls from the nodes. (Equus, horse;

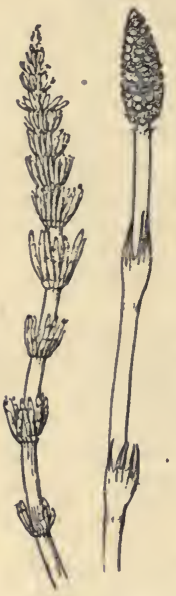

Equisetum arvense, Horsetail. Fertile and sterile shoots. seta, bristle.)

E. arvense, Common Horsetall. Stems annual, the fertile ones brownish, usually unbranched, the sterile ones green, prostrate or erect, branched, appearing after the fertile ones. Common.

\section{TAXACEAE (YEW FAMILY)}

Trees or shrubs with evergreen linear leaves, and dioecious flowers. The staminate flowers are globose. The pistillate ones consist of an erect ovule which becomes a bony, coated seed, more or less surrounded by a large fleshy disk.

\section{TAXUS}

T. canadensis, Yew, Ground Hemlock. Disk of the pistillate flowers cup-shaped, becoming pulpy, red and berry-like. Leaves flat, rigid, scattered, two-ranked, linear, green on both sides. A low, straggling bush.

\section{PINACEAE (Pine FAmily)}

Trees and shrubs. Awl-shaped or needle-shaped leaves. Monoecious or dioecious, flowers borne in scaly catkins, the pistillate ones becoming cones or berry-like. Ovules two or more at the base of the scales. Nearly all evergreen.

\section{PINUS (PINE)}

Leaves 2-5 in each bundle, evergreen. The flowers develop in the spring, the cones maturing the second autumn.

P. Strobus, White Pine. A handsome tall tree of dry or moist woods. Leaves in fives, very slender, light green. Cones elongated, long-stalked, cylindrical, nodding. A timber tree of the greatest importance. 
P. rigida, Pitch Pine. Leaves dark green. Cones ovoid, often in clusters. Scales with a short, stout, and generally recurved prickle. Sandy or barren soil. Very rough dark bark and hard resinous wood.

P. virginiana, Southern Scrub Pine. Leaves short and in twos. Cones sometimes curved and the scales tipped with a straight or curved awl-shaped prickle. Sterile ground. A straggling tree with spreading branches.

\section{P. Banksiana, Northern Scrub Pine.} Leaves in twos, very short and thick, oblique, divergent, cones conical, the scales pointless. A low tree. Barren, sandy, or rocky soil.

P. echinata, Yellow Pine. Leaves in twos and threes, slender and with long sheaths. The scales bear a small and weak prickle. A straight tree with dark green leaves. Dry or sandy soil.

P. resinosa, Red Pine. Leaves in twos, Pinus Banksiana, Northern dark green. Cones ovoid, smooth, their scales slightly thickened and pointless. Dry woods.

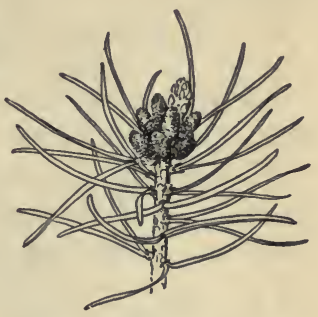
scrub pine. Twig with staminate flowers.

A tall tree with reddish smooth bark and hard wood.

\section{LARIX (LARCH)}

Leaves many in each cluster, deciduous. Small cones borne laterally at the end of short spurs, developed in early spring.
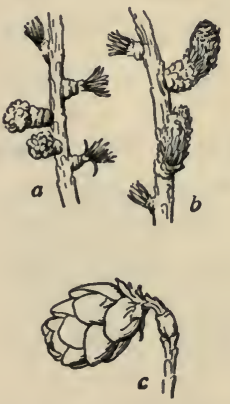

Larix laricina, Tamarack, $a$, staminate twig; $b$, pistillate twig; $c$, cone. Leaves soft, many in a bundle, developed in early spring. Pistillate cones crimson in flower.

L. laricina, TAMARACK. A slender tree with hard and very resinous wood. Occurs chiefly in cold swamps.

\section{TSUGA (HEMLOCK)}

Leaves solitary, flat, whitish along two lines beneath.

T. canadensis, Hemlock. A tall tree with spreading and delicate foliage, bright green above, silvery beneath. Cones on the end of last year's branches, maturing the first year. Leaves petioled. Cones ovoid. Hilly and rocky woods. 


\section{THUJA (ARboR VITAE)}

Leaves scale-like, opposite, and more or less two-ranked. Monoecious.

T. occidentalis, Arbor Vitae, White Cedar. Leaves in four rows on the two-edged branchlets. 'Scales of the cones pointless. Swamps and cool, rocky banks. A tree, Io-2o meters high, with pale, shreddy bark, and light, soft, but very durable wood.

\section{JUNIPERUS (JUNIPER)}

Foliage not two-ranked. Dioecious. Fruit berry-like with bony, ovate seeds. Evergreen.

J. communis, Juniper. Catkins axillary. Leaves in whorls of three. Prickly pointed, channeled and whitish above; thin and narrow, widely spreading. Shrub two meters high or less. Dry soil.
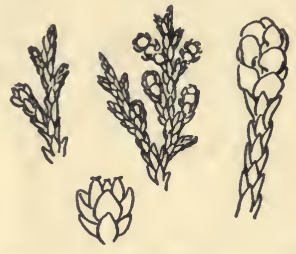

Juniperus virginiana, Red

Cedar. $a$, pistillate twig; $b$, staminate twig; $c$, pistillate flowers; $d$, staminate flowers.
J. virginiana, Red CEDAR. Catkins terminal. Scale-like leaves opposite and entire. Berries on straight peduncles. Ranges in form from a shrub to a tree fifteen to twenty-five meters high, pyramidal in form. Dry hills or deep swamps, especially common in pastures. Bark shreddy. Heart-wood red and aromatic.

\section{SPARGANIACEAE (BUR-REED FAMILY)}

Hydrophytes with alternate, sessile, linear, 2-ranked leaves; flowers monoecious and in globular inflorescences.

\section{SPARGANIUM}

Inflorescences scattered along upper part of stem. Perennials with fibrous roots and creeping horizontal rootstocks. Flowers through the summer. The fertile heads become bur-like.

S. eurycarpum, BUR-REED. Fertile flowers closely sessile. Fruit broadly obovoid. Stems stout and erect. Style short, bearing I or 2 elongated stigmas. Borders of ponds, lakes, and rivers. Common.

\section{ARACEAE (ARUM FAMILY)}

Flowers crowded on a spadix which is usually surrounded by a spathe. A large family, chiefly tropical. 


\section{ARISAEMA}

Spadix globose, enveloped by a fleshy ovoid spathe. Flowers monoecious or dioecious and without perianth, covering only the base of the spadix.

A. triphyllum, INdian TURNIP, JACK-INTHE-PUlPIT. Sterile flowers above the fertile on the club-shaped spadix. Fruit a I-few-seeded scarlet berry. A perennial herb with a corm. Common in rich woods. Most conspicuous in May. The corm is turnip-shaped, and has intensely acrid juice. The spathe is often dark purple or variegated with dark purple and whitish stripes or spots. Leaves usually two, each with three leaflets.

\section{SYMPLOCARPUS}

Spadix globose, enveloped by a fleshy, ovoid spathe. Flowers perfect and perianth present. (Symploka, connection; karpos, fruit. The ovaries are coalescent

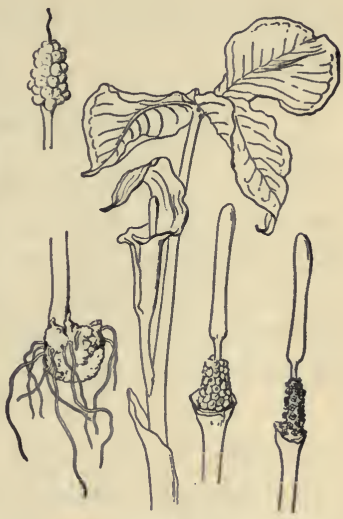

Arisaema triphyllum, Jack-inthe-pulpit. into a compound fruit.)

S. foetidus, Skunk Cabbage. Stamens 4, opposite the sepals. Fruit

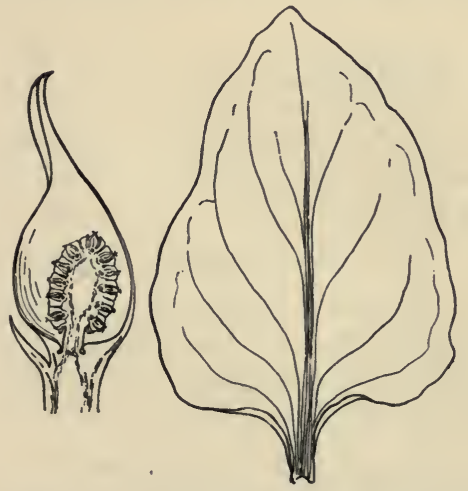

Symplocarpus foetidus, Skunk Cabbage. Leaf and section of inflorescence. SPRING FLORA-3 a globular mass, composed of the enlarged and spongy spadix, enclosing the spherical seeds just beneath the surface. A perennial herb with a strong odor like that of the skunk. A cluster of large, broad leaves preceded in earliest spring by the nearly sessile spathes which barely emerge from the ground. The spathe is spotted and striped with purple and yellowish green. Swampy places.

\section{ACORUS}

Spadix cylindrical. Spathe not obvious. Flowers perfect. 
Perianth present. The spadix is borne on the side of a leaflike scape.

A. Calamus, Sweet Flag, Calamus. Sepals and stamens 6. Aromatic, especially the thick creeping rootstocks from which the drug calamus is obtained. Leaves sword-like. Scape leaf-like and extending far beyond the yellowish-green spadix. Margins of streams and swamps.

\section{COMMELINACEAE (SPIDERWort FAMily)}

Herbs with fibrous and sometimes thickened roots, jointed and often branching leafy stems, and mostly perfect flowers, which are often irregular. Calyx and corolla distinct, composed of three persistent and usually green sepals and three usually ephemeral petals. Style I, stigma undivided. The leaves are entire and parallel veined.

\section{TRADESCANTIA}

Flowers regular, showy. Filaments bearded. Perennials. Stem juice copious, mucilaginous. Leaves keeled. The ephemeral blue

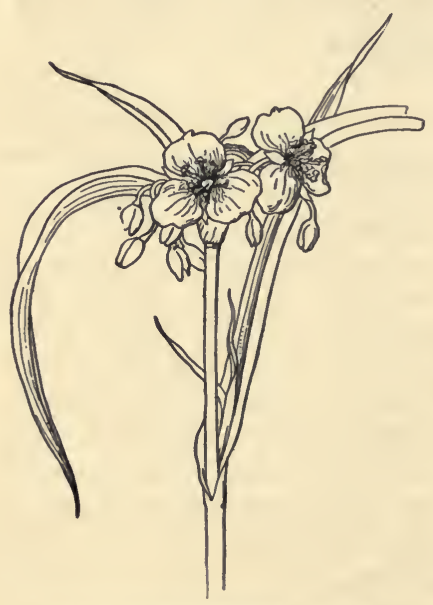

Tradescantia virginiana, Spiderwort. to purple flowers, occurring in umbelled clusters, are produced throughout the summer. (Named for Tradescant, gardener to Charles the First of England.)

\section{ITIACEAE (Lily Family)}

Herbs, with regular and symmetrical almost always 6-androus flowers.

\section{VERATRUM}

Flowers polygamo-monoecious. Stem pubescent above, arising from a running rootstock. (Vere, truly; ater, black.)

V. viride, False Hellebore. A somewhat pubescent perennial with simple stems arising from a thickened base which produces coarse fibrous roots which are very poisonous. The leaves are 3-ranked and strongly veined. The dull flowers 
occur in panicles; in summer. Stem stout, very leafy to the top. Leaves broadly oval and sheath-clasping. The panicle pyramidal, the perianth yellowish-green. Swamps and low grounds.

\section{UVULARIA}

Flowers perfect and terminal. Style 3 -cleft to below the middle. Stems leafy and round. Leaves perfoliate. (Name from the flowers hanging like the uvula or palate.)

U. perfoliata, Bellwort. Perianth narrowly bell-shaped, lily-like. Rootstock short and roots fleshy. The yellowish drooping flowers occur in spring, and are solitary on terminal peduncles. Glaucous throughout. Leaves glabrous. Stamens shorter than the styles. Frequent in rich woods.

U. grandiflora, Bellwort. Similar to foregoing but not glaucous. Leaves whitish-pubescent beneath. The stamens are longer than the styles.

\section{OAKESIA}

Stem angled. Leaves sessile and the flowers opposite them. (Named for William Oakes, New England botanist, I799 to I848.)

O. sessilifolia. The flowers resemble those of the bellwort. The acutely angled stem arises from a slender creeping rootstock and bears sessile clasping leaves, and I or 2 flowers, terminal on slender peduncles. The leaves are acute at each end, glaucous beneath. Woods and thickets.

\section{ALLIUM (Onion, Garlic)}

Flowers perfect, umbellate. Style single, long. Plants with a strong odor. Perianth of 6 sepals, often becoming dry and persistent. The leaves and usually the scape-like stem arise from a coated bulb. Flowers in a simple umbel, some or all of them frequently replaced by bulblets. (Allium is the ancient latin name of garlic.)

A. Canadense, Wild GarLIC. Bulb small, bulb-coat somewhat fibrous. The umbel densely bulbiferous, the flowers being few or often none. Moist meadows. May and June.

\section{ERYTHRONIUM}

Flowers perfect. Perianth-segments distinct and petaloid. Style single, long, and uncleft. Nearly stemless herbs with two 
smooth and shining flat leaves tapering into petioles and sheathing the base of the usually I-flowered scape which rises from a deeply placed bulb. Flowers rather large, nodding, vernal.

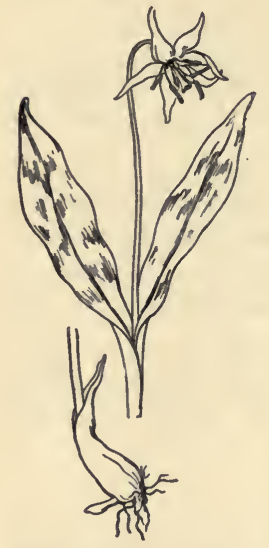

Erythronium americanum, Yellow adder's tongue.

E. americanum, YELLOW AdDER'S-TONGUE. Leaves mottled, perianth light. yellow, stigmas united. Rich ground.

E. albidum, White Adder's-tongue, Dog'sTоотн Violet. Leaves less spotted than those of the yellow-flowered species. Perianth pinkish white, the stigmas short and spreading. Rich ground.

\section{CAMASSIA}

Flowers perfect, light blue, and in long racemes. Perianth-segments distinct. Style single, slender, and uncleft. Stem a scape from a bulb. The perianth slightly irregular. Leaves linear. (From the Indian name quamash or camass.)

C. esculenta, Wild Hyacinth. Low herb. Leaves keeled. Bracts of the racemes longer than the pedicels. Rich ground.

\section{SMILACINA}

Flowers perfect. Fruit a globular berry. Perianth-segments distinct. Leafy-stemmed. Flowers 6-parted, racemose or paniculate. The berries at first greenish or yellowish, speckled with brown, and changing to dull red. Perennial herbs, with simple stems arising from rootstocks. Flowers white and sometimes fragrant. (Name a diminutive of Smilax.)

S. racemosa, False Solomon's Seal. Flowers on very short pedicels in a terminal racemose panicle. Stamens longer
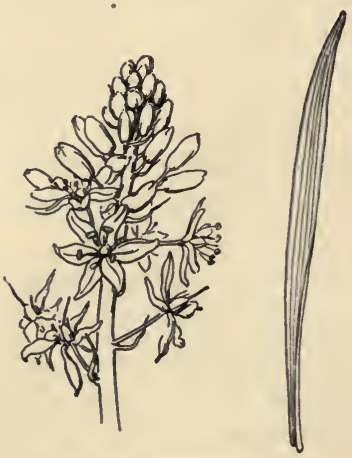

Camassia esculenta, Wild hyacinth. than the very small sepals. Rootstock fleshy. Leaves numerous, oblong, taper-pointed. Frequent in moist woods. 
S. stellata. Flowers larger than the foregoing and on solitary pedicels in a simple, few-flowered raceme. Stamens not longer than

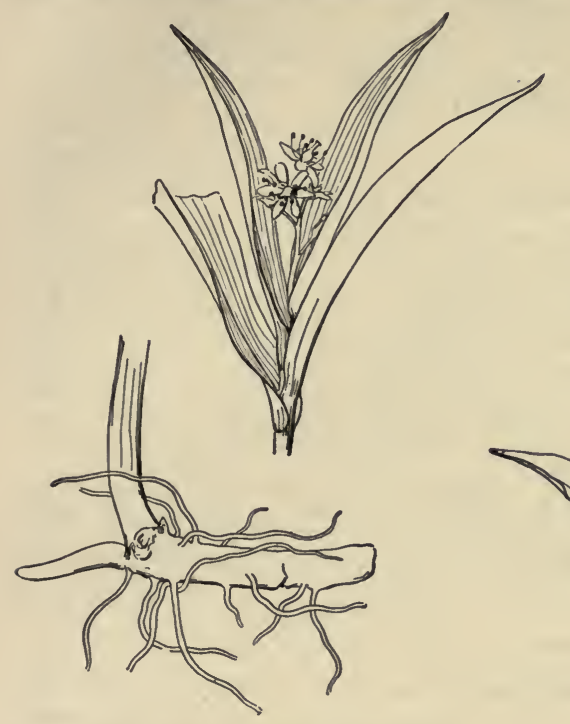
the sepals. Rootstock rather slender. Moist banks, common.

\section{MAIANTHEMUM}

Flowers perfect. Fruit a berry. Perianth segments distinct. Low. Stem

Smilacina stellata, False Solomon's seal. Inflorescence and rootstock.

Smilacina racemosa, False Solomon's seal.

I-3 leaved. Flowers 4-parted, solitary or fascicled, in a simple raceme. (Name from Maius, May, and anthemos, a flower.)

M. canadense, WILd LiLy-of-The-VAlley. Leaves lanceolate or ovate, cordate at base, sessile or very shortly petioled. Moist woods.

\section{DISPORUM}

Flowers perfect. Fruit a berry. Perianth-segments distinct. Leafy-stemmed. Flowers few in terminal umbels, or solitary. Perianth narrowly bell-shaped, the 6 lanceolate or linear divisions deciduous. Downy low herbs, with creeping rootstocks. Stems erect and sparingly branched above. Leaves thin, ovate, and closely sessile. Flowers greenish-yellow and drooping. (Name from dis, double, and spora, seed, in allusion to the two ovules in each cell of the ovary.) 
D. lanuginosum. Leaves taper-pointed. Flowers solitary or in pairs. Perianth soon spreading, twice the length of the stamens, greenish. Stigmas 3. Rich woods.

\section{POLYGONATUM}

Flowers perfect. Fruit a berry. Perianth-segments connate. Stem leafy. Peduncles axillary, I-8 flowered. Perianth cylindrical, 6-lobed, the 6 stamens inserted about the middle of the tube, and included in it. Berry globular, black or blue. Perennial herbs, with simple stems from creeping knotted rootstocks, naked below, bearing above the nearly sessile or half-clasping leaves, and the axillary nodding greenish flowers. (Name from polu, many, and gonu, knee, alluding to the numerous joints of the rootstock.)

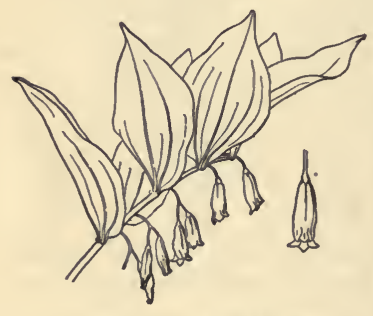

Polygonatum biflorum, Solomon's seal.

P. biflorum, Small Solomon's Seal. Glabrous, except the nearly sessile leaves, which are usually minutely pubescent as well as pale or glaucous beneath. Stem slender, $3-9 \mathrm{dm}$. high, peduncles $\mathrm{I}-3$ but mostly 2 -flowered, filaments slightly roughened, inserted toward the summit of the perianth. Wooded hillsides.

P. commutatum, Large Solomon's Seal. Glabrous throughout. Stem stout, $0.6-2 \mathrm{~m}$. high. Leaves partly clasping or the upper nearly sessile. Peduncles several flowered. Filaments smooth and naked, or nearly so, and inserted in the middle of the tube. Meadows and river banks. June.

\section{MEDEOLA}

Flowers perfect. Perianth-segments distinct. Style branches distinct. Fruit a berry. The cauline leaves in 2 whorls. Flowers in umbels. Styles filiform. (Named for the sorceress Medea, for its supposed medicinal virtues.)

M. virginiana, Cucumber-Root. Perianth recurved, the 3 sepals and 3 petals oblong and alike, pale greenish-yellow, deciduous. Stamens 6 , the anthers being shorter than the slender filaments. Styles stigmatic on the upper side, recurved from the globose ovary, long and thread-like, deciduous. Fruit a globose, dark purple berry with few 
seeds. A perennial herb with a simple, slender stem which is woolly, and rises from a horizontal white tuber which has the taste of cucumber. The stem bears near the middle a whorl of 5-9 leaves, and another whorl, usually of 3 , much smaller leaves at the top, the latter subtending a sessile umbel of small recurved flowers. Rich damp woods.

\section{TRILLIUM (WAKE ROBIN)}

Flowers perfect. Perianth-segments distinct. Style branches distinct. Fruit a berry. The cauline leaves 3 in a single whorl. Style short, thick, the stigmatic surface irregular. Sepals 3, lanceolate, spreading, herbaceous, persistent. Petals 3, larger, withering in age. Stamens 6; anthers linear, on short filaments, adnate. Styles awl-shaped or slender, stigmatic down the inner side. Low perennial herbs, with a stout and simple stem rising from a tuber-like rootstock. At the top a whorl of 3 broadly ovate leaves and a large terminal flower; vernal. (Named from tres, three; all the parts being in threes.) Monstrosities are not infrequent.

T. sessile, Ovary and fruit 6-angled. Flower sessile. Leaves sessile, usually mottled. Sepals spreading. The sessile petals are erect and spreading, narrowly lanceolate, dull purple, varying to greenish. Moist woods.

T. recurvatum. Ovary and fruit 6-angled. Flower sessile. Leaves contracted at the base into a petiole, usually mottled. Sepals reflexed. The bases of the petals narrowed into a claw. Rich woods.

T. erectum. Ovary and fruit 6-angled. Flower pediceled. Anthers when mature extending beyond the stigmas. Petals ovate to lanceolate. Brown-

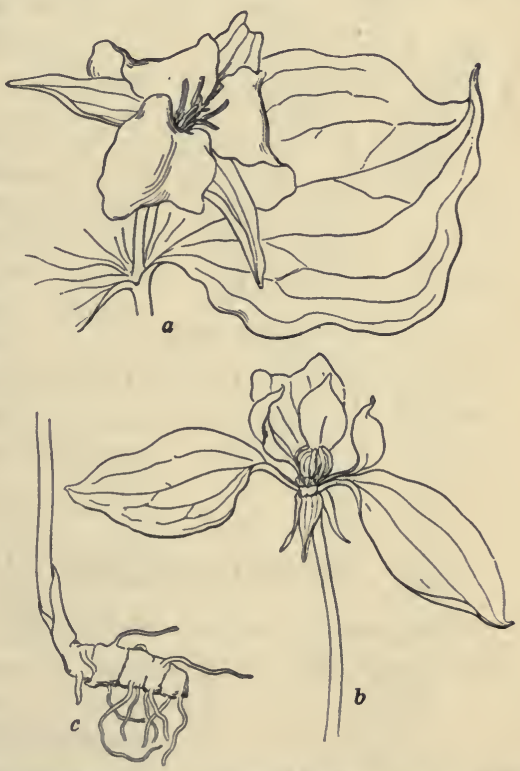

Trillum. $a, T$. grandiflorum. $b, T$. recurvatum, flower and $(c)$ rootstock. 
purple or white or greenish. Stigmas stout, distinct, spreading or recurved. Rich woods. Flowers with a disagreeable odor.

T. grandiflorum. Ovary and fruit 6-angled. Flower pediceled. Anthers when mature extending beyond the stigmas. Petals oblanceolate, white, turning rose color or marked with green. Stigmas very slender, rather erect, and somewhat coherent. Rich woods.

T. cernuum. Ovary and fruit 6-angled. Flower pediceled. Anthers when mature not extending beyond the stigmas. Leaves very broadly ovate. Peduncles usually recurved. Petals white or pink, wavy, recurved, spreading. Moist woods.

T. undulatum. Ovary and fruit 3-lobed or angled. Filaments slender, about equaling the anthers. Leaves with petioles, ovate, taperpointed. Petals pointed, wavy, widely spreading; white, painted with purple stripes at the base; shorter than the peduncle. Called the Painted Trillium. Cold woods and swamps.

\section{SMILAX}

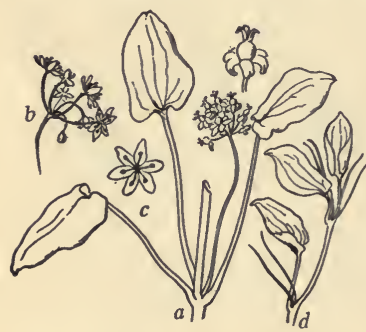

Smilax herbacea, Carrion flower. $a$, pistillate inflorescence; $b$, staminate inflorescence; $c$, staminate flower; $d$, vegetation shoot with tendrils.

Flowers dioecious, umbellate. Leaves net-veined: Perianth-segments distinct, deciduous, small, greenish or yellowish. Fruit a small berry.

S. herbacea, CarRIon-Flower. Stem herbaceous, climbing, not prickly. Flowers carrion-scented. Berries bluish-black with a bloom. Leaves ovate or rounded, mostly heart-shaped at base, abruptly acute. Peduncles $4-20 \mathrm{~cm}$. long, often much longer than the leaves, 20-40 flowered. Common in moist meadows and on river banks. June.

\section{AMARYLLIDACEAE (AMARYllis Family)}

Herbs, chiefly bulbous and with scapes, linear, flat root-leaves, and regular, perfect, 6-androus flowers.

\section{HYPOXIS}

Stemless small herbs with grass-like and hairy linear leaves and 
slender few-flowered scapes. Perianth spreading, 6-parted nearly down to the ovary, persistent.

H. hirsuta, Yellow-eyed Grass. The leaves are longer than the I-4 flowered scape. Flowers in an umbel. The divisions of the perianth yellow within and hairy and greenish without. Meadows and open woods.

\section{IRIDACEAE (IRIS FAMILY)}

Herbs, with vertical 2-ranked leaves, and conspicuous perfect flowers, arising from a spathe of 2 or more leaves or bracts.

\section{IRIS}

Branches of the style or the stigmas opposite the anthers. Sepals spreading or recurved. Petals spreading or erect. Stigmas petal-like. (Iris, the rainbow.)

I. versicolor, BLUE FLAG. Stems leafy and rather tall, arising from thickened rootstocks. Flowers violet-blue, variegated with green, yellow, or white, and purple-veined. Stems stout angled on one side, I.5-9 dm. high. Leaves sword-shaped, glaucous. Petals flat, half as long as the sepals. Style-branches with slightly overlapping petaloid lobes. Wet places. May to July.

\section{SISYRINCHIUM}

Branches of the style alternate with the anthers. Flowers regular. Root fibrous. Filaments united. Stigmas thread-like. Sepals and petals alike, spreading. Low slender perennials with grass-like leaves, 2-edged stems and umbel-clustered small flowers coming from a usually 2-leaved spathe.

S. angustifolium, BLUE-EYED GRASS. Spathe solitary. The plant stiff, erect or ascending, and glaucous, $\mathrm{I}-5 \mathrm{dm}$. high. The simple stems distinctly winged. Spathes

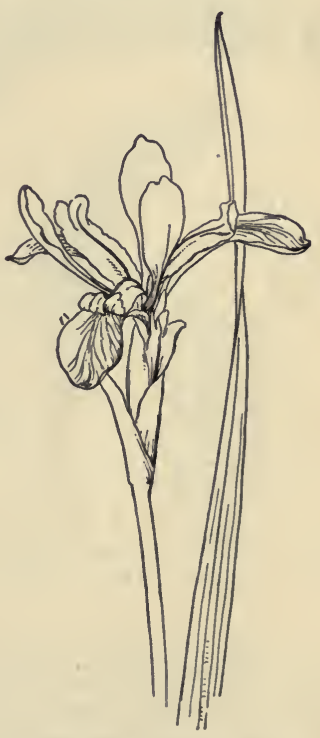

Iris versicolor, Blue flag. 
green, the outer bract with margins united above the base. Capsules dull brown or purple-tinged. Meadows, fields, and damp, sandy soil.

\section{SALICACEAE (Willow Family)}

Dioecious trees or shrubs with both kinds of flowers in catkins, one flower to each bract. No perianths. Stigmas 2, often 2-lobed. Leaves alternate and undivided, with stipules which are either scale-like and deciduous or leaf-like and persistent.

\section{SALIX (WILLOW)}

Leaves mostly long and pointed. Buds covered by a single scale. Catkins appearing before or with the leaves. Largely

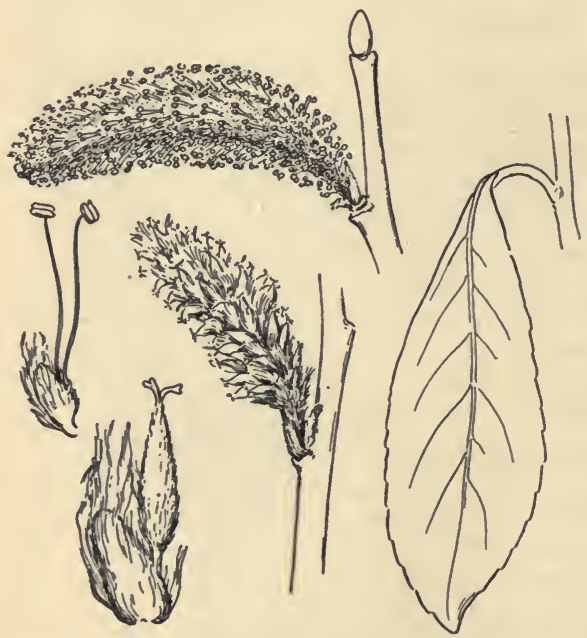

Salix, Willow. Leaf, and staminate and pistillate flowers and inflorescences. win $d$-pollinated and freely hybridizing.

S. nigra, Black WILLow. Scales yellowish, falling before the capsules mature. Filaments hairy below. Stamens 3-5 or more. Shrub, or, when well developed, a roughbarked tree 5-30 m. high. Young branches easily breaking off. Leaves narrowly lanceolate, very long-a $t \mathrm{t}$ e $\mathrm{nu}$ a t $\mathrm{e}$, often downy when young, but becoming green and glabrous except the short petiole and midrib, closely serrulate. Scales softpubescent outside. Banks of streams, ponds, and lakes.

S. amygdaloides, PeAch-Leaved Willow. Scales yellowish, falling before the capsules mature. Filaments hairy below. Stamens 3-5 or more. Leaves lanceolate or ovate-lanceolate, pale or glaucous beneath. Petioles slender. Stipules minute and very early deciduous. 
The pistillate catkins become very loose in fruit. Common in swamps westward.

S. longifolia, SAND-BAR Willow. Scales yellowish, falling before the capsules mature. Filaments hairy below. Stamens 2. Leaves tapering at each end, nearly sessile, more or less silky when young, smooth and green on both sides when mature. Stipules small and deciduous. A shrub or small tree which spreads extensively on alluvial deposits and forms dense clumps.

S. cordata, Pussy Willow. Scales persistent, colored at the tip. Stamens 2. Filaments glabrous. Capsules glabrous. Stipules persistent, usually conspicuous. A widely distributed shrub characteristic of wet places. A free hybridizer.

S. Discolor, Pussy Willow. Scales persistent, colored at the tip. Stamens 2. Filaments glabrous. Capsules pubescent. Catkins sessile on the old wood, naked at base, appearing before the leaves, thick, cylindrical, appearing in earliest spring. Scales dark red, brown, or blackish, densely clothed with long glossy hairs. Large shrub or small

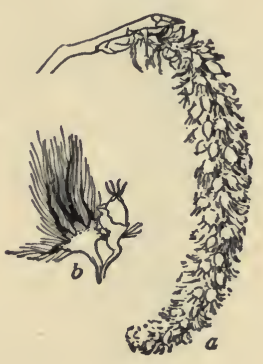
tree common in low meadows or along river banks.

\section{POPULUS}

Trees with broad and more or less heartshaped or ovate, toothed leaves, and often angular branches. Buds scaly, covered with resinous varnish. Catkins long and drooping, appearing before the leaves. Flow-

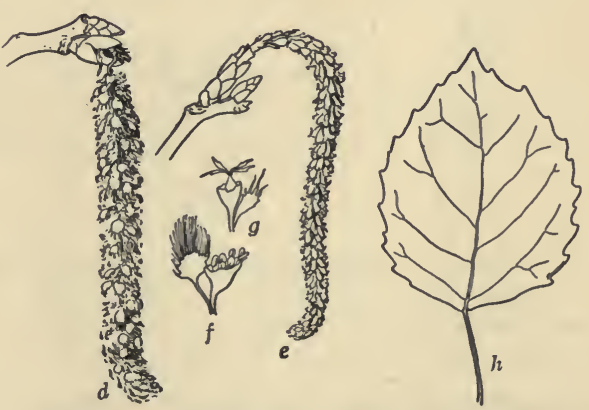

a-c, Populus tremuloides, Aspen; $a$, pistillate catkin; $b$, pistillate flower with scale; $c$, leaf; $d-h$, $P$. grandidentata, Large-toothed aspen; $d$, staminate catkin; $e$, pistillate catkin; $f$, staminate flower; $g$, pistillate flower with scale; $h$, leaf. 
ers arise from a cup-shaped disk. The stamens are \&-30 or more.

P. tremuloides, Trembling Aspen. A tree 6-20 m. high, with smooth greenish-white bark. Leaves roundish-heart-shaped, with a short sharp point and small somewhat regular teeth. Petioles long and slender and laterally, flattened. Scales cut into 3-4 deep linear divisions, fringed wh long hairs. Bud scales glabrous, or merely ciliate. Common in thickets and clearings.

P. grandidentata, LaRge-toothed Aspen. Tree often $20 \mathrm{~m}$. high with smoothish gray bark. Leaves roundish-ovate, with large and ir-
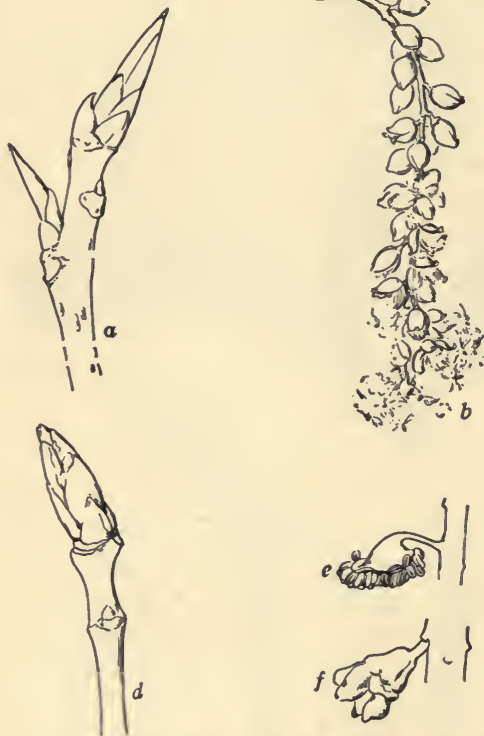
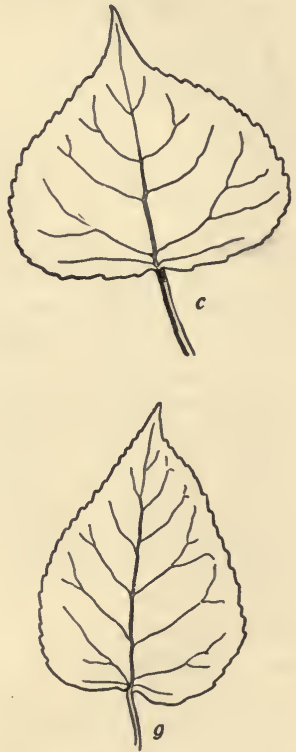

$a-c, P o p u l u s$ deltoides, Cottonwood; $a$, winter bud; $b$, fruit; $c$, leaf. $d-g, \boldsymbol{P}$. balsamifera, Balsam poplar; $d$, winter bud; $e$, staminate flower; $f$, pistillate flower; $g$, leaf.

regular sinuate teeth, densely covered when young with white silky wool, smooth on both sides when mature. Petioles laterally flattened. Scales cut into 5-6 unequal small divisions, slightly fringed. Budscales tomentose.

P. balsamifera, Balsam Poplar. Tree 6-30 m. high, the buds large 
and varnished with an abundant and fragrant resin. Petioles little if at all laterally flattened. Stamens 20-30.

P deltoides, CotTonwoop. Tree $15-30 \mathrm{~m}$. high. Leaves broadly deltoid. Petioles long and laterally flattened. Scales fringed but not hairy. Stamens 60 or more. Capsules on slender pedicels, in long catkins. Borders of streams.

\section{MYRICACEAE (Sweet Gale Family)}

Monoecious or dioecious shrubs, with each kind of flowers in short scaly catkins, and resinous-dotted often fragrant leaves.

\section{MYRICA}

The only genus. Flowers solitary under a scale-like bract and with a pair of bractlets, the sterile in ellipsoid or cylindrical, the fertile in ovoid or globular catkins, from axillary scaly buds; stamens 2-8; filaments somewhat united below; anthers 2-celled. Fruit small globular or short-cylindric, dry, coated with resinous grains or wax.

M. carolinensis, BAyberRy. Shrub I-2 $\mathrm{d}$. high; leaves oblong, entire or somewhat crenately toothed, thinner and more flaccid than in the preceding, mostly obtuse, $1.5-4 \mathrm{~cm}$. broad, green and resinousdotted on both sides; fruit $3.5-4 \mathrm{~mm}$. in diameter. Sandy or sterile soil, chiefly near the coast.

M. asplenifolia, SweEt Fern: Shrub 3-6 dm. high, with sweetscented, fern-like, linear-lanceolate leaves; stipules half heart-shaped; scales of the sterile catkins kidney- or heart-shaped, pointed. Sterile soil.

\section{JUGLANDACEAE (WALNUT FAMily)}

Trees, with alternate pinnate leaves, and no stipules; flowers monoecious; the sterile, in catkins with an irregular calyx adnate to the bract; the fertile, solitary or in a small cluster or spike; with a regular 3-5 lobed calyx adherent to the incompletely 2-4 celled but only I-ovuled ovary. Fruit a kind of dry drupe, with a crustaceous or bony nutshell, containing a large 4-lobed seed. Cotyledons fleshy and oily, 2-lobed. Petals sometimes present in the 
fertile flowers. A small family of important trees, consisting chiefly of the two following genera.

\section{JUGLANS}

Stamens 12-40; filaments free, very short. Fertile flowers solitary or several together on a peduncle at the end of the branch, with a 4-toothed calyx, bearing 4 small petals at the sinuses. Styles 2, very short; stigmas 2, somewhat club-shaped and fringed. Fruit with a fibrous-fleshy indehiscent epicarp, and a mostly rough irregularly furrowed endocarp or nutshell. Trees, with odd-pinnate leaves of many serrate leaflets. Pith in plates.

J. cinerea, Butternut. Leaflets 7-17, oblong-lanceolate, pointed, rounded at base, downy especially beneath, the petioles and branchlets downy with clammy hairs; fruit ellipsoid, clammy, pointed, the nut deeply sculptured and rough with ragged ridges, 2-celled at the base. Rich woods. Trunk $16-30 \mathrm{~m}$. high with gray bark, widely spreading branches, and lighter brown wood than in the next.

J. nigra, Black Walnut. Leaflets II-I7, ovate-lanceolate, taperpointed, somewhat heart-shaped or unequal at base, smooth above, the lower surface and the petioles minutely downy; fruit spherical, roughly dotted, the nut corrugated, 4-celled at top and bottom. Rich woods. A large and handsome tree with rough dark bark and valu-. able purplish-brown wood.

\section{CARYA}

Fine timber trees with hard and very tough wood. From the scaly buds, in spring, usually both kinds of flowers arise, the sterile below and the fertile above the leaves. The fruit has a four-valved exocarp (the hull), a smooth and bony endocarp (the shell of the nut), and a single, four-lobed seed (the kernel). The nuts ripen and fall in October. (Karua, an ancient name of walnut.)

C. ovata, Shag-bark Hickory. The bark of the trunk exfoliates in rough strips or plates. The inner bud-scales become large and conspicuous and persist till the flowers are fully developed. Leaflets 5-7. The husk of the fruit splits into thick and woody valves. The seed is sweet. A large and handsome tree. 
C. glabra, Pignut Hickory. The bark does not exfoliate. The seed is bitterish. Nut thick walled. Leaflets 5-7: Winter buds brownish, rounded.

C. cordiformis, Bitternut Hickory. Like C. glabra, but leaflets 7-II, and nut thin-walled. Winter buds yellow, pointed.

\section{BETULACEAE (Birch FAMily)}

Monoecious trees or shrubs. Leaves simple, alternate, and straight veined, and with deciduous stipules. The staminate flowers in catkins, the pistillate ones in clusters, spikes, or in scaly catkins.

\section{CORYLUS}

Shrubs or small trees, with doubly-toothed leaves. Flowers in early spring. The staminate catkins arise from the scaly buds of the axils of the preceding year, while the pistillate ones terminate the early leafy shoots. The nut is enclosed in a leafy cup formed by the two bractlets enlarged and often grown together and lacerated at the border; cotyledons very thick; sweet and edible.

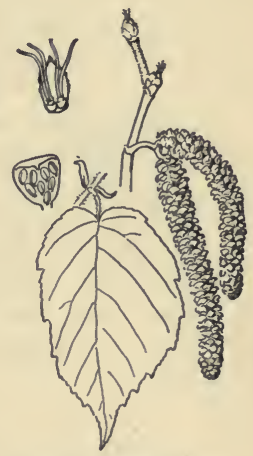

Corylus americana, Hazelnut.

C. americana, HAZELNUT. Leaves roundish-heart-shaped. Involucre open above. Thickets.

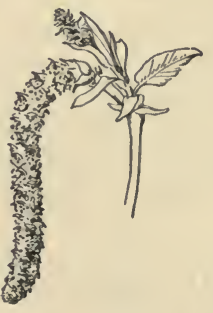

Ostrya virginiana, Hop hornbeam. Pistillate and staminate catkins.

\section{OSTRYA}

Slender trees with very hard wood, brownish furrowed bark, and leaves resembling those of birch. The flowers appear with the leaves. The fruit is enclosed in a bladdery bag (the inflated involucre), which is much larger than the small smooth nut within. This inflated involucre gives an appearance like that of the fruit of hops.

O. virginiana, HoP HoRnbeam. Leaves oblong- 
ovate, taper-pointed, very sharply double-serrate, downy beneath, II-I 5 principal veins. Rich woods.

\section{CARPINUS}

Trees or tall shrubs with gray bark which has the appearance of being very tight-fitting to the wood, giving the stems and branches a "hard-muscled" appearance. The slender buds and straight-veined leaves resemble those of beech.

C. caroliniana, BLUE BEECH. Leaves ovate-oblong, pointed, sharply double-serrate. Along streams.

\section{BETULA}

Trees or shrubs with the outer bark often separable in sheets and that of the smaller branches dotted. Buds sessile and scaly. Staminate catkins terminal and lateral, sessile, formed in summer, remaining naked through winter, and expanding in early spring. They appear with or precede the leaves. The pistillate catkins are ovoid to cylindrical and usually terminate the very short 2-leaved early lateral branches.

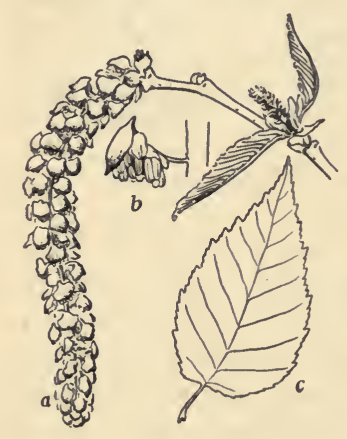

Betula lutea, Yellow birch; $a$, branch with staminate and pistillate catkins; $b$, single staminate flowers; $c$, leaf.

B. lenta, SweEt Birch. Bark and twigs sweet-aromatic. Leaves green on both sides. Bark of trunk dark brown and tight, in age becoming ashy-brown and furrowed. The fruiting catkins short-cylindric. Rich woods.

B. lutea, Yellow Birch. Bark and twigs sweet-aromatic, but less so than in preceding species. Leaves green on both sides. Bark of trunk yellowish- or silverygray, detaching in very thin filmy layers. The fruiting catkins narrow-ovoid to subglobose. Rich moist woods.

B. nigra, River BIRCH. Bark not aromatic. Leaves whitish beneath. Bark greenish-brown. Twigs reddish. Leaves acutish at both ends, downy beneath when young. Petioles and peduncles and the thick-cylindric catkins woolly-pubescent. Banks of streams and swamps. 
B. populifolia, White Birch. Bark dull, chalky- or ashy-white, smooth and tight, the layers not readily exfoliating. Staminate catkins usually solitary. Leaves triangular, very taper-pointed, smooth and shining on both sides, tremulous on very slender petioles. Sandy or rocky soil. Commonest near the coast.

B. alba papyrifera, CANOE BIRCH. Bark lustrous, creamy or pinkish-white to bronze, freely splitting into paper-like layers. Staminate catkins mostly 2 or 3 . Young leaves pubescent beneath. Large shrub or medium-sized tree.

\section{ALNUS}

Shrubs or small trees with few-scaled leaf-buds and solitary or often racemose-clustered catkins. Flowers, in the following species, developed in earliest spring before the leaves, the catkins all coming from naked buds formed the preceding season; fruit wingless, or with a narrow dry margin.

A. incana, Speckled Alder. Shrub or small tree, leaves broadly elliptical to ovate, mostly rounded at base, sharply and doubly serrate, the upper surface dark green, the lower mostly downy, at least on the veins. Stipules lanceolate. Swamps and borders of streams.

A. rugosa, Sмоотн Alder. Shrub or small tree, leaves obovate, acute at base, sharply and

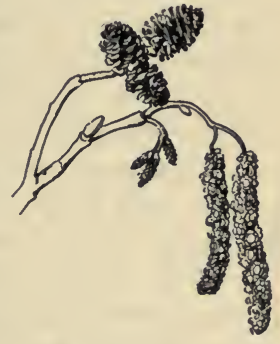

Alnus incana, Speckled alder. almost regularly serrate with minute teeth, thickish, green on both sides. Stipules oval. Sometimes intergrades with $A$. incana.

\section{FAGACEAE (ВеEсh Family)}

Monoecious trees or shrubs, with alternate, simple, straightveined leaves and deciduous stipules. The one-seeded nut enclosed in a cupule consisting of more or less consolidated bracts which become hard.

\section{FAGUS}

Trees with a close and smooth ash-gray bark, and undivided strongly straight-veined leaves. The flowers appear at the same time as the leaves, the yellowish staminate ones arising from the SPRING FLORA-4 
lower, and the pistillate ones from the upper axils of the leaves. (Name from phagein, to eat, in allusion to the edible nuts.)

F. grandifolia, BEECH. Large tree, leaves oblong-ovate, taperpointed, distinctly and often coarsely toothed, light green. The prickles of the grayish or yellowish fruit filiform, elongated, recurved or spreading. Rich uplands.

\section{QUERCUS (OAK)}

Flowers greenish, yellowish, or reddish. All the species incline to hybridize freely. The involucre forms a scaly cup around the base of the rounded nut or acorn.

Q. alba, White OAK. Leaves when young whitish beneath, when mature pale or glaucous beneath, bright green above, obovate-oblong, obliquely cut into 5-9 oblong or linear and obtuse, mostly entire lobes. The cup hemispherical saucer-shaped, roughish at maturity, much shorter than the ovoid $(2-3 \mathrm{~cm}$. long) acorn. Dry upland woods.

Q. stellata, Post OAK. Leáves grayish or brownish, downy underneath, dark green and rough above, thickish, 5-7 rounded divergent lobes, the upper ones much larger and often I-3 notched. Acorn I-2 $\mathrm{cm}$. long. Sandy or sterile soil.

Q. macrocarpa, BUR OAK. Leaves obovate or oblong, sometimes nearly entire, irregular, downy or pale beneath, the lobes sparingly and obtusely toothed, or in the smaller ones entire. The cup deep, thick and woody (2-5 cm. across) with hard, thick, pointed, and conspicuously imbricated scales, the upper ones usually making a mossyfringed border. The acorn is broadly ovoid and half covered by or entirely enclosed by the cup. A large and valuable tree, extremely variable in the size and fringe of the acorn cups. Rich soil.

Q. bicolor, Swamp White OAK. Leaves obovate or oblong ovate, wedge-shaped base, usually soft downy beneath. The cup $\frac{1}{3}$ to $\frac{1}{2}$ as long as the acorn, woody, the upper scales awn-pointed, sometimes forming a mossy-fringed margin. Acorn $2-3 \mathrm{~cm}$. long, peduncled. A large tree with flaky bark. Borders of streams and swamps.

Q. muhlenbergii, Chestnut OAK. Leaves slender petioled, often oblong or even lanceolate, usually acute or pointed, mostly obtuse or rounded at base, almost equally and rather sharply toothed. The cup nearly sessile, shallow, thin, and composed of small scales. The acorn globose or obovoid, I.5 to $2 \mathrm{~cm}$. long. Dry limestone hillsides and rich bottoms. A tall tree whose bark becomes flaky. 
Q. Prinus, Chestnut OAK. Leaves thick, obovate, or oblong to lanceolate, sometimes acuminate, with an obtuse or acute base, undulately crenate-toothed, pale and minutely downy beneath. Cup thick and composed of hard and stout scales. A large tree with thick and deeply furrowed bark. Rocky banks and hillsides.

Q. rubra, RED OAK. Cup saucer-shaped or flattish with a narrow raised border, $1.8-2.5 \mathrm{~cm}$. broad, of closely appressed scales, sessile or on a very abrupt stalk, very much shorter than the narrow-ovoid acorn, which is $2-3 \mathrm{~cm}$. long. Leaves rather thin, turning dark red after frost, moderately pinnatifid, the lobes acuminate from a broad base, with a few coarse teeth. The bark of the trunk dark-gray and smoothish. Timber coarse and poor. Common both in rich and poor soil.
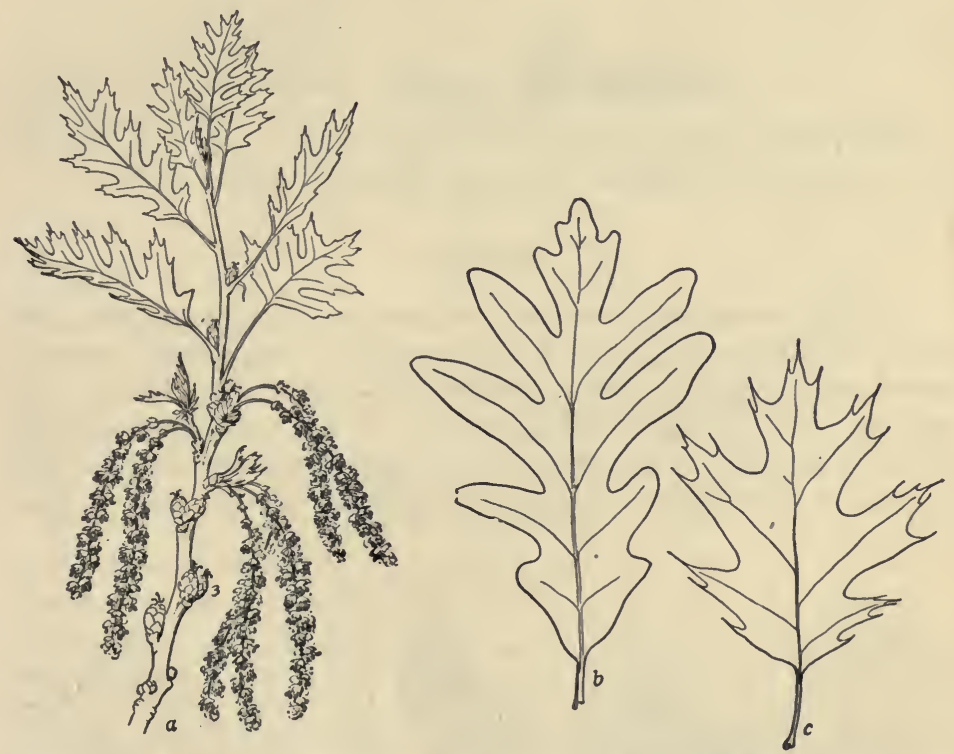

Quercus, Oak; $a, Q$. velutina, Black oak, branch with young leaves and pistillate and staminate catkins; $b$, leaf of $Q$. rubra, Red Oak; $c$, leaf of $Q$. alba, White oak.

Q. palustris, PIN OAK. Cup flat saucer-shaped, sometimes con.tracted with a short scaly base or stalk, fine scaled, very much shorter than the usually globose acorn which is $I-I .5 \mathrm{~cm}$. long. Leaves deeply 
pinnatifid, with divergent lobes and broad rounded sinuses. Low grounds, chiefly on the coastal plain and in the Mississippi basin.

Q. coccinea, Scarlet OAK. Cup top-shaped or hemispherical with a conical base, $1.5-2.2 \mathrm{~cm}$. broad, coarsely scaly, covering half or more of the short ovoid acorn, the scales brown. Leaves, at least on fullgrown trees, bright green, shining above, glabrous beneath, turning red in autumn, deeply pinnatifid, the slender lobes divergent and sparingly cut-toothed. The bark of the trunk is gray and the interior reddish. Dry soil.

Q. velutina, BLACK OAK. Cup hemispherical with a conical base, I.8-2.3 cm. broad. The acorns are ovoid to hemispherical, $1.2-2 \mathrm{~cm}$. long, light brown, often pubescent. Leaves variously divided, ordinarily with hairy tufts in the axils beneath. Bark dark brown and rough, internally orange. This bark is largely used in tanning. Dry uplands.

\section{URTICACEAE (Nettle Family)}

Plants with stipules, and monoecious or dioecious or rarely (in the elm) perfect flowers. A large family mostly tropical.

\section{ULMUS}

Trees with alternate, serrate, pinnately-veined leaves and stipules which soon drop off. Flowers mostly polygamous, upon the last year's branches. Fruit winged all around, one-seeded. The flowers are purplish or yellowish, in lateral clusters, appearing in early spring. The leaves are strongly straight-veined, short petioled, and oblique or unequally somewhat heart-shaped at base.
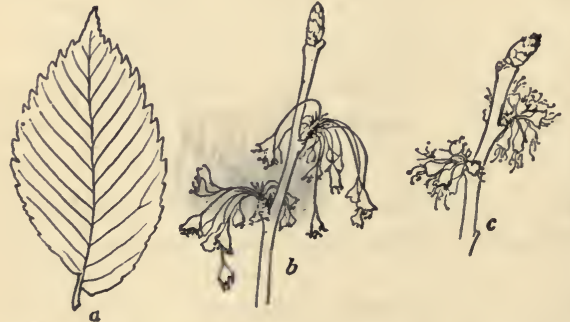

Ulmus americana, American elm; $a$, leaf; $b$, inflorescence; $c$, inflorescence of $U$. fulva, Slippery elm.
U. fulva, Slippery Elm. Flowers nearly sessile. Leaves very rough above. A small or middle-sized tree with tough reddish bark and a very mucilaginous inner bark. Rich soil.

U. americana, AMERICAN Elm, White Elm. Flowers on slender drooping pedicels, appearing before the leaves. Fruit ovate, 
with a fringe. The leaves smooth above or nearly so. A large and well-known ornamental tree, variable in habit. Moist woods, especially along rivers.

\section{CELTIS}

Flowers appear with the leaves and are borne on branches of the same year. They are greenish, axillary, the pistillate ones solitary or in pairs, the lower usually staminate only. Fruit a drupe.

\section{C. occidentalis, HACK-}

BERRY. A small or sometimes large tree with the general appearance of elm. It bears sweet and edible fruits which ripen in autumn and are as large as wild cherries, but the pulp is much thinner. This tree shows much variation as to stature, foliage, form and color of fruit. The fruit is reddish or yellowish and turns dark purple at maturity. The
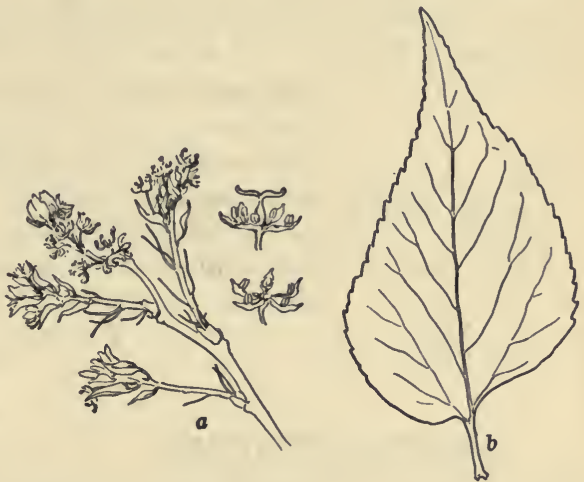

Cellis occidentalis, Hackberry; $a$, inflorescence and individual flowers; $b$, leaf.

leaves are ovate, taperpointed, sharply serrate. Woods and river banks.

\section{MORUS}

A tree with alternate leaves and milky juice. The pistillate and staminate flowers in separate spikes. Leaves dentate, threenerved. Achenes ovate, compressed, covered by the succulent berry-like calyx, the whole spike thus becoming a thickened, oblong, juicy, and edible aggregate fruit.

M. rubra, RED MulberRy. A large tree, ripening its blackberrylike fruit in July. Leaves heart-ovate, serrate, rough above, downy beneath. Flowers frequently dioecious. Fruit dark purple. Rich woods. 


\section{SANTALACEAE (SANDALWoOd Family)}

A small family, chiefly tropical, and including herbs, shrubs and trees.

\section{COMANDRA}

Low herbaceous perennials. The flowers perfect and in umbellike clusters. Anthers connected to the calyx-

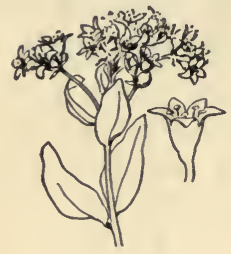
lobes by a tuft of thread-like hairs. A smooth plant with herbaceous stems arising from a rather woody base, alternate and almost sessile leaves, and greenish-white flowers.

C. umbellata, BAstard Toadflax. The flowering stems I.5-4 dm. high, branched, very leafy. The leaves are oblong, thin, pale beneath, the pale

Comandra umbellata,

Bastard toadflax.

Inflorescence and single flower.

midrib being prominent beneath. The inflorescence is an ellipsoid panicle composed of many small flowers on divergent branches. The roots form parasitic attachments to the roots of trees and shrubs. Dry ground. Flowers in May and June.

ARISTOLOCHIACEAE

(BIRTHWORT FAMILY)

A small family of twining shrubs or low herbs, with perfect flowers, the conspicuous calyx valvate in bud and coherent with the 6-celled ovary which forms a many-seeded fruit. Stamens 5-12, more or less united with the style.

\section{ASARUM}

Stemless, perennial herbs. Stamens I2, with more or less distinct filaments. The calyx is 3-parted. The petals when present are rudimentary. The creeping rootstock

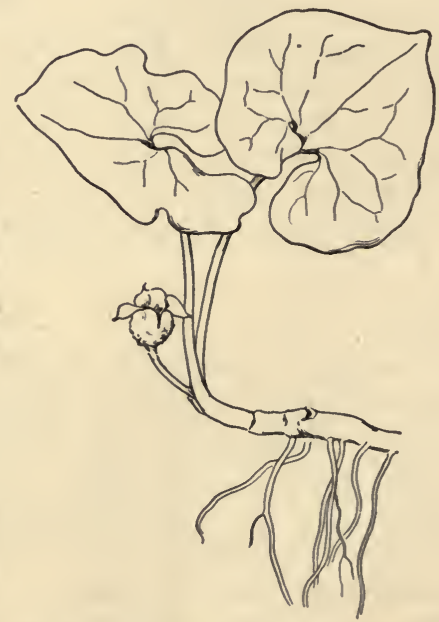

Asarum canadense, Wild ginger. is aromatic-pungent. It bears one or two kidney-shaped or heart- 
shaped leaves on long petioles, and a short-peduncled flower close to the ground in the lower axil. Early spring.

A. canadense, Wild Ginger. Soft pubescent. Leaves kidneyshaped, more or less pointed. Calyx bell-shaped, brown, purple inside. Common in rich woods.

\section{POLYGONACEAE (Buckwheat Family)}

Herbs with alternate entire leaves, and stipules in the form of sheaths above the swollen joints of the stem. The flowers mostly perfect, with a more or less persistent calyx. The fruit is usually an achene, compressed or 3-4 angled or winged.

\section{RUMEX}

Coarse herbs, with small and unattractive flowers, mostly green, crowded and commonly whorled in racemes.

R. acetosella, Field SoRrel. A common low weed, I-3 dm. high. The leaves are narrow-lanceolate or linear, halberd-form, at least the lowermost, the narrow lobes entire and widely spreading. The pedicels are jointed at the summit. The sepals are scarcely enlarged in the fruit, and are exceeded in length by the naked achene. Sterile soil, common.

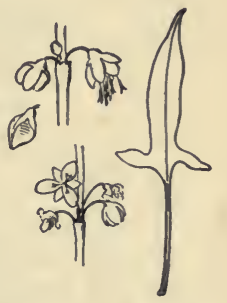

Rumex acetosella, Field sorrel; staminate flowers, pistillate flowers, fruit, and leaf.

\section{CARYOPHYLLACEAE (PiNk FAMILY)}

Herbs with opposite entire leaves, usually 5 sepals (united or separate), 5 petals, io stamens (sometimes fewer), 2-5 styles, and a $\mathrm{I}-$-celled ovary becoming $a$ pod.

\section{ARENARIA}

Low, usually tufted herbs, with sessile leaves and small white flowers. Sepals 5. Petals 5, entire, sometimes barely notched, rarely wanting. Stamens Io. Styles 3 , opposite the sepals. Pod short, splitting into as many or twice as many valves as there 
are styles, few to many-seeded. (Name from arena, sand, in which many of the species grow.)

A. lateriflora, SANDwort. Seeds few. Perennials with broadish leaves. Sparingly branched, minutely pubescent, leaves
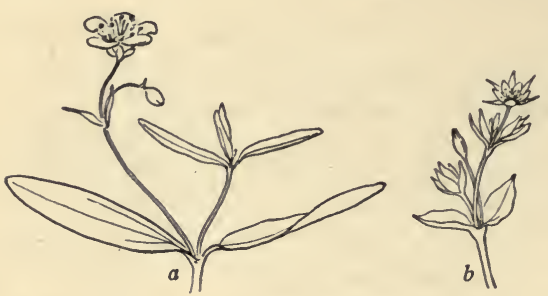

Arenaria; $a, A$. laterifolia, Sandwort; $b, A$. serpyllifolia, Sandwort. ovate, I-2 cm. long. Peduncles 2-flowered. May and June.

A. serpyllifolia, S A N D WORT. Seeds many. Leaves roughish-pubescent. $\mathrm{Th}$ e plant $5^{-15} \mathrm{~cm}$. high. Leaves ovate, small, and acute. Sandy or rocky soil. JuneAugust.

\section{STELLARIA}

Herbs with solitary clustered white flowers. Sepals 4 or 5 and separate, petals 4 or 5 and deeply 2-cleft. Stamens 3-IO. Styles 3. (Name from stella, a star, in allusion to the star-shaped flowers.)

S. media, C H I C K WEED. Stems weak and spreading. Leaves ovate or oblong, the lower on hairy petioles. The petals shorter than the
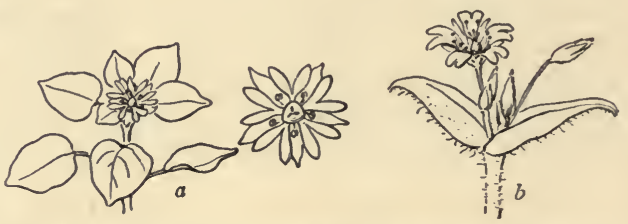

a. Stellaria media, Chickweed, flowering shoot and single flower enlarged; $b$, Cerastium vulgatum, Mouse-ear chickweed.

sepals. Annual or nearly so. A common weed. Introduced from Europe.

\section{CERASTIUM}

Sepals 5, rarely 4. Petals many or 2-lobed, rarely entire, often wanting in some of the flowers. Stamens Io or fewer. Stamens mostly 5, opposite the sepals. The pod often curved, many-seeded. Seeds rough. (Name from keras, a horn, alluding to the shape of the pod.) 
C. vulgatum, Common Mouse-ear Chickweed. Perennial. Petals equaling or shorter than the sepals or wanting. Upper bracts nearly herbaceous. Pedicels longer than the calyx. Common in fields and dooryards. May-July.

C. nutans, Mouse-Ear Chickweed. Annual. Stems erect, slender, grooved, diffusely branched, I.5-5 dm. high. Inflorescence loose, many-flowered. Leaves oblong-lanceolate, acute, the lowest spatulate. Petals a little longer than the sepals. Pods nodding on the stalks, curved upward, nearly or quite three times the length of the calyx. Moist rich soil. May-July.

\section{SILENE}

Herbs with solitary or clustered flowers, a 5toothed calyx, 5 petals with slender stalk-like base, Io stamens, 3 styles, a I-3-celled ovary, and a pod opening at apex by 3 or 6 teeth. (Name from sialon, saliva, from the sticky exudation on the stems and calyx of many species.)

S. antirrhina, Sleepy Catchfly. Annual. Stems slender $(2-9 \mathrm{dm}$. high). Leaves lanceolate or linear. Flowers small, paniculate. Calyx ovoid. Petals obcordate, crowned, opening transiently in sunshine. Common in waste places and open woods. June-Sept.

\section{PORTulacaceae (Purslane Family)}

Herbs with entire fleshy leaves, 2 separate or united sepals, 4 petals, 5-20 stamens, a 2-8 parted style, and a I-celled pod. Corollas opening only in sunshine, mostly ephemeral, then shriveling.

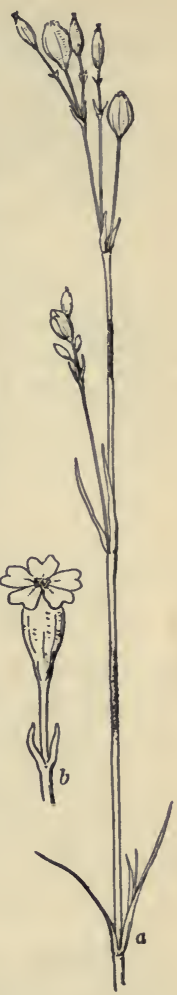

Silene antirrhina, Sleepy catchfly; $a$, habit; $b$, single flower.

\section{CLAYTONIA}

A perennial herb flowering conspicuously and abundantly in spring. The simple stems arise from a small deep tuber. They bear a pair of opposite leaves and a loose raceme of pinkish flowers. The veins of the corolla are more deeply colored than the rest. Sepals 2, ovate, persistent. Stamens 5, adhering to the short 
claws of the petals. Style 3-cleft at the apex. (Named in honor of Dr. John Clayton, one of our earliest botanists.)

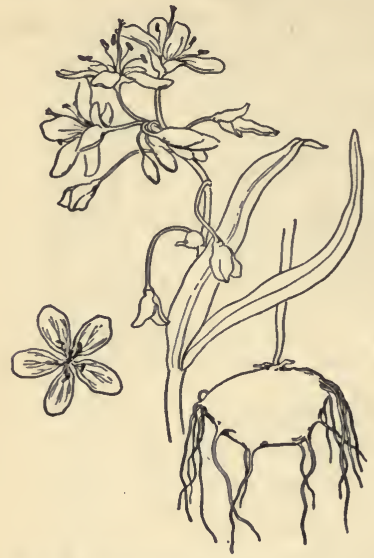

Claytonia virginica, Spring Beauty; habit, corm, and flower.

C. virginica, SPRING BeAuty. Leaves linear-lanceolate, 7-15 cm. long. Moist open woods, common.

\section{NYMPHAEACEAE}

(WA'TER Lily FAMiLy)

Aquatic perennial herbs, with floating leaves. Flowers axillary and solitary.

\section{NYMPHAEA}

Leaves with a deep sinus at the base. Flowers yellow or sometimes tinged with purple, produced all summer. Sepals 5 or 6 or sometimes more, roundish, concave. Petals numerous, small and thickish, stamen-like or scale-like, inserted with the very numerous short stamens on the receptacle under the ovary. Fruit ovoid, naked, usually ripening above the water. (Name formerly used for the white-flowered water-lilies, which were dedicated by the Greeks to the water nymphs.)

N. advena, Yellow Pond Lily. Sepals 6, unequal, yellow, mostly tinged with green or brown. Very common in still or stagnant water.

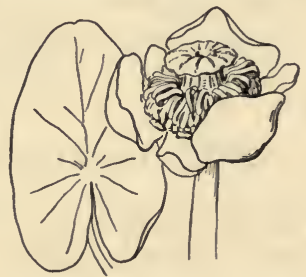

Nymphaea adveria, Yellow pond-lily; flower and leaf.

\section{RANUNCULACEAE (CRowFoot Family)}

Herbs with flower parts all distinct, 3-15 sepals, petals 3-I5 or wanting, stamens numerous or rarely few, and many or few pistils becoming either pods, achenes, or berries. When the petals are wanting the calyx is often colored like a corolla. 


\section{RANUNCULUS}

Annuals or perennials. Stem leaves alternate. Flowers solitary or somewhat corymbed, yellow, rarely white. (A Latin name for a little frog, the aquatic species growing where frogs abound.)

R. aquatilis capillaceus, White WAter Buttercup. Leaves all under water and mostly petioled, their capillary divisions and subdivisions rather long and soft, usually collapsing more or less when withdrawn from the water. Common especially in slow flowing water. Petals white. June-August.

R. delphinifolius, Yellow Water Buttercup. Stems floating or submerged. Leaves all repeatedly 3 -forked into long filiform divisions. Petals 5-8, deep bright yellow, 8-12 $\mathrm{mm}$. long, much larger than the sepals. Carpels in a round head, slightly roughened, beaked, and margined toward the base with a conspicuous border. Quiet water. When rooting out of the water or left in the mud of drying ponds the form becomes modified.
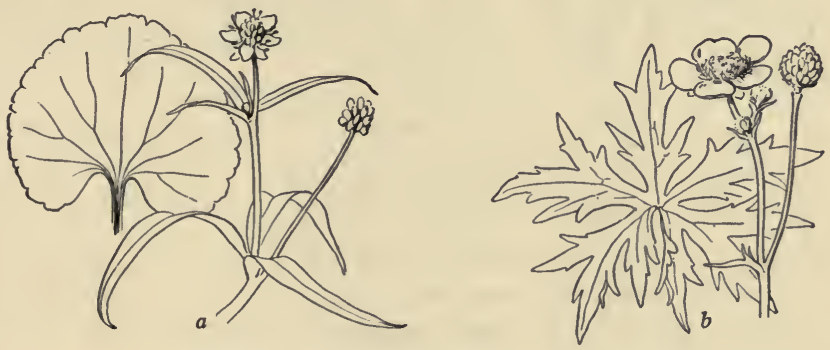

Ranunculus. $a, R$. abortivus; $b, R$. acris.

R. abortivus, Small-Flowered Buttercup. Biennial, slightly succulent. Stem 1.5-6 dm., sparingly-pubescent, primary root-leaves round heart-shaped with a wide shallow sinus. Petals pale yellow, shorter than the small calyx. Shady hillsides and along brooks. Common. April-June.

R. recurvatus, Hairy, 3-6 dm. high. The achenes with a long recurved beak. Root-leaves rarely divided. The achenes in globular heads, compressed, and with margins. The leaves long-petioled, deeply 3-cleft. Large. The petals shorter than the reflexed calyx, pale. Common in woods. May, June.

R. fascicularis, EARLy Buttercup. Low, ascending, I-2.5 dm. high, finely pubescent. The root a cluster of thickened fleshy fibers. Rad- 
ical leaves appearing pinnate, the long-stalked terminal division being remote from the sessile lateral ones. Petals often 6 or 7 and twice the length of the calyx. The carpels scarcely margined, beaked. The style long and attenuate. Petals bright yellow. Dry or moist hills. April and May.

R. septentrionalis, Common Swamp Buttercup. The style long and attenuate. Petals bright yellow. The stems 3-8 dm. long, erect, ascending, or in wet ground some of them procumbent. The lower petioles very long, and the leaves 3-divided. The petals broadly obovate, much larger than the calyx. The carpels strongly margined and beaked. Moist or shady places. May-August.

R. bulbosus. Hairy. Stem $3 \mathrm{dm}$. high, erect from a bulb-like base. The root-leaves 3 -divided, the lateral divisions being sessile, the terminal ones stalked and 3-parted. Petals round and wedge-shaped

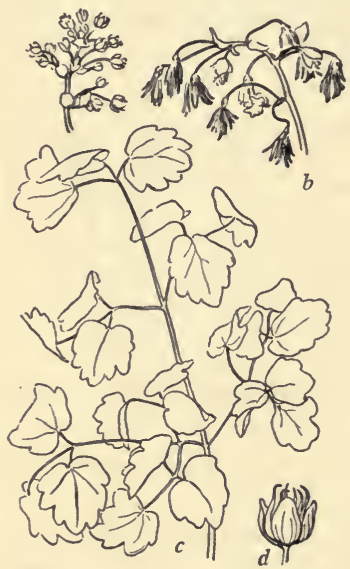

Thalictrum dioicum, Early meadow rue. $a$, pistillate inflorescence; $b$, staminate inflorescence; $c$, leaf; $\cdot d$, single flower.

at base. Calyx reflexed. Carpels with a very short beak. Fields. Abundant in the N. E. and rare west. May-July. The petals often 6 or 7 , deep glossy yellow, the corolla more than $2.5 \mathrm{~cm}$. broad. From Europe.

R. acris, Hairy. Stem erect, 6-9 dm. high. Leaves 3-divided, the divisions all sessile and 3-cleft or parted. The petals obovate, much longer than the calyx. Flowers nearly as large as the preceding species, but not so deeply yellow. Common in fields, especially in the east. JuneAugust. From Europe.

\section{THALICTRUM}

Perennial herbs, with alternate compound leaves, the divisions and the leaflets stalked, and the petioles dilated at the base. Flowers in corymbs, usually dioecious. Sepals 4-5, petallike or greenish and usually disappearing. Petals none. Achenes 4-15.

T. dioicum, Early Meadow Rue. Dioecious. Smooth and pale or glaucous, 3-6 dm. high. The leaflets thin, light green, drooping, 3-7 
lobed. The sepals purplish or greenish white. Common especially in rocky woods and ravines. April-May.

\section{ANEMONELLA}

Low, smooth, perennial. Leaves all radical and compound. Involucre compound at the base of an umbel. Sepals 5-10, white or tinged with pink; conspicuous. Petals none. Achenes 4-15, ovoid, sessile.

A. thalictroides, Rue Anemone. Stem and slender petiole of the radical leaf $\mathrm{I}-3 \mathrm{dm}$. high, rising from a cluster of thickened roots. The leaflets roundish, somewhat 3-lobed, cordate at the base. Flowers several in an umbel. Common in woods.

\section{HEPATICA}

Leaves heart-shaped and 3 -lobed, thickish and persistent through the winter. The new leaves appear after the flowers, the latter occurring singly on hairy scapes. (Name from the resemblance of the leaves to the outline of the liver, hepas.)

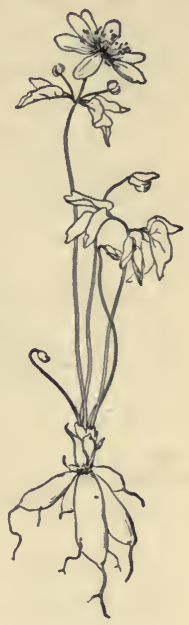

Anemonella thalictroides, Rue anemone.

H. triloba. Leaves with 3 obtuse or rounded lobes. Sepals 6-12, blue, purplish, or nearly white. The achenes numerous in a small loose head, pointed, hairy. Common in woods in early spring.
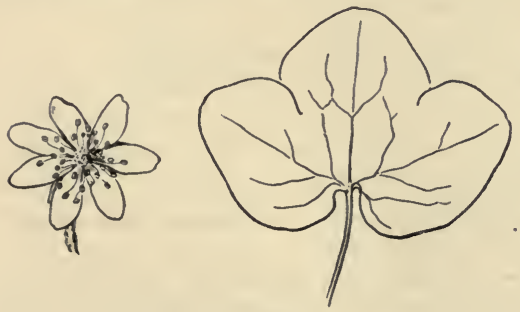

Hepatica triloba.

H. acutiloba. Leaves with 3-pointed lobes or sometimes 5-lobed. The lobes of the involucre also acutish. Merges into the preceding.

\section{ANEMONE}

Perennial herbs with radical leaves, the stem leaves being 2 or 3 together, opposite or whorled, and forming an involucre, remote from the flower. Peduncles I-flowered, solitary or umbellate. The sepals few or many, petal-like. Petals none. (Named from the Semitic 
name for Adonis, from whose blood the crimson-flowered Anemone of the Orient is said to have sprung.)

A. canadensis. Hairy and rather low. The primary involucre is 3-leaved, bearing a naked peduncle, and soon a pair of peduncles with

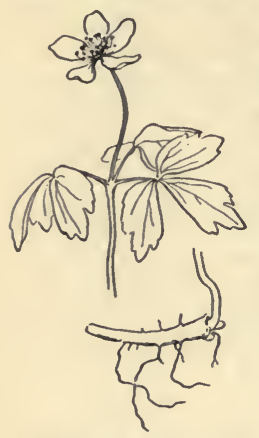
a 2-leaved involucre in the middle, and these branch similarly in turn. The radical leaves 5-7 parted. The sepals white. River banks and prairies.

A. quinquefolia, Wood Anemone. Smooth and rather low. The stem perfectly simple, arising from a root-stalk. The involucre of 3 long-petiolate, trifoliolate leaves. The sepals $4-7$, oval, white, or tinged with purple outside. Margins of woods. April and May.

\section{ISOPYRUM}

Slender, smooth, perennial herbs with 2-3 Anemone quinquefolia, ternately compound leaves; the leaflets 2-3 Wood anemone. lobed. Flowers axillary and terminal, white. Sepals 5, petal-like, deciduous. Stamens 10-40. Pistils 3-6 or more, the styles pointed.

I. biternatum. Fibers of the root thickened here and there into little tubers. Moist and shady woods and cliffs. May.

\section{CALTHA}

Glabrous, hydrophytic perennials with round and heart-shaped large leaves. Sepals 5-9, petal-like. Pistils 5-Io with scarcely any styles.

C. palustris, Marsh Marigold. Swamps and wet meadows in April and June. The stem is hollow and furrowed. The sepals are

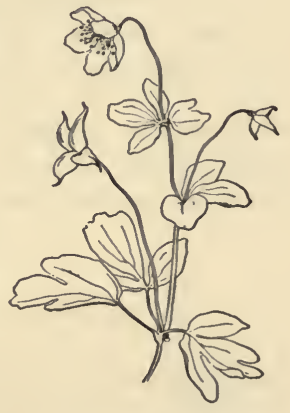

Isopyrum biternatum. broadly oval and bright yellow. Sometimes used for greens when young. The brilliant golden yellow flowers resemble buttercups and are often wrongly called cowslips.

\section{COPTIS}

A low, smooth perennial with divided root-leaves, and small 
white flowers on scapes. Sepals $5-7$, petal-like, deciduous. Petals 5-7, small, club-shaped, hollow at the apex. Stamens I5-25. Pistils 3-7 on slender stalks. (Named from coptein, to cut, referring to the divided leaves.)

C. trifolia, Goldthread. A tiny woodland plant whose long bright yellow and thread-like roots are thought to have medicinal value.

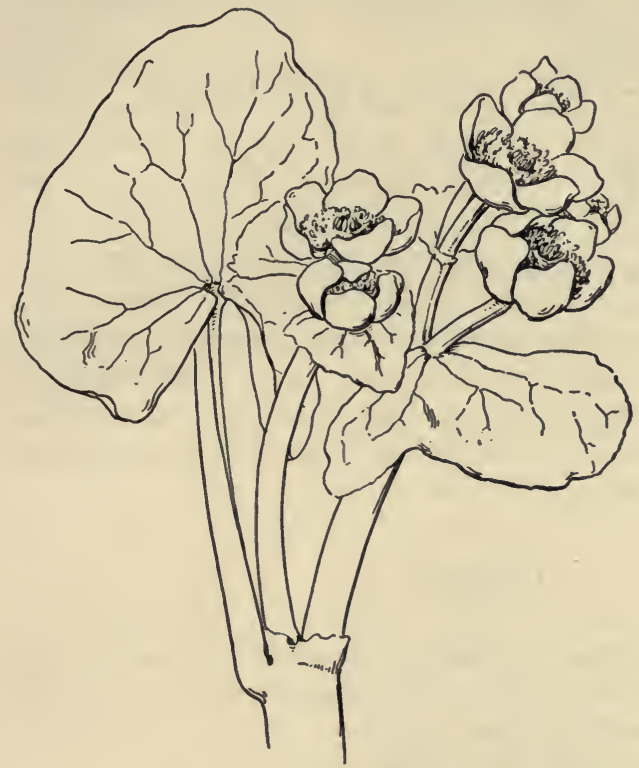

Caltha palustris, Marsh marigold.

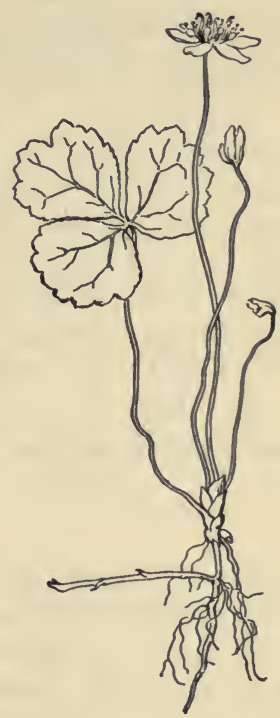

Coptis trifolia, Goldthread.

They are bitter. The evergreen leaves are dark green and shining, 3-lobed, scalloped, finely toothed, long-stemmed. Mossy woods and swamps. May-July.

\section{AQUILEGIA}

Perennials with 2-3 ternately compound leaves, the leaflets lobed. Flowers large and showy, terminating the branches. Sepals 5, regular, colored like the petals. Petals 5, all alike, with a short spreading lip, and extending backward into large spurs which are much longer than the calyx. Pistils 5, with slender styles. 
A. canadensis, Columbine. Delicate in appearance but hardy, being common on rocky hillsides. The long-stemmed compound leaves are light olive green. The flowers grade in color from yellow through scarlet to red at the tip of the spurs; they nod on their pedicels so that the spurs turn upward, but the pedicel becomes erect when the

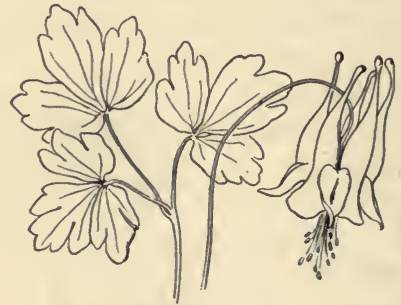

Aquilegia canadensis, Columbine.

fruit is ripe. The long spurs indicate the relation of the flower to longtongued insects. April to June.

\section{DELPHINIUM}

The showy flowers are in terminal racemes. The leaves are palmately divided or cut. The five sepals are irregular and petal-like, the upper one being prolonged into a spur at the base. The petals are four and irregular, the upper pair being continued backward into long spurs which are enclosed in the spur of the calyx. (Named from Delphin, referring to the shape of a flower, which is not unlike the conventional outline of a dolphin.)

\section{ACTAEA}

Perennials, with broad, 2-3 ternately compound leaves, the ovate leaflets sharply cleft and toothed. The white flowers occur in a short and thick terminal raceme. The sepals are 4 or 5 , falling off when the flower expands. The petals are 4 to Io, small, flat, and on slender claws. The stamens are numerous and have slender white filaments. The pistil is single, the stigma being sessile and 2-lobed.

A. alba, White Baneberry. The globular berries are white, the pedicels which bear them becoming thickened in fruit, as

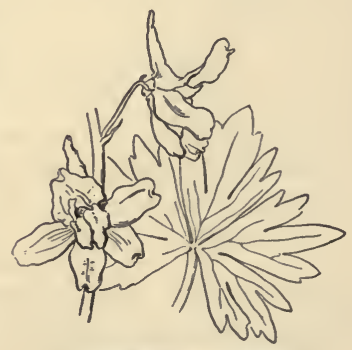

Delphinium, Larkspur. large as the peduncle, and red. The raceme is ellipsoid and the petals slender, appearing to be transformed stamens. Common in rich woods in April and May. 


\section{MAGNOLIACEAE (Magnolia Family)}

Trees or shrubs, the leaf buds covered by membranous stipules. The calyx and corolla colored alike, and imbricated in the bud. The leaves alternate, not toothed, and marked with minute transparent dots. The flowers single and large.

\section{MAGNOLIA}

Sepals 3. Petals 6-9. Pistils coherent, forming a fleshy and rather woody, cone-like, red fruit. Each carpel at maturity opens on the back.

M. acuminata, Cucumber TREe. A tree $18-27 \mathrm{~m}$. high, the fruit when young slightly resembling a small cucumber. The leaves are thin, oblong, pointed, green, and a little pubescent beneath, $13-25 \mathrm{~cm}$. long. The flower is shaped like a slender bell, and is green tinged with yellow, $5 \mathrm{~cm}$. long. The cone-like fruit is cylindrical. Rich woods. May-June.

\section{LIRIODENDRON}

A beautiful tree sometimes $40 \mathrm{~m}$. high and 2-3 $\mathrm{m}$. in diameter. The timber is commonly called poplar or whitewood. (Named from lirion, lily, and dendron, tree.)

L. Tulipifera, Tulrp TREe. Leaves very smooth with 2 lobes near the base and 2 at the apex. Sepals 3, reflexed. Petals 6, in two rows, making a bell-shaped corolla. Anthers, linear, opening outward. Carpels flat, narrow, and coherent in an elongated cone which falls away whole. The petals are $5 \mathrm{~cm}$. long, greenish-yellow marked with orange. Rich soil. May-June.

\section{anonaceae (Custard Apple Family)}

A tropical family except for the following genus. Trees or shrubs.

\section{ASIMINA}

Shrubs or small trees with unpleasant odor when bruised. The deep red flowers occur singly in the axils of last year's leaves. Petals 6, the outer set larger than the inner. Stamens numerous 
and in a globular mass. Carpels few, ripening into I-4 large thick-cylindrical, pulpy fruits. Seeds several, flat.

A. triloba, PAPAw. Leaves thin, obovate-lanceolate, pointed. The petals round-ovate. Tree $3^{-12} \mathrm{~cm}$. high. The flowers appear with the

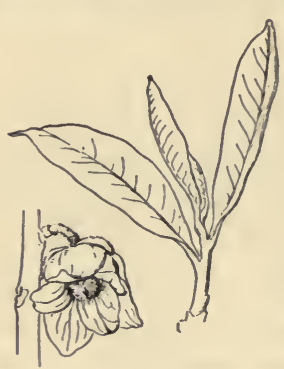

Asimina triloba, Papaw.

leaves. The fruits are $7-13 \mathrm{~cm}$. long, green, turning brown, the pulp being sweet and edible in autumn. Banks of streams and rich soil. April-May.

\section{BERBERIDACEAE (BARBERRY FAMILY)}

Shrubs or herbs. Leaves alternate. Fruit $a$ berry or a pod.

\section{PODOPHYLLUM}

Perennial herbs, with creeping root-stalks and thick, fibrous roots. Sepals 6, falling early. Petals 6 or 9, obovate, white. Stamens twice as many as the petals. Ovary ovoid, with a large sessile stigma. Fruit a large, fleshy berry. Stems 2-leaved and I-flowered. (Name from pous, foot, and phullon, leaf, probably referring to the thick petioles.)

P. peltatum, May Apple. The flowerless stems are terminated by a large round 7-9 lobed leaf, umbrellalike. The flowering stems bear 2 onesided leaves and a nodding white flower at the fork. Flowers in May and ripens fruit in July. The fruit is edible. Common in rich woods.

\section{CAULOPHYLLUM}

A perennial glabrous herb with knotty rootstalks. It

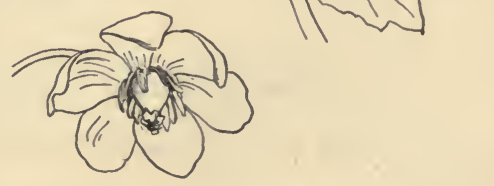

Podophyllum peltatum, May apple. sends up in early spring a simple and naked stem which is terminated by a small inflorescence of yellowish-green flowers and bears a little below the inflorescence a large compound sessile leaf. Sepals 6 , with 3 or 4 
bractlets at the base. The petals are replaced by 6 somewhat kidney-shaped bodies, much smaller than the sepals, and one at the base of each sepal. The ovary bursts soon after flowering, due to the pressure of the 2 enlarging seeds. The spherical seeds stand naked on their thick stalks, the fleshy integment turning blue. (Named from kaulos, stem, and phullon, leaf.)

C. thalictroides, Blue Coнosh. The flowers appear while the leaf is yet small. The stems are $3-7.5 \mathrm{dm}$. high. The leaflets are obovate and 2-3 lobed. Deep rich woods. April-May.

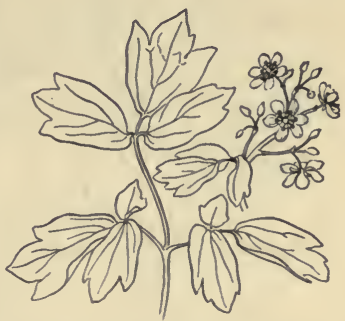

Caulophyllum thalictroides, Blue cohosh.

\section{BERBERIS}

Shrubs with yellow wood and inner bark, yellow flowers in drooping racemes, sour berries, and $I-9$ foliolate leaves.

B. vulgaris, BARBERry. Sepals 6 , roundish, with $2-6$ bractlets outside. Petals 6, obovate, having 2 glandular spots inside. Stamens 6. Stigma circular and depressed. The fruit a I-few seeded berry. The leaves of the fresh shoots are scattered and are mostly reduced to spines, from the axils of which fascicles of leaves arise the next season, as well as the drooping many-flowered racemes. The berries are ellipsoid and scarlet. Thickets and waste ground. May and June. Introduced from Europe.

\section{LAURACEAE (LAUREL Family)}

Aromatic trees or shrubs, with alternate simple lcaves, mostly marked with minute dots. The flowers have a regular calyx of 4 or 6 colored sepals, and are clustered.

\section{SASSAFRAS}

Trees with spicy aromatic bark and entire or lobed leaves. The flowers are greenish-yellow, and naked. They appear with the leaves in clustered racemes. Dioecious. The staminate flowers have 9 stamens inserted on the base of the calyx in three rows. 
The pistillate flowers have 6 short rudiments of stamens and an ovoid ovary. The fruit is a blue drupe borne on a club-shaped

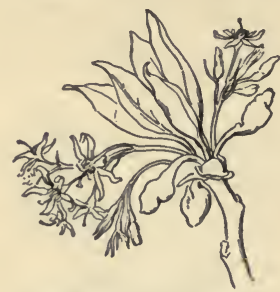

Sassafras variifolium, Sassafras. pedicel.

S. variifolium, Sassafras. Trees 4-28 m. high, with yellowish-green twigs, leaves ovate, entire, or some of them 2 or 3 lobed. Frequent in woods. April.

\section{BENZOIN}

A shrub with yellow flowers in almost sessile umbel-like clusters, which appear before the leaves. The clusters are composed of smaller clusters each of 4-6 flowers and surrounded by an involucre of 4 deciduous scales. Leaf buds scaly. Easily recognized by the odor of its broken leaves, which resembles that of benzoin, an oriental gum.

B. aestivale, SPICE Bush. 'The flowers are polygamo-dioecious. The fruit is a red drupe. The plant is 2-5 $\mathrm{m}$. high, the leaves being oblongobovate, pale underneath. Damp woods. March-April.

\section{PAPAVERACEAE}

(Poppy Family)

Herbs with milky or colored juice. Leaves alternate and without stipules. Regular flowers with the parts in twos or fours. Sepals fugacious. Petals 4-12, spreading, imbricated and often crumpled in
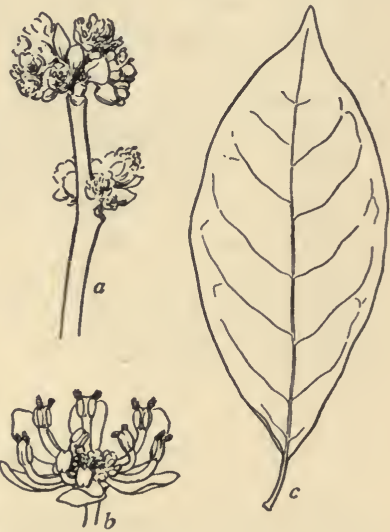

Benzoin aestivale, Spice bush. $a$, inflorescence; $b$, flower; $c$, leaf. the bud's, early deciduous. Stamens many and distinct. Fruit a dry pod. Seeds numerous.

\section{SANGUINARIA}

A low perennial. Its thick horizontal root-stalks have a redorange juice. They send up in earliest spring a palmate-lobed 
leaf and a I-flowered scape. The bud is erect and the flower white and handsome. (Name from the color of the juice.)

S. canadensis, Blooproot. Sepals 2. Petals 8-12. Stamens about 24. Style short. Stigma 2-grooved. Pod ellipsoid. Seeds with a large crest. Common in open rich woods. AprilMay.

\section{STYLOPHORUM}

A perennial low herb. The naked stems bear at the top 2 opposite leaves and a I-fewflowered umbel. Leaves pinnately parted or divided. Juice yellow.

S. diphyllum, Celandine Poppy. Sepals 2, hairy. Petals 4. Style distinct, columnar. Pods bristly. Seeds conspicuously crested. Leaves pale beneath, deeply pinnatifid into 5 or 7 oblong divisions. Damp woods. May.

\section{FUMARIACEAE (Fumitory FAMily)}

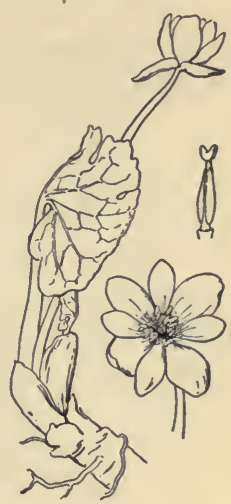

Sanguinaria canadensis, Bloodroot.

Delicate smooth herbs with thin juice, compound dissected leaves, irregular flowers, with 4 somewhat united petals, and 6 diadelphous stamens. The leaves are delicate,

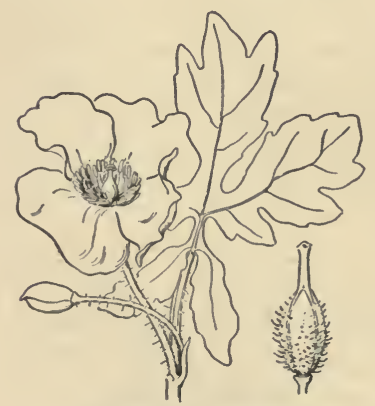

Stylophorum diphyllum, Celandine poppy. usually alternate, and without stipules.

\section{DICENTRA}

Low stemless perennials with ternately compound leaves and racemose nodding flower. The petals cohere slightly, forming a heart-shaped or 2-spurred corolla. (Name from dis, twice, and kentron, a spur.)

D. Cucullaria, Dutchman's Breeches. A very delicate plant having a cluster of grain-like tubers crowded together in the form of a bulb. From this arise in early spring the finely cut leaves and the slender scape which bears 4-ro flowers. The flowers are white, tipped with cream color. The 
2 divergent spurs of the corolla are longer than the pedicel and the crest of the inner petals is minute. Frequent in rich woods.

D. canadense, Souirrel CorN. Similar to the foregoing in general aspect but with many distinctive characteristics. The root-stalks bear scattered grain-like tubers. The corolla is heart-shaped, the spurs being very short and $\mathrm{r}$ ounded. The crest of the inner petals is conspicuous. The flowers are greenish-white, tinged with pink, and have the fragrance of hyacinths. Rich woods. April-May.

\section{CRUCIFERAE (Mustard Family)}

Herbs with a thin and pungent juice, and 4-parted, regular flowers. Sepals 4 and deciduous. Petals 4, hypogynous, their spreading limbs forming a cross. Stamens 6, two of the $m$ inscrted lower than the others and shorter. Leaves alternate; stipules none. Flowers in

Dicentra. $a, D$. cucullaria; $b$, underground stem; $c$, flower of $D$. canadense; $d$, underground stem.

terminal racemes or corymbs. A large and natural family.

\section{DRABA}

Low, pubescent herbs with entire or toothed leaves and white or yellow flowers. 
D. caroliniana, Whitlow Grass. Small, $2.5-12 \mathrm{~cm}$. high; petals usually twice the length of the calyx; pods broadly linear and smooth, much longer than the ascending pedicels. Sandy and waste fields. March to May.

\section{LEPIDIUM}

Small plants with simple leaves, small white or greenish flowers, and a roundish pod much flattened in a direction opposite to the narrow partition.

L. virginicum, Wild PepPergrass. Leaves with tapering base, the upper linear or lanceolate and entire, the lower incised or pinnatifid; the orbicular or oval pods with a small notch at the top; stamens only 2. Common along roadsides. June to September.

L. apetalum, Peppergrass. Pod orbicular and minutely wingmargined at the top. Petals usually wanting. Dry places, especially roadsides.

\section{CAPSELLA}

Low annual plants with clustered pinnatifid basal leaves, and arrow-shaped sessile stem leaves. The raceme of small white flowers continues to elongate through the season. The pod is triangular and flattened in a direction opposite to that of the narrow partition. Seeds numerous.

C. Bursa-pastoris, S H E P H ER D's Purse. A very common weed, extremely variable in foliage and in outline of the pod, whose shape gives it its common name. April to Sept.

\section{BRASSICA}

Annuals or biennials with yellow flowers. The lower leaves are in-
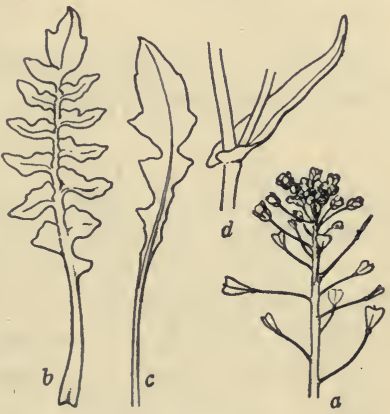

Capsella Bursa-pastoris, Shepherd's purse; $a$, flowers and fruit; $b$, root leaf; $c$, stem leaf; $d$, clasping upper leaf. cised or pinnatifid.

B. arvensis, Charlock. A frequent and injurious weed in grain fields. The knotty pods are fully one-third occupied by a stout 2-edged beak. The upper leaves are scarcely petioled and are merely toothed. 
The fruiting pedicels are short and thick and the pods are smooth, 4 $\mathrm{cm}$. long. Introduced from Europe.

B. nigra, Black Mustard. Leaves slender, petioled and somewhat hairy, the lower ones having a very large terminal lobe and a few small lateral ones. The pods short, I.5-1.8 cm. long, on short erect pedicels, flattened. The seeds are dark and very pungent. Common along roadsides and in waste places. Introduced from Europe.

\section{BARBAREA}

Mostly biennials. Flowers yellow. Pods linear, round or somewhat 4-sided.

B. vulgaris, Winter Cress. A smooth perennial. The lower leaves lyrate, the terminal division round and usually large. The lateral divisions I-4. The upper leaves obovate, cut-toothed, or pinnatifid at the base. Flowers bright yellow. Pods erect or ascending on spreading pedicels. Low grounds and roadsides.

\section{DENTARIA}

Herbs with long, horizontal, fleshy and pungent rootstocks. Simple stems naked, below and bearing 2 or 3 petioled, compound

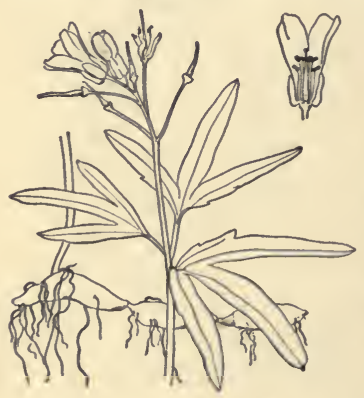

Dentaria laciniata, Toothwort. leaves about or above the middle, and terminated by a single cluster of large white or purple flowers, and lanceolate flat pods.

D. diphylla, Toothwort. Rootstock long and continuous, often branched; stem-leaves 2, similar to the basal ones; leaflets rhombic-ovate or oblong-ovate, coarsely crenate, the teeth abruptly acute; flowers white. Rich woods.

D. laciniata, TоотнWORT. Rootstock tuberous, deep-seated; basal leaves, often none; stem-leaves 3-parted, the lateral segments often 2-lobed, all broadly oblong to linear, more or less gash-toothed; flowers white or rose-color. Rich woods. 


\section{CARDAMINE}

Herbs with fibrous roots, sometimes tuber-bearing. Stems leafy, with alternate, simple or compound leaves, and bearing a cluster of white or purple flowers and linear flat pods.

C. bulbosa, Spring Cress. Stem smooth, from a tuberous base and a slender rootstock bearing small tubers; root-leaves oblong to heart-shaped, stem-leaves 5-8, scattered, becoming narrower above, often toothed; flowers white. In wet meadows and around springs. May, June.

C. Douglasii, Spring Cress. Like the last, but stem usually pubescent, root-leaves orbicular, and flowers rose-purple. Rich woods. April, May.

C. pennsylvanica, Pennsylvania Bitter Cress. Stem from fibrous roots, usually smooth, and bearing pinnate leaves with 7-II leaflets; terminal leaflet obovate, lateral ones oblong; flowers small, white. Moist places.

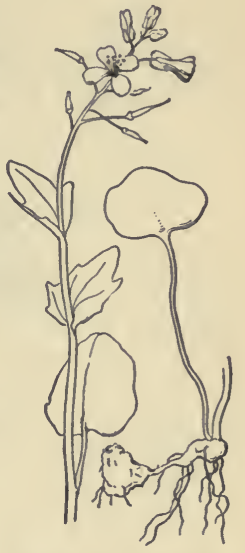

Cardamine Douglasii, Spring cress.

Stem from fibrous roots, with no tubers, bearing alternate simple or pinnatifid leaves, a cluster of white or purple flowers, and linear flat pods.

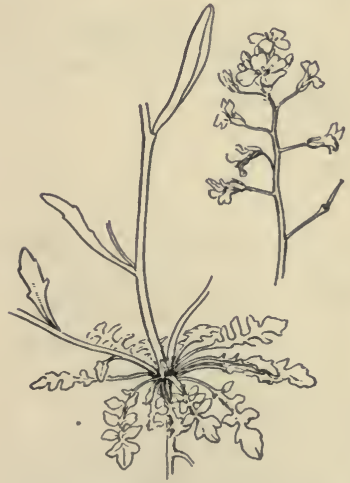

Arabis lyrata, Rock cress.

A. lyrata, Rock CRess. Branching from the base, smooth except the lyratepinnatifid root-leaves; stem leaves scattered, narrow, with tapering base, toothed or entire; flowers white, the petals much longer than the sepals. On rocks or sandy places. April to July.

A. laevigata, Sмоотн Rock CRess. Stems simple and very leafy, with rootleaves rarely lyrate, and narrow stem leaves, mostly toothed and partly clasping by an arrow-shaped base; flowers white and small, the petals scarcely longer than the sepals. Rocky places. May. 


\section{SAXIFRAGACEAE (SAXIFRAGE FAMiLy)}

Herbs or shrubs with alternate or opposite leaves, with or without stipules. Stamens 5-I0. Fruit either a capsule or berry.

\section{SAXIFRAGA}

Herbs with clustered root-leaves, white flowers, Io stamens, and 2-beaked capsules which sometimes become almost separate.

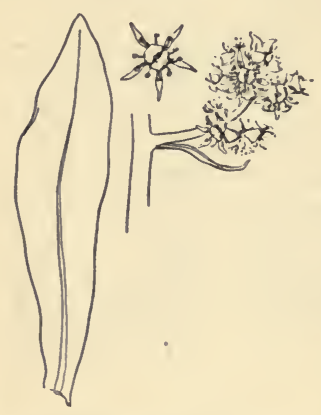

Saxifraga pennsylvanica, Swamp saxifrage.

S. pennsylvanica, Swamp Saxifrage. A large plant becoming as much as $6 \mathrm{dm}$. high ; large, lanceolate, obscurely-toothed leaves; flowers in a large oblong cluster, and divisions of the capsule at length divergent. Low meadows.

S. virginiensis, Early Saxifrage. A low plant from 1.5-3 dm. high; obovate, crenate, toothed leaves; flowers in an open cluster; and the two divisions of the capsule united only at base, divergent, purplish. On rocks and dry hillsides. April to June.

\section{TIARELLA}

Low herbs with root-leaves, and usually leafless stems. Small, white flowers in racemes. Petals entire. Stamens Io, long and slender. Ovary one-celled.

T. cordifolia, FALSE Mitrewort. Leaves rising from a rootstock or from runners, heart-shaped, lobed and toothed, downy beneath; stem I-4 dm. high, rarely with one or two leaves. Rich woods, April to June.

\section{HEUCHERA}

Herbs with round, heart-shaped root-leaves. Flowers in small clusters, greenish or purplish. Petals small, entire. Stamens 5 .

H. americana, Alum Root. Stems 6-9 dm. high, glandular and hirsute with short hairs; calyx regular, $3-6 \mathrm{~mm}$. long; petals about as long as its lobes. Rocky woods.

H. hispida, Alum Root. Stems 5-12 dm. high, hispid or hirsute with long spreading hairs, scarcely glandular; calyx $6-8 \mathrm{~mm}$. long; stamens longer than petals. Woods. 


\section{MITELLA}

Low herbs with round, heart-shaped leaves and mostly naked flowering stems; flowers in a slender raceme. Petals small, pinnatifid. Ovary one-celled.

M. diphylla, Bishop's CAP. A hairy plant, with heart-shaped, acutely lobed leaves, those on the stem two and opposite, nearly sessile; flowers white, in a raceme $1.5-2 \mathrm{dm}$. long. Rich woods. May.

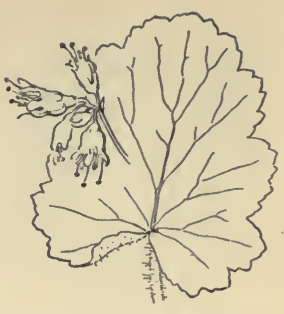

Heuchera hispida, Alum root.

\section{RIBES}

Low and sometimes prickly shrubs with alternate, palmately lobed leaves. Flowers small, clustered. Fruit a berry crowned

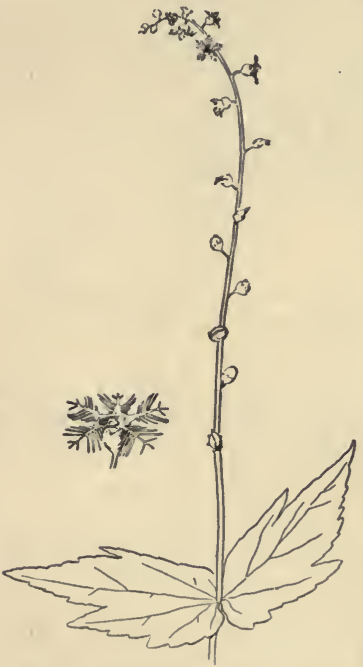

Mitella diphylla, Bishop's cap. with the remains of the calyx.

R. Cynosbati, Prickly Gooseberry. A spiny shrub, often with bristly prickles, 0.5-I cm. long; leaves pubescent; calyx broadly bell-shaped; berries armed with long spines. Rocky woods. April to June.

R. oxyacanthoides, Sмоотн GooseBERRY. A spiny shrub, spines $3-8 \mathrm{~mm}$. long; leaves smoothish; flowers greenish, purple, or white; calyx broadly oblong; berries smooth, or sometimes with whitish prickles. The common northern gooseberry. May to June.

R. floridum, Wild Black Currant. An unarmed shrub with lobed leaves, doubly serrate, and with resinous dots beneath; racemes of large yellow and whitish flowers, drooping and downy; calyx tubular, bell-shaped, smooth. Rich woods. April to May.

\section{Platanaceae (Plane Tree Family)}

Trees with alternate, palmately-lobed leaves, and monoecious naked flowers in separate and naked spherical heads. 


\section{PLATANUS}

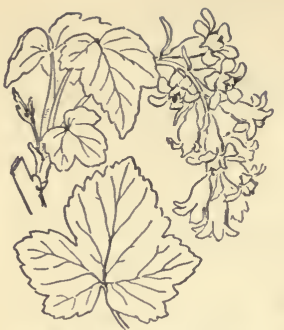

Ribes floridum, Wild black currant.

Large trees with outer bark peeling off in thin plates. The leaves with petioles, hollow at base, and enclosing a bud of the next season. Fruit club-shaped, one-seeded nutlets with a ring of bristly hairs at base.

P. occidentalis, Sycamore. A tree reaching $40 \mathrm{~m}$. in height with a trunk sometimes over $4 \mathrm{~m}$. in diameter; leaves mostly truncate at base, sinuate-lobed, the lobes sharp-pointed; fertile heads solitary, hanging on long peduncle, persistent through the winter. Usually along streams in rich soil. May.

\section{ROSACEAE (Rose FAMily)}

Trees, shrubs, or herbs with regular flowers. St a mens usually numerous, inserted on the calyx. One to many carpels, which are distinct or united, and alternate leaves.

\section{PHYSOCARPUS}

Shrubs with simple, palmately lobed leaves and umbels

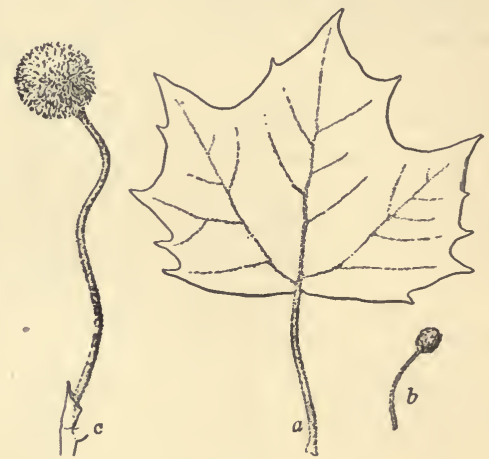

Platanus occidentalis, Sycamore; $a$, leaf; $b$, staminate inflorescence; $c$, pistillate inflorescence. of white flowers. 30 to 40 stamens. I to 5 pods, inflated.

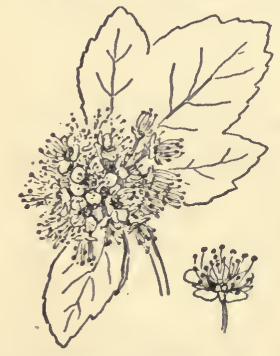

Physocarpus opulifolius, Nine-bark.

P, opulifolius, Nine-BARK. Shrub i to $3 \mathrm{~m}$. high. Branches long, roundish; leaves 3-lobed, heart-shaped; pods usually 3 , purplish, membranaceous. River banks and rocky places. June.

\section{PYRUS}

Trees or shrubs with showy flowers in corymbs or umbels. Stamens numerous. Carpels adnate. Calyx tube and fruit fleshy (pome). 
P. coronaria, WILd CRAB. Tree 6 to Io $\mathrm{m}$. high. Leaves ovate or elliptic, rounded at base, and persistent; calyx lobes becoming smooth; fruit greenish-yellow. Thickets and open woods. April and May.

P. arbutifolia, Chokeberry. Shrub I to 3 m. high. Leaves oblong-oblanceolate, acute, serrate, tomentose beneath; pedicels, calyx and young fruit tomentose; ripe fruit red. Swamps and low woods. March to May.

P. americana, Mountain Ash; Trees or

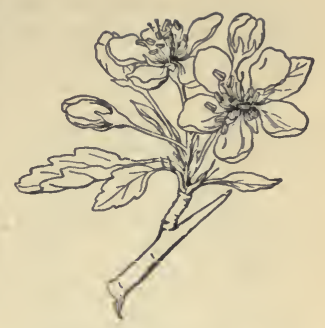

Pyrus coronaria, Wild crab. tall shrubs, nearly smooth. Leaves pinnate; leaflets I3 to I5, lanceolate, taper-pointed, serrate; fruit berry-like, bright red, about the size of

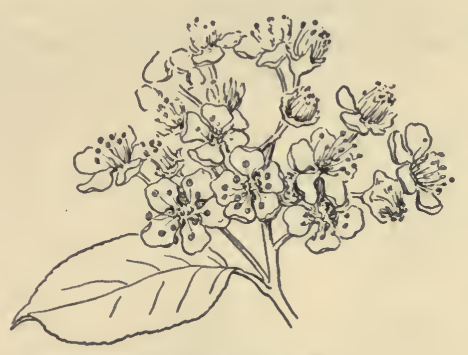

Pyrus arbutifolia, Chokeberry. large peas. Woods. May and June.

\section{AMELANCHIER}

Small trees or shrubs with smooth leaves, white flowers in racemes. Stamens numerous; carpels 5 ; the berrylike pome Io-celled on account of false partitions.

A. canadensis, SER V I C E BERRY. Trees or shrubs 3 to $12 \mathrm{~m}$. high. Leaves ovate, usually cordated base, pointed finely and sharply serrate; flowers large, in drooping racemes; petals narrowly oblong, 15 to 25 $\mathrm{mm}$. in length; fruit crimson or purplish. In dry woods. March to May.

A. oblongifolia, Shadbush. Shrubs or small trees, 2 to $6 \mathrm{~m}$. high. Young leaves and racemes white, tomentose; leaves oblong, usually rounded at each end, finely serrate; flowers numerous, in dense racemes; petals obovate or oblong, 5 to ro $\mathrm{mm}$. in length. Moist woods and rocky grounds. April, May.

\section{CRATAEGUS}

Shrubs or small trees, usually spiny, with

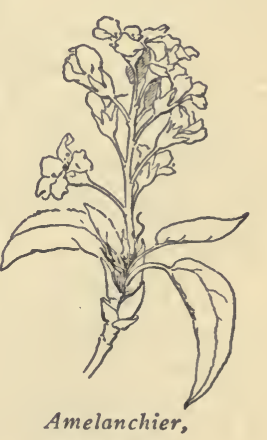

Service berry. 
simple, usually lobed leaves and white or pink flowers, in corymbs. Inferior ovaries, and small pomes of various colors.

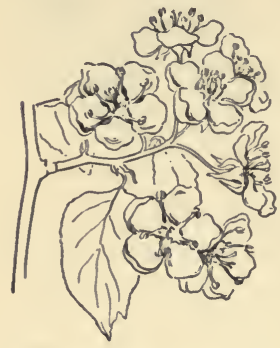

Crataegus, Red haw.

C. coccinea, RED HAw. Shrubs or small trees with stout spines, 3 to $5 \mathrm{~cm}$. long. Petioles long, slender; blades broadly ovate to orbicular, rough, pubescent, pointed at apex, sharply cut and serrate; fruit usually pubescent, yellowish-green, becoming dark reddishbrown. Thickets. April, May.

\section{FRAGARIA}

Stemless shrubs with runners. Leaves with three wedge-shaped leaflets and clusters of white flowers on naked stems. Fruit the pulpy scarlet receptacle bearing minute achenes scattered over its surface.

F. virginiana, Wild Strawberry. Flower cluster with a flattish top, calyx lobes tending to be connivent about the young fruit; achenes in pits and the pulpy receptacles. Moist rich woods and fields. April to June.

F. vesca americana, Wild StrawBERRY. Flower cluster soon regular and becoming raceme-like; calyx lobes loosely spreading or reflex, early exposing the fruit; achenes superficial or nearly so on the receptacle. Rocky woods. May, June.

\section{POTENTILLA}

Shrubs with compound leaves. Flowers solitary or in clusters, with

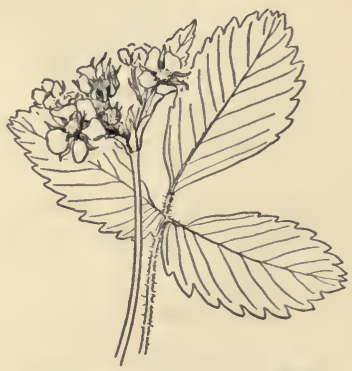

Fragaria virginiana, Wild strawberry.

numerous stamens and carpels, collected in a head on the dry receptacle.

P. monspeliensis norvegica, Rough CinQUefoll. Stout, erect, hirsute, reaching $9 \mathrm{dm}$. in height; leaflets 3 , oblong; those of the uppermost 3 to 5 toothed near the end. Flowers small with yellow petals and 5 to 20 stamens. Open ground. May to August.

P. argentea, Silvery Cinguefoil. Stems ascending, reaching $5 \mathrm{dm}$. 
in length, branched at the summit, white, woolly; leaflets 5, wedgeshaped, more or less pinnatifid, silvery-white beneath; flowers rather large with yellow petals; stamens 20. Barren fields. June to September.

P. Anserina, Silver Weed. Perennial, spreading by slender runners; leaves white, tomentose, silky villous; young radical ones pinnate; leaflets 7 to $2 \mathrm{I}$, oblong; peduncles axillary, one-flowered. Marshes and river banks. June to August.

P. canadensis, COM M ON Cinqueforl. Somewhat erect, becoming $7 \mathrm{dm}$. high or procumbent. Stem hirsute bearing solitary flowers on axillary peduncles; leaves with 3 leaflets, which are apparently 5 on account of the parting of the lateral leaflets; leaflets oblong, serrate, more or less hairy beneath. Sandy soil. May to July.

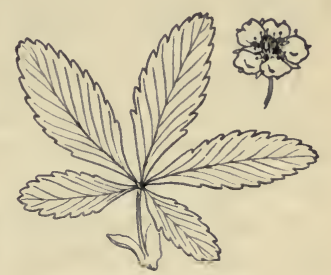

Potentilla canadensis, Common cinquefoil.

\section{ROSA}

Shrubs, usually prickly, with pinnate leaves, conspicuous stipules and urn-shaped calyx tube. Petals are broad and numerous with

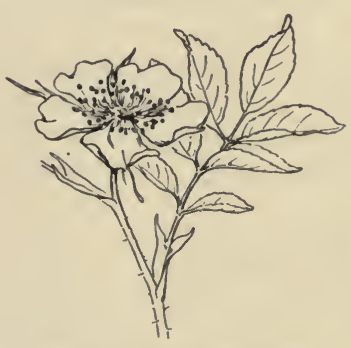

Rosa blanda, Wild rose. stamens inserted on the edge of the tube, and hairy ovaries becoming hard achenes.

R. blanda, WiLd Rose. Stems becoming $15 \mathrm{dm}$. high, unarmed, or occasionally with prickles; stipules dilated; leaflets 5 to 7 , oblong-lanceolate, wedge-shaped at base; flowers large clustered or solitary; sepals hispid, entire; sepals connivent afflowering, persistent. Rocks and beaches.

R. carolina, Swamp Rose. Stems becoming $25 \mathrm{dm}$. high, with stout, often curved prickles; stipules long and very narrow; leaflets 5 to 9 , narrow, oblong, and acute at each end; sepals spreading after flowering, falling from the mature fruit. Borders of swamps and streams.

R. humilis, Pasture Rose. Stems low, not exceeding $9 \mathrm{dm}$. in height, with straight, slender prickles; stipules narrow; leaflets mostly 7, smooth; flowers often solitary; sepals spreading after flowering, outer ones more or less lobed. Dry soil, or on rocky slopes. 


\section{PRUNUS}

Small trees or shrubs with 5 -cleft calyx, 5 spreading petals, I5 to 20 stamens, and a solitary pistil which becomes a fleshy drupe.

P. serotina, Wild Black CherRy. Large tree with reddish-brown branches, the inner bark aromatic; leaves oblong or lanceolate, taperpointed, serrate, with short incurved teeth; flowers in racemes; fruit purplish-black. Woods.

P. virginiana, Chokecherry. Shrub or small tree with grayish bark, inner layers with a disagreeable odor; leaves oval to obovate, abruptly pointed, very sharply serrate, with slender teeth; fruit red turning to dark crimson. Woods.

P. pennsylvanica, Wild Red Cherry. Tree 6 to io $\mathrm{m}$. high, with light red-brown bark; leaves oblong, lanceolate, pointed, sharply

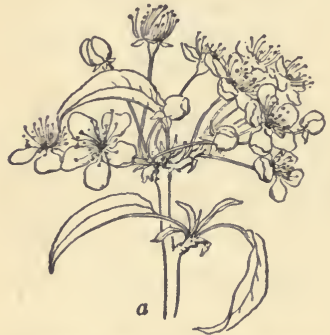

Prunus; $a, P$. pennsylvanica, Wild red cherry; $b, P$. pumila, Sand cherry. serrate, shining, green, and smooth on both sides; flowers numerous, in umbel-like clusters; fruit light red, very small. Rocky woods and clearings.

P. pumila, Sand Cherry. Prostrate, s prea ding and creeping; leaves linear, stipulate, oblanceolate, almost entire or toothed above the middle; flowers 2 to 4 in cluster; fruit dark purplish-

red. Sandy and rocky shores.

P. americana, Wild Plum. Tree 3 to to m. high; leaves more or less thorny, narrowly obovate, long, acuminate, sharply serrated; flowers large; petals narrowly obovate, about $1 \mathrm{~cm}$. long; fruit becoming red at maturity, about $2 \mathrm{~cm}$. in diameter. River banks and borders of woods.

\section{RUBUS}

Perennial herbs or somewhat shrubby, with white or reddish flowers, numerous stamens, usually numerous carpels becoming small drupes collected on a spongy or fleshy receptacle.

R. idaeus aculeatissimus, RED RASPBERRY. Prickly stemmed, upright shrubs, and beset with straight stiff bristles; leaflets 3 to 5 , 
oblong-ovate, cut-serrate; petals white, as long as the bristly-hispid calyx; fruit light red, falling off whole from the dry receptacle. Thickets. May to July.

R. occidentalis, BLACK RASPBERRY. Glaucous shrubs, with stems recurved and armed with hooked prickles, not bristly; leaflets mostly 3, ovate, coarsely double-serrate; petals white, shorter than the sepals; fruit purple-black, falling off whole from the dry receptacle. Thickets and fence rows. May, June.

R. odoratus, Purple Flowering Raspberry. Unarmed shrubs, the branches, stalks, and calyx bristly with glandular hairs; leaves simple, 3 to 5 lobed, the middle lobe prolonged; flowers large and showy; petals rounded, purple rose-color; fruit large and red, separating from the receptacle as in all raspberries. Rocky woods. June to August.

R. triflorus, DWARF RASPBERRY. LOw and herbaceous, ascending or trailing, unarmed; leaves with 3 or 5 leaflets, which are rhombicovate or ovate-lanceolate, acute at both ends, thin and smooth; petals small, erect, white or pink; fruit red, not separating easily from receptacle. Damp woods. May to July.

\section{R. allegheniensis, TALL} BlackBerRy. Armed shrubs, reaching $2 \mathrm{~m}$. in height, the old stems purplish and with stout prickles; leaves palmately compound with 3 or 5 leaflets, which are villous above and velvety beneath; branchlets, pedicels, etc.,

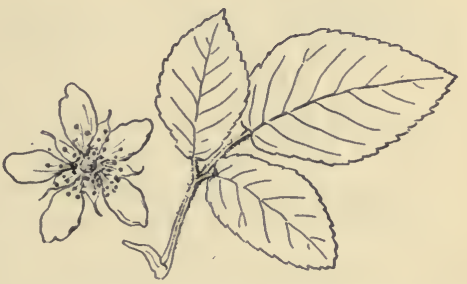

Rubus allegheniensis, Tall blackberry. glandular-pubescent; fruit subcyclindric, blackish, not separating from the fleshy receptacle. Open thickets and clearings. May to July.

R. hispidus, Swamp Blackberry. Prostrate or nearly so, the slender stem beset with retrorse prickles; leaflets thickish, dark green or shining above; racemes few-flowered; fruit small, reddish-purple. Moist woods and swampy meadows.

R. villosus, Dewberry. Becoming prostrate, the rather woody stem armed with stout retrorse prickles; fruiting branches upright; leaflets thin, doubly serrate, flowers in leafy racemes; fruit blackish, with few to many large drupelets. Dry, open places.

SPRING FLORA-6 


\section{LEGUMinOSEAE (Pulse Family)}

Herbs, shrubs, and trees with alternate, usually compound leaves. Flowers usually irregular, with Io stamens and a single pistil becoming a pod in fruit. The irregular corolla is said to be papilionaccous, that is, with the upper petal larger than the others, and enclosing them in a bud, usually turned backward. The two lateral ones exterior to the two lower ones, which are more or less coherent, forming a keel enclosing the stamens and pistil.

\section{GLEDITSIA}

Thorny trees with once or twice pinnate leaves, and inconspicuous greenish regular flowers in small spikes. 3 to ro dis-

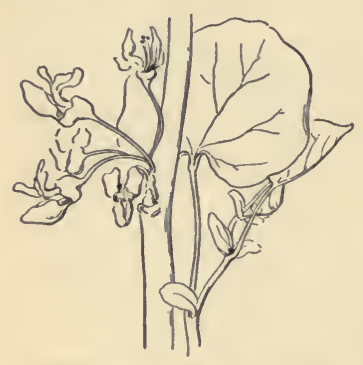

Cercis canadensis, Redbud. tinct stamens, and a flat many-celled pod.

G. triacanthos, HoNEY LoCUST. Thorns stout, often 3-pronged; leaflets lanceolate-oblong; pods linear, elongated ( 2 to $5 \mathrm{dm}$. long), often twisted, filled with sweet pulp between the seeds. Rich woods. May, June.

\section{CERCIS}

Trees with heart-shaped, simple leaves, reddish-purple, almost regular flowers in umbels, appearing before the leaves. Io distinct stamens, and an oblong, flat, many-seeded pod.

\section{C. canadensis, REDBUd. A small tree} with pointed leaves and pods nearly sessile. Rich soil.

\section{LUPINUS}

Herbs with palmately-compound leaves and showy blue flowers in terminal racemes. Stamens monadelphous. A scythe-shaped, oblong keel. Pods flat.

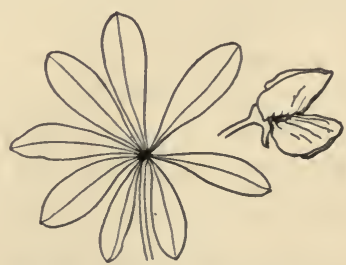

Lupinus perennis, Lupine.

L. perennis, Lupine. Somewhat hairy, stem erect, 3 to $6 \mathrm{dm}$. high ; 
leaflets 7 to II, oblanceolate; flowers in a long raceme, purplish-blue; pods broad, very hairy with 5 or 6 seeds. Sandy soil. May, June.

\section{TRIFOLIUM}

Tufted shrubs with mostly palmately, 3-foliolate leaves. Flowers in heads or spikes. Keel short and obtuse and the Ioth stamen more or less separate from the others. Pods small, often included in calyx.

T. pratense, RED CLOVER. Stems ascending, somewhat hairy; leaflets oval or obovate, often notched at end and marked on upper side by pale spots; stipules broad, bristly-pointed; flowers sessile in dense ovoid heads; corolla magenta to whitish. Fields and mead-
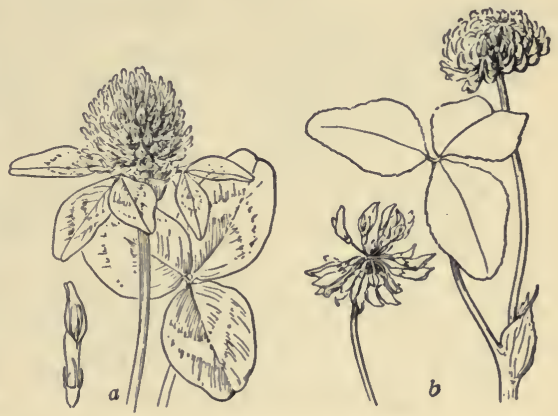

Trifolium; $a, T$. pratense, Red clover; $b, T$. repens, White clover. ows.

T. repens, White Clover. Stem smooth, slender, spreading and creeping; leaves inversely heart-shaped; stipules scale-like, narrow; petioles and peduncles very long; flowers stalked in short heads; calyx

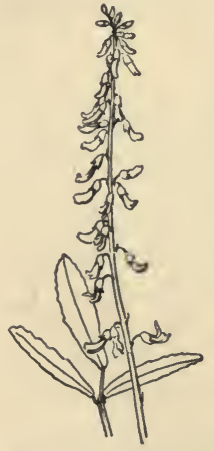

Melilotus officinalis, Yellow melilot. much shorter than the white corolla. Fields and roadsides.

T. hybridum, Alsike Clover. Like the last, but stems erect or ascending; leaflets ovate, rounded at apex; flowers rose-tinted.

\section{MELILOTUS}

Herbs, fragrant in drying, with pinnately 3 foliolate leaves. Flowers, as in trifolium, but in spike-like racemes. Pod ovoid, wrinkled and longer than the calyx.

M. officinalis, YelLow MeLiLot. Upright, usually tall; leaflets obtuse, closely serrate; petals yellow, of nearly equal length; pod prominently crossribbed. Waste ground. 
M. alba, Sweet Clover. Tall; leaflets serrate, truncate; petals white, the standard longer than the other petals; pods somewhat reticulate. Rich soils and along roadsides.

\section{MEDICAGO}

Herbs with pinnately 3 -foliolate leaves, toothed leaflets, and flowers as in Melilotus. Pod curved or coiled.

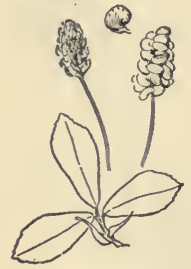

Medicago lupulina, B la c k medick.

M. lupulina, Black Medick. Procumbent and pubescent; leaflets wedge-obovate, toothed at apex; flowers yellow, in short spikes; pods kidney-formed. Waste places.

\section{ROBINIA}

Trees or shrubs, often with spines replacing stipules. Pinnate leaves and showy flowers in drooping racemes. Diadelphous stamens and linear flat pods.

R. pseudacacia, Сомmon Locust. A valuable timber tree; branches smooth; flowers white, fragrant, in slender loose racemes; pods smooth.

- Common in cultivation. May, June.

\section{VICIA}

Herbs mostly climbing by a tendril at the end of the pinnate leaves. Half-sagittate stipules. Axillary flowers. Style hairy all round or only on the back at the apex. Pods flat.

V. caroliniana, Vетсн. Nearly smooth; leaflets 8 to 24 , oblong, obtuse; peduncles loosely-flowered; flowers small, whitish; keel topped with blue. River banks. April to June.

V. americana, "VETCH. Leaflets glabrous, ro to I4, elliptical, ovate-

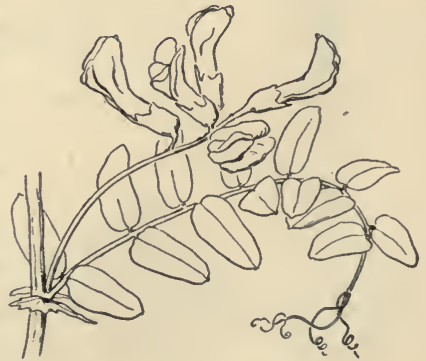

Vicia americana, Vetch. oblong, very obtuse; peduncles 4 to 8 flowered; flowers purplish. Moist soil. May, June. 


\section{LATHYRUS}

Closely resembling Vicia, but style dilated and flattish, hairy only on the inner side.

L. palustris, Marsh PEA. Slender and glabrous; stems usually winged; stipules lanceolate, ovate, sharp-pointed at both ends; leaflets 3 or 4 pairs, lanceolate to elliptic; peduncles 3 to 5 flowered; flowers purple. Banks of rivers and lakes. June to August.

L. venosus, Wild PeA. Stout, climbing, ' usually somewhat hairy; stipules very small and slender; leaflets 4 to 6 pairs, oblong, ovate; peduncles many-flowered; flowers purple. Shaded banks. May to July.

L. ochroleucus, Wild PEA. Stems slender, 3 to $9 \mathrm{dm}$. high; stipules semi-cordate, half as large as the ovate leaflets; pe-

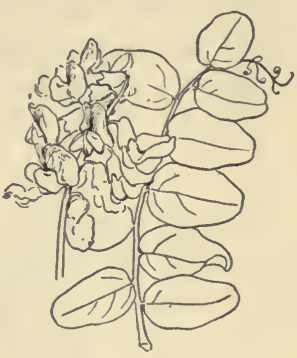

Lathyrus venosus, Wild pea. duncles 7 to Io flowered; flowers yellowish-white. Hillsides. May to July.

\section{OXALIDACEAE (Wood Sorrel Family)}

Low herbs with sour, watery juice. Leaves palmate, with 3 obcordate leaflets. Flowers with Io to I5 stamens and a superior 5 -celled ovary.

\section{OXALIS}

Sepals 5 , persistent; petals 5 ; stamens Io, usually united at base. Styles 5 and distinct. Pod cylindric.

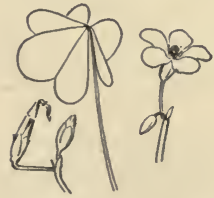

Oralis stricta, Yellow wood sorrel.

O. violacea, Violet Wood Sorrel. Stemless, nearly glabrous; base bulbous and scaly; leaves radical; stem naked, bearing an umbel of several violet flowers. Rocky places and open woods.

O. stricta, Yellow Wood Sorrel. Pale green, pubescent or strigose; stems several, decumbent, stoutish; pedicels at length deflexed, mostly 2; petals pale yellow, often with a reddish spot near the base. Dry or sandy soil.

O. corniculata, Yellow Wood Sorrel. Coalescent, regular or de- 
cumbent; pedicels clustered at the summit of the peduncle, ascending with spreading hairs; petals yellow. Dry or moist soil.

\section{GERANIACEAE (Geranium Family)}

Herbs with lobed or divided leaves and regular floz'ers, and five glands alternating with the petals. Stamens as many, or twice as many as the sepals and ovary deeply lobed.

\section{GERANIUM}

Plants with forking stems. Peduncles $I$ to 3 flowered. Io stamens with perfect anthers, the five longer ones with glands at their base, and the two carpels separating with their long styles, when mature, from the elongated axis.

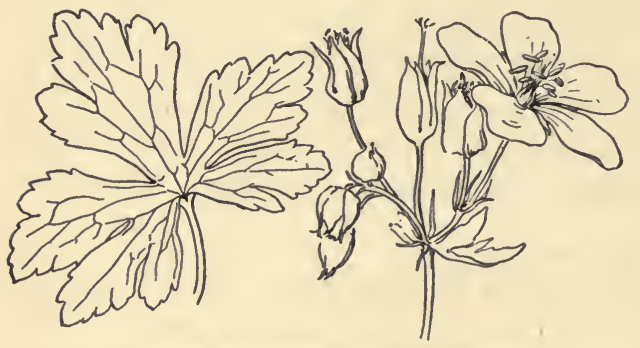

Geranium maculatum, Wild geranium.

G. m a cul atum, WiLd GERA NI U M. Erect and hairy; leaves 5-parted, the wedge-shaped divisions lobed and cut at the end; sepals slender, pointed; pedicels and beak of fruit hairy; petals entire, light purple, bearded on the claw, more than I cm. long. Fields and open woods. April to July.

G. carolinianum, Wild Geranium. Diffusely branched, hairy; leaves cut and cleft into many oblong-linear segments; flowers in a close cluster; sepals about as long as the whitish or very pale pink petals; beak of fruit tipped with a short style. Rocky places. May, June.

\section{RUTACEAE (RUe FAMily)}

- Shrubs or trees, usually arith alternate, compound leaves. Flozer with 3 to 5 parts and stamens as many, or twice as many as the sepals. 


\section{ZANTHOXYLUM}

Shrubs or trees with pinnate leaves, small greenish flowers and thickened fleshy pods.

Z. americanum, Prickly Ash. An aromatic shrub; leaflets 2 to 4 pairs, downy when young; flowers yellowish-green, appearing before the leaves in sessile, umbellate clusters; calyx none; petals 4, 5 ; pistils 3 to 5 , forming fleshy pods. Rocky woods and river banks. April, May.

\section{PTELEA}

Shrubs with trifoliolate leaves and greenishwhite, small flowers in terminal flat-shaped clusters. 3 to 5 sepals and the same number of petals. Fruit nearly orbicular, winged all round (a

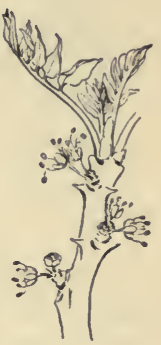

Zanthoxylum americanum, Prickly ash. samara).

P. trifoliata, Hop Tree. A tall shrub, with ovate, pointed leaflets, downy when young. The bitter fruit is used as a substitute for hops. Rocky places. June.

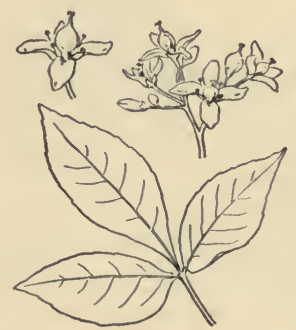

Ptelea trifoliata, Hop tree.

\section{POLYGALACEAE (Milkwort FAMiLy)}

Herbs with simple, entire leaves, very irregular flowers, and diadelphous or monadelphous stamens. Anthers opening at the top, and fruit a 2 -seeded pod.

\section{POLYGALA}

Calyx of 5 sepals, 3 of which are small and the other 2 much larger, and colored like the petals. Petals 3 , connected with each other and with the stamen-tube, the middle one keel-shaped. Stamens 6 or 8 , their filaments united into a split sheath or into 2 sets.

P. Senega, Seneca Snakeroot. Stems from thick, knotty rootstocks, simple, reaching $3 \mathrm{dm}$. in height; leaves lanceolate, with rough 


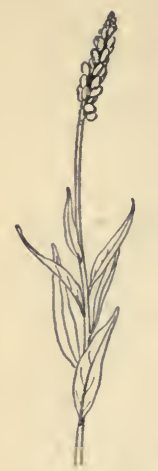

margins; flowers white, in a single close spike. Rocky soil. May to July.

\section{EUPHORBIACEAE (SPURge Family)}

Herbs with milky juice, mostly apetalous flowers and 3-celled ovary. The fruit a 3-lobed capsule.

\section{EUPHORBIA}

Polygala Senega, Seneca snakeroot.

Herbs with peduncles terminal, often in umbellate clusters. Flowers monoecious, included in a cupshaped, 4 or 5 lobed involucre resembling a calyx or corolla. Staminate flowers numerous, lining the base of the involucre. Pistillate flowers solitary, in the middle of the involucre, soon protruded on a long pedicel.

E. Cyparissias, Cypress Spurge. Stems densely clustered, from running rootstocks, reaching $3 \mathrm{dm}$. in height, crowded with linear, entire leaves; floral leaves heart-shaped; umbels many-rayed; glands crescent-shaped. Escaped from gardens.

\section{LIMNANTHACEAE (False MERMaid Family)}

Low herbs with alternate, pinnate leaves, perfect, regular flowers with 3 to 6 parts. Glands alternate with the petals. Carpels nearly distinct, but with a common style, becoming fleshy and separating from the short axis.

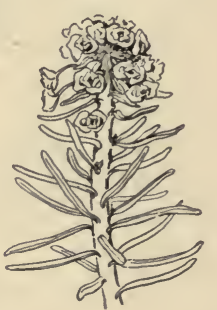

Euphorbia Cyparissias, Cy press spurge.

\section{FLOERKEA}

Small shrubs with minute, solitary flowers on axillary peduncles. Sepals 3. Petals 3, shorter than the calyx. Stamens 6. Ovaries 3 , united only at base. Fruit composed of 3 roughish achenes.

F. proserpinacoides, False Mermaid. Leaflets 3 to 5 , lanceolate, sometimes 2 to 3 cleft. Marshes and river banks. April to June. 


\section{ANACARDIACEAE (CASHEW FAMILY)}

Trees or shrubs with alternate leaves, and small regular flowers in spikes or heads. A I-celled ovary with 3 styles or stigmas. Fruit drupe-like.

\section{RHUS}

Leaves usually compound. Flowers greenishwhite or yellowish. Sepals and petals 5. Stamens 5 .

R. canadensis, Fragrant Sumac. A straggling

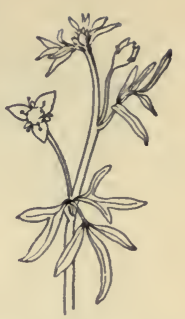

Floerkea proser. pinacoides, False mermaid. bush, I to $2 \mathrm{~m}$. high; leaves with 3 leaflets which are rhombic-obovate, or ovate, cut-toothed; flowers pale yellow, in small spikes or heads, appearing in spring before the leaves; fruit clothed with crimson hairs. Dry rocky banks.

\section{AQUIFOLIACEAE (Holly Family)}

Trees or shrubs with simple leaves, small white or greenish flowers, with parts 4 to 8. Fruit a drupe.

\section{ILEX}

Trees or shrubs with alternate leaves. Calyx 4 to 6 toothed. Petals and stamens 4 to 6 . The berry-like drupe containing 4 to 6 nutlets.

I. verticillata, WinterberRy. Shrubs with deciduous leaves, oval, obovate or wedge-lanceolate, serrate, downy on the veins beneath; flowers very short-peduncled; calyx lobes ciliate on the margins; fruit red. Low grounds. May, June.

\section{NEMOPANTHUS}

A branching shrub with gray bark. Alternate, deciduous, entire or slightly toothed leaves. Flowers on long axillary peduncles, solitary or somewhat clustered. Parts of the flower 4 or 5 .

N. mucronata, Mountain Holly. Erect, reaching $3 \mathrm{~m}$. in height; leaves elliptic-oblong, thin; drupe light-red. Damp woods. 


\section{Celastraceae (Staff Tree Family)}

Shrubs with simple leaves and small regular flowers. 4 or 5 stamens, as many as the petals, and inserted on a disk which fills the bottom of the calyx. Fruit 2 to 5 -celled.

\section{EUONYMUS}

Shrubs with 4-sided branches. Opposite serrate leaves. Loose cymes of small perfect flowers on axillary peduncles. Parts of the flower 4 or 5 , about 3 to 5 -lobed.

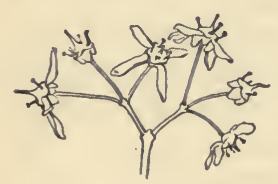

Euonymus atropurpureus, Waahoo.

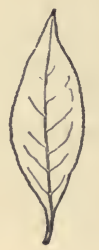
Seeds enclosed in an aril.

E. atropurpureus, WAAHoo. Treelike shrub reaching $4 \mathrm{~m}$. in height; leaves petioled, oval-oblong; flowers dark purple; pods smooth, deeply lobed.

\section{CELASTRUS}

Twining shrubs with alternate leaves and small greenish flowers in raceme-like clusters. Petals and stamens 5. Pod globose, orange-colored, 3-celled. Seeds enclosed in a pulpy scarlet aril.

C. scandens, Bittersweet. Leaves ovate-oblong, finely serrate, pointed; the opening orange-colored pods display the scarlet covering of the seeds. Along streams and in thickets. June.

\section{STAPHYLEACEAE (BladdeR-NUT FAMili)}

Shrubs or small trees with opposite pinnate leaves, perfect flowers, and stamens as many as the petals, and borne outside a large disk.

\section{STAPHYLEA}

Upright shrubs with pinnate leaves; leaflets 3 or 5 , serrate; flowers white, in drooping racemes; sepals and petals 5; pistil of 3 carpels; fruit a large, inflated 3 -celled pod, bursting at the summit. 
S. trifolia, Bladder Nut. Shrub $3 \mathrm{~m}$. high; branches greenish, striped; leaflets 3, ovate, pointed. Moist thickets. May.

\section{ACERACEaE (Maple Family)}

Trees and shrubs with opposite, simple, usually palmately lobed leaves. Sinall apetalous flowers and a 2-celled, 2-lobed ovary.

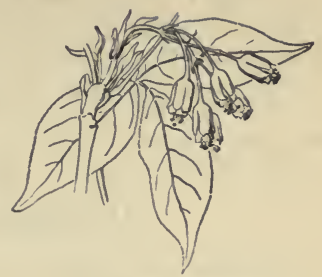

Staphylea trifolia, Bladder nut.

\section{ACER}

Calyx colored, mostly 5-lobed. Petals either none, or as many as the sepals. Stamens 3 to 12. Ovary 2-celled. The back of each carpel develops a wing, converting the fruit into 2 I-seeded samaras, or key-fruits.

A. saccharum, Sugar Maple. A large tree; leaves 3 to 5-lobed with pointed sinuate-toothed lobes; flowers in nearly sessile, flattopped clusters, greenish-yellow, appearing with the leaves, drooping on slender, hairy pedicels; petals none; wings of fruit broad. Rich woods. April, May.

A. saccharinum, Silver Maple. A handsome tree; leaves very deeply 5-lobed, with the sinuses rather acute, silvery-white beneath, the divisions narrow, cut-lobed and toothed; flowers in umbels, much preceding the leaves; petals none; fruit woolly when young. River

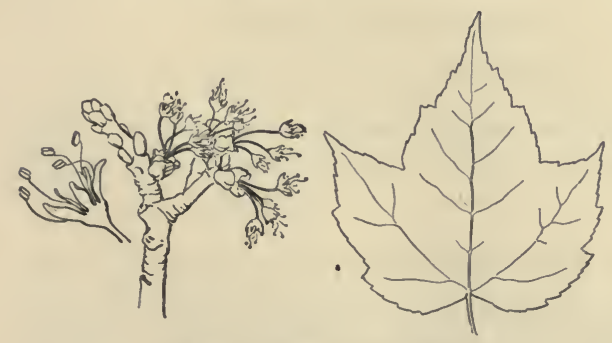

Acer rubrum, Red maple. banks. March, April. A. rubrum, RED MAPLE. A mediumsized tree with reddish twigs; leaves exceedingly variable in shape and broadly ovate or suborbicular, truncate or cordate at base, woolly when young, whitened beneath; the acuminate lobes irregularly serrate; petals linear-oblong; fruit smooth on long drooping pedicels. Wet woods. April. 
A. Negundo, Box Elder. A low tree with light green twigs; leaves pinnate with 3 to 9 veiny, ovate, pointed, toothed leaflets; flowers greenish, in drooping clusters, earlier than the leaves; petals none; fruit smooth. River banks. April.

\section{SAPINDACEAE (SOAPBERRy FAMily)}

Trees or shrubs with alternate or opposite compound leaves. Flowers unsymmetrical. Stamens more numerous than the sepals.

\section{AESCULUS}

Leaves opposite, palmately compound. Leaflets serrate and straight-veined. Flowers in a terminal close cluster. Petals 4 or 5 , more or less unequal. Stamens 6 to 8 . Ovary 3-celled. Style I. Fruit a leathery, 3-celled and 3-seeded pod.

A. glabra, Buckeye. A large tree; leaflets usually 5; stamens curved, longer than the corolla; petals 4 , upright; fruit covered with prickles when young. River banks. June.

\section{VITACEAE (Vine Family)}

Shrubs usually climbing by tendrils, with alternate, palmate leaves. Tendrils and flower clusters opposite the leaves. Stamens as many as the petals, and opposite them. Berry 2-celled, usually 4-seeded.

\section{VITIS}

Climbing by the coiling and naked tendrils. Flowers in a large cluster, fragrant. Simple leaves, rounded and heart-shaped. Berry pulpy.

V. labrusca, Northern Fox Grape. Branchlets and young leaves very woolly; leaves entire or deeply lobed, dentate, continuing rustywoolly beneath; berries large, dark purple or amber color. In cultivation this group has given rise to the concord, catawba, and other varieties. Thickets.

V. aestivalis, Summer Grape. Branchlets pubescent; leaves un- 
lobed or more or less deeply, 3 to 5-lobed, with broad teeth, very woolly when young, tawny-flocculent, even in age; berries middlesized, black. Thickets. May, June.

V. cordifolia, Frost Grape. Leaves smooth and mostly shining, unlebed or slightly 3 -lobed, deeply cordate, sharply toothed; stipules small; berries black and shining, very sour. Thickets and stream banks. May, June.

V. vulpina, River Grape. Resembling the last, but leaves more shining and usually 3-lobed; stipules larger and more persistent; berries blue with a bloom. Stream banks.

\section{TIIIACEAE (Linden FAMILy)}

Trees with soft white wood. Leaves alternate, heart-shaped, serrate. Small cymes of cream-colored, fragrant floicers, hanging on the axillary peduncles. Fruit globular, dry and woody.

\section{TILIA}

Sepals and petals 5. Stamens numerous. Filaments cohering in 5 clusters. Pistil with a 5 -celled ovary.

T. americana, BAsSwood. Leaves large, green, and glabrous; floral bract, which is united to the axillary peduncle, tapering or stalked at base; fruit obscurely ribbed. Rich woods. May, June.

\section{MalvaCEaE (Mallow Family)}

Herbs or shrubs with alternate, palmately veined leaves. Flowers regular, with numerous stamens, monadelphous, in a column, and several carpels with ovaries united in a ring, or forming a several-celled pod.

\section{MALVA}

Herbs with 3 -leaved involucel like an outer calyx. Petals obcordate. Fruit depressed, separating at maturity into as many kidney-shaped carpels as there are styles.

M. rotundifolia, Common Mallow. Stems procumbent; leaves long, 


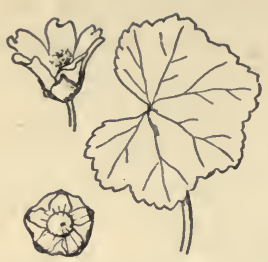

Malva rotundifolia, Common mallow.

round-shaped, on very long petioles, obscurelylobed and crenate; flowers clustered in the axils; petals whitish, twice as long as the calyx; carpels pubescent. Roadsides and cultivated grounds.

\section{CISTACEAE (Rockrose Family)}

Low shrubs or herbs with simple, mostly cntire leaves and regular flowers. Stamens numerous and distinct. Capsules I-celled.

\section{HELIANTHEMUM}

Shrubby plants with petals fugacious (or none). Stamens numerous in the petal-bearing flowers. Stigma nearly sessile. The earlier flowers with large yellow petals and indefinitely numerous petals. The later flowers much smaller, with small petals or none, and 3 to Io stamens.

H. canadense, Frostweed. Hoary, pubescent, reaching $5 \mathrm{dm}$. in height; leaves lance-oblong, pale beneath; the large flowers solitary, the small flowers clustered on short branchlets. Sandy or gravelly soil. June to August.

\section{HUDSONIA}

Small bushy shrubs covered with scale-like, persistent, downy leaves. Numerous small, showy, yellow flowers, crowded along the upper part of the branches. Style long and slender.

H. tomentosa. Heath-like plant, hoary with down; leaves oval or oblong, close pressed and imbricated; flowers sessile, or nearly so. Sandy shores. May, June.

\section{VIOLACEAE (Violet Family)}

Herbs, with alternate, stipulate leaves, axillary, nodding flowers, an irregular corolla of 5 petals (one of them spurred or saccate), 5 stamens connivent over the pistil, and a I-celled, 3-valved pod. 


\section{VIOLA}

Sepals auricled. Lower petal spurred. Stamens distinct, the 2 lower bearing spurs which project into the spur of the corolla.

V. pedata, Bird-Foot Violet. Nearly glabrous; leaves and scapes directly from a short rootstock; leaves 3 -divided, the lateral divisions 3-5 parted, the segments all linear or narrowly spatulate; upper petals dark violet, the others pale to deep lilac-purple, all beardless; style club-shaped, beakless. Open, sandy ground.

V. cucullata, Common Blue Violet. Glabrous, leaves and scapes from a thickened rootstock; leaves heart-shaped, crenate-serrate; petals violet-blue, the lateral ones bearded; style capitate, beaked on the lower side. Damp ground.

V. palmata, Palmately-leaved Violet. More or less pubescent; leaves and scapes from a thickened rootstock; leaves palmately 5-9 lobed, the segments variously toothed and cleft; petals violet-purple, lateral ones bearded; style capitate, beaked on the lower side. Rich woods.

V. sagittata, ARrow-Leaved Violet. Usually glabrous; leaves and scapes from a thickened rootstock; leaves lanceolate, long-petioled, with sagittate lobes or teeth at base; petals violet-purple, lateral ones bearded; style capitate, beaked on the lower side. Moist banks and fields.

V. lanceolata, LANCE-LEAved Violet. Glabrous; leaves and scapes from a long and filiform rootstock producing leafy runners; leaves lanceolate or linear-lanceolate; petals white, with purple lines on the 3 lower, the lateral ones usually beardless; style capitate, beaked on the lower side. Open, wet ground.

V. blanda, SweEt White Violet. Glabrous except upper surface of leaves; leaves and scapes from a long and filiform rootstock; leaves heart-shaped, minutely hairy above; petals white, with purple lines on the 3 lower, the lateral ones beardless; style capitate, beaked on the lower side. Rich woods.

V. pubescens, Yellow Violet. Pubescent plants with erect, leafy stems; leaves near the summit, broadly ovate with cordate or truncate base, crenate-dentate; petals yellow with purple veins, lateral ones bearded; style capitate, beakless, bearded at the summit. Rich woods.

V. canadensis, CANADA Violet. Minutely pubescent, glabrate plants with erect leafy stems; leaves heart-shaped, pointed, serrate; petals 


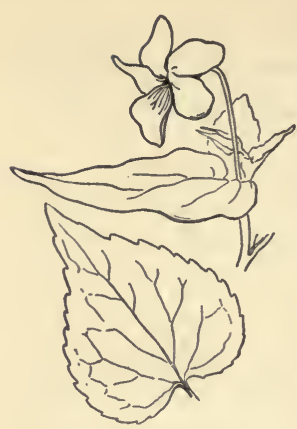

Viola canadensis, Canada violet.

white inside, outside tinged with violet, lateral ones bearded; style capitate, beakless, bearded at the summit. Woods.

V. conspersa, Glabrous or nearly so, with ascending leafy stems; lower leaves round-reniform, upper round-cordate, crenate; petals pale violet, sometimes white; style not capitate. Shaded ground.

\section{THYMELAEACEAE \\ (Mezereum Family)}

Shrubs with very tough bark. Leaves entire. Apetalous flowers with a colored calyx, bearing twice as many stamens as its lobes, and fruit a berry-like drupe.

\section{DIRCA}

A much branched shrub with jointed branches and obovate, alternate leaves. Flowers preceding the leaves. Yellow, petallike sepals. The 8 stamens and style exserted. Drupe ovoid, reddish.

D. palustris, Leatherwood. Shrub becoming $2 \mathrm{~m}$. high; wood white and brittle, but the bark remarkably tough; flowers 3 or 4 in a cluster from a bud of as many dark hairy scales. Rich woods. April.

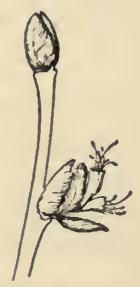

Dirca palustris Leatherwood.

ELAEAgNaceae (Oleaster Family)

Shrubs or trees with silvery-scurfy leaves, and the calyx tube becoming pulpy and berry-like in fruit, closely enclosing the achene.

\section{SHEPHERDIA}

Shrubs with opposite, entire leaves and dioecious flowers. The staminate flowers with a 4-parted calyx and 8 stamens. The pistillate flowers with a 4-cleft calyx, enclosing the ovary, and becoming berry-like. 
S. canadensis. Shrub I to $2 \mathrm{~m}$. high; leaves elliptical or ovate, nearly naked, and green above, silverydowny and scurfy, with rusty scales beneath; fruit yellowish-red. Limestone rocks and banks. May.

\section{ARALIACEAE (Ginseng FAMily)}

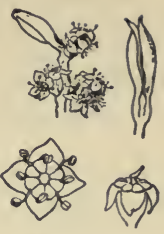

Shepherdia canadensis.

Herbs, shrubs, or trees, with compound leaves, small epigynous flowers in umbels, and fruit a drupe.

\section{ARALIA}

Herbs or shrubs, with alternate compound leaves whose ultimate divisions are pinnate, white or green flowers in umbels or panicles,

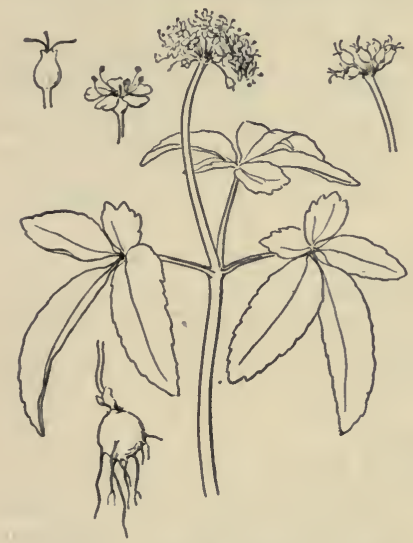

Panax trifolium, Dwarf ginseng.

5 carpels, and black fruit.

A. nudicaulis, Wild SARSAPARILla. Stem scarcely rising out of the ground, smooth, bearing a single, long-stalked leaf and a shorter naked scape with 2-7 umbels; leaflets ovate, pointed serrate. Damp woods. May, June.

\section{PANAX}

Herbs, with whorled, palmately 3-7-foliolate leaves, solitary umbels, 2 or 3 carpels, and red or yellow fruit.

P. trifolium, DWarF Ginseng. Root or tuber globular; leaflets 3-5, sessile at the summit of the leaf-stalk, narrowly-oblong; umbel simple and terminal; fruit yellowish. Rich woods. April, May.

\section{UMBELLIFERAE (PARSLEy Family)}

Herbs, with alternate, mostly compound leaves; small, epigynous, flowers in umbels; the 5 petals and stamens inserted on the disk SPRING FLORA $\rightarrow$ 
that crowns the ovary and surrounds the 2 styles; fruit of 2 seed-like and ribbed or winged carpels that separate at maturity.

\section{ERIGENIA}

Low, nearly stemless plants from deep-seated tubers. Leaves ternately decompound. Umbels of white flowers, compound, leafy-

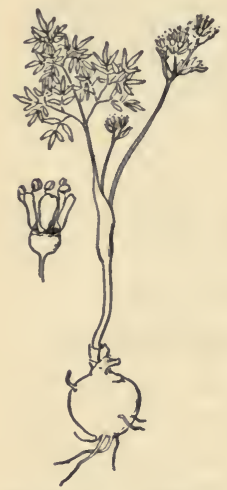

Erigenia bulbosa,

H a r binger of spring. bracted. Fruit flattened, nearly kidney-form, with very slender ribs.

E. bulbosa, Harbinger of Spring. A small, glabrous, spring plant; simple stem I or $2 \mathrm{dm}$. high; leaf segments linear-oblong; fruit $2 \mathrm{~mm}$. long, $3 \mathrm{~mm}$. broad. Woods. February to April.

\section{CHAEROPHYLLUM}

Annuals, with ternately decompound leaves, pinnatifid leaflets with oblong obtuse lobes. Umbels usually with no involucre, involucels of many bractlets, and white flowers. Fruit glabrous, narrowly oblong to linear, ribbed.

C. procumbens, Chervil. More or less hairy; stems spreading, becoming $5 \mathrm{dm}$. high; umbels with few rays; fruit narrowly oblong, contracted but not tapering at summit. Moist places. April to June.

\section{OSMORHIZA}

Glabrous or hirsute perennials with thick aromatic roots; ternately compound leaves, and ovate, dentate leaflets. Umbels of white flowers few-rayed, with few-leaved involucres and mostly bearing involucels. Fruit bristly, linear-oblong, with a prominent tail-like attenuation at base.

O. Claytoni, SweEt Cicely. Stems villous-pubescent; ternate leaves crispy-hairy, with ciliate-hispid stipules; stylopodium and style not over $\mathrm{I} \mathrm{mm}$. long. Open woods. May, June.

O. longistylis, SweEt Cicely. Usually larger, becoming I2 dm. high; stems glabrous except at the nodes; stipules densely pilose at the margin; stylopodium and style $2-4 \mathrm{~mm}$. long. Rich woods. May, June. 


\section{CRYPTOTAENIA}

Perennial, with thin 3 -foliolate leaves, no involucre, involucels of minute bractlets or none; white flowers; and linear-oblong, glabrous fruit with obtuse ribs.

C. canadensis, Honewort. Plant becoming $9 \mathrm{dm}$. high; leaflets large, ovate, pointed, doubly serrate, often lobed; umbels irregular and unequally few-rayed; fruit often curved. Woods. June, July.

\section{ZIZIA}

Smooth perennials, with ternate leaves, no involucre, involucels of small bractlets, yellow flowers, and ovate to oblong, glabrous fruit with filiform ribs.

Z. aurea, Golden Alexanders. Leaves 2 or 3ternate, the radical very long-petioled; leaflets ovate to lanceolate, serrate, acuminate; rays $\mathrm{I}^{-}$ 25; fruit oblong. Woods and meadows. April to June.

\section{TAENIDIA}

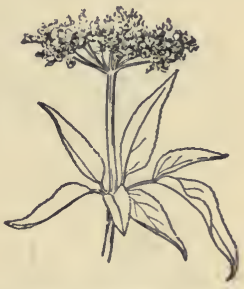

Glabrous and glaucous perennial, with ter- Zizia aurea, Golden nate leaves, mostly no involucre or involucel, Alexanders. yellow flowers, and oblong fruit with filiform ribs.

T. integerrima, Yellow Pimpernel. Slender, becoming io dm. high; leaves 2 or 3 ternate; leaflets lanceolate to ovate, entire. Sandy woods and thickets. May, June.

\section{HERACLEUM}

Tall, stout perennials, with large compound leaves, broad umbels, deciduous involucre, many-leaved involucels, white or purplish flowers, and obovate fruit, with broad lateral wings and filiform dorsal ribs.

H. lanatum, Cow PARSNiP. Woolly, with grooved stems becoming $3 \mathrm{~m}$. high; leaves ternate, with broad, irregularly cut-toothed leaflets. Wet ground. June, July. 


\section{CORNACEAE (Dogwood FAMILY)}

Usually shrubs or trees, with opposite or alternate simple leaves, epigynous flowers, stamens as many as the petals, style I, and fruit a I or 2-seeded drupe.

\section{CORNUS}

Leaves opposite, except in the last species, and entire. Flowers small, perfect, 4-merous, in naked cymes or in close heads surrounded by a corolla-like involucre. Drupe small, with a 2-celled and 2-seeded stone.

C. canadensis, Bunchberry. Stems low and simple, from a slender rootstock; lower leaves scale-like, upper ones crowded into an apparent

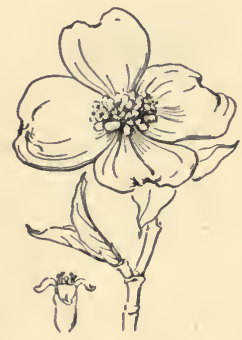

Cornus florida, Flowering dogwood. whorl, ovate and pointed; flowers greenishwhite (or petals purple-tipped), in a close cluster surrounded by an involucre of white or pinkish, ovate, shoft-acuminate bracts. Cool woods. June, July.

C. florida, Flowering Dogwood. A tree becoming $12 \mathrm{~m}$. high; leaves ovate and pointed, bracts of the involucre white or pinkish, obcordate, 3-6 cm. long. Dry woods. May, June.

C. stolonifera, RED-OSIER Dogwood. Branches bright red-purple, smooth;. leaves ovate, rounded at base, abruptly short-pointed, minutely pubescent both sides, whitish beneath; naked cymes small and flat; fruit white or lead-color. Wet ground. June, July.

C. paniculata, PANIClED Dogwood. Shrub becoming $2.5 \mathrm{~m}$. high; branches smooth, gray; leaves ovate-lanceolate, acute at base, taper-pointed, whitish beneath but not downy; naked cymes convex, loose; fruit white, on bright red pedicels. Thickets and

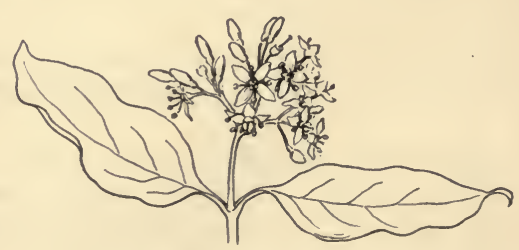

Cornus paniculata, Panicled dogwood. shores. June, July.

C. alternifolia, Alternate-Leaved Dogwood. Shrub or tree 2-6 m. high, with greenish branches streaked with white; the alternate leaves 
clustered at the ends, ovate or oval, acute at base, long-pointed; cymes broad and open; fruit deep blue. Thickets. May, June.

\section{NYSSA}

Trees, with alternate, entire, or angulate-toothed leaves, greenish dioecious, 5-merous flowers on axillary peduncles, very small petals (deciduous), 5-IO stamens, and fruit a drupe.

N. sylvatica, Sour Gum. Medium-sized tree; leaves oval or obovate, more or less pubescent when young, shining above when old; pistillate flowers 3-8 at summit of slender peduncle; fruit ovoid, bluish-black. Rich soil. April, May.

\section{ERICACEAE (HeAth FAmily)}

Mostly shrubs, with regular flowers, stamens as many or twice as many as the petals (4 or 5), anthers appendaged or opening by terminal pores, style $\mathrm{I}$, and ovary 3-10-celled.

\section{LEDUM}

Low shrubs, with alternate entire leaves clothed with rusty wool beneath and with revolute margins. Small white flowers in terminal, umbel-like clusters. 5 obovate and spreading petals and a 5 -celled capsule.

L. groenlandicum, LABRAdOR TEA. Erect, I m. or less high; leaves oblong or linear-oblong; stamens 5-7; capsule slender, cylindric. Bogs and damp thickets. May, June.

\section{RHODODENDRON}

Shrubs or small trees, with mostly alternate entire leaves. Large showy flowers in umbel-like clusters from terminal buds. Bellshaped or funnel-form corolla; and 5-celled capsule.

R. viscosum, Swamp Honeysuckle. Branchlets bristly, as well as the margins and midrib of the oblong-obovate leaves; corolla white, clammy, the tube much longer than the lobes; the 5 stamens and style long exserted. Swamps. June, July. 
R. nudiflorum, Purple Azalea. Leaves oblanceolate to obovate, sparingly pubescent; pedicels strigose hairy; flowers appearing before or with the leaves; corolla flesh-color, pink, or purple, the tube strigose, scarcely longer than the ample lobes; the 5 stamens and style long exserted; capsule strigose. Open woods and swamps. May, June.

\section{KALMIA}

Evergreen, mostly smooth shrubs, with alternate or opposite, entire, thick leaves. Showy flowers. Bell-shaped corolla with Io pouches receiving as many anthers; and 5-celled capsule.

K. latifolia, Mountain Laurel. Leaves mostly alternate, bright green both sides, ovate-lanceolate or oblong; corymbs terminal, manyflowered, clammy-pubescent; flowers pink or white. Rocky hills. May to July.

\section{ANDROMEDA}

Evergreen shrubs, with thick leaves. Clusters of pink or white flowers. Urn-shaped to cylindrical 5-toothed corolla, Io stamens; 2-4-awned anthers; and 5-celled capsule.

A. glaúcophylla, Bog Rosemary. Low shrubs with creeping base; leaves linear to narrowly oblong, white beneath with close fine pubescence; branchlets and bud-scales glaucous; flowers on thick curved pedicels in terminal umbels; capsule depressed, turban-shaped, glaucous. Bogs and banks. May to July.

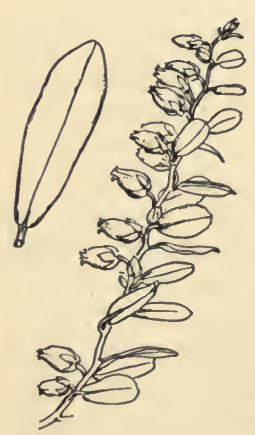

Chamaedaphne calyculata, - Leather leaf.

\section{CHAMAEDAPHNE}

Low and much branched shrubs, with nearly evergreen and thick scurfy leaves. White flowers in I-sided small racemes in the upper axils. Io stamens with anthers tapering into a tubular beak, and a depressed 5-celled capsule.

C. calyculata, LeATHER LEAF. Leaves oblong, obtuse, flat. Bogs. April, May.

\section{EPIGAEA}

Prostrate or trailing, scarcely shrubby 
plants, bristly with rusty hairs, with evergreen rounded and heart-shaped alternate leaves on slender petioles. Rose-colored flowers in axillary clusters. Corolla tube hairy within. Io stamens, and depressed-globular 5-celled capsule.

E. repens, Trailing Arbutus. Flowers appearing in early spring and exhaling a rich spicy fragrance. Rocky soil, especially in the shade of pines.

\section{ARCTOSTAPHYLOS}

Shrubs with alternate leaves. Scaly-bracted nearly white flowers in terminal racemes or clusters. Urn-shaped corolla with a 5 -toothed revolute limb. Io included stamens, anthers with 2 reflexed awns in the back near the apex. Fruit a berry.

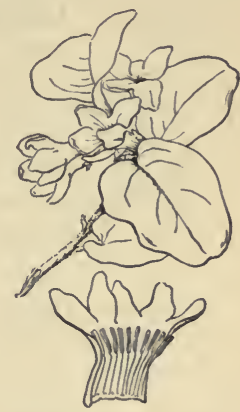

Epigea repens, Trail. ing arbutus.

A. Uva-ursi, BEARBERRY. Trailing; leaves thick and evergreen, obovate or spatulate, entire, smooth; fruit red. Rocks and bare hills. May.

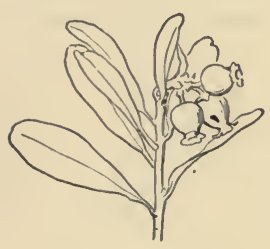

Arctostaphylos Uva-ursi, Bearberry.

\section{GAYLUSSACIA}

Branching shrubs, usually with resinous dots. Pale flowers (tinged with purple or red) in lateral racemes. Tubular or bellshaped corolla with 5-cleft border. Io stamens with awnless anthers. Ovary Io-celled and fruit a berry-like drupe.

G. baccata, HuckleberRY. Much branched, rigid, slightly pubescent when young; leaves oval to oblong, thickly clothed and at first clammy (as well as the flowers) with shining, resinous globules; racemes short, clustered, I-sided; bracts and bractlets reddish; fruit black. Rocky ground and swamps. May, June.

\section{VACCINIUM}

Shrubs with solitary, clustered, or racemed flowers; white or reddish corolla, variously shaped. 4 or 5 -cleft and revolute limb. 8 or ro stamens. Anther cells tapering into a tube. A 4 or 5 -celled berry (sometimes 8 or Io-celled by false partitions). 
V. pennsylvanicum, Low Blueberry. Low shrubs, $2-6 \mathrm{dm}$. high, the green warty stems and branches glabrous; leaves lanceolate or oblong, serrulate with bristle-pointed teeth, bright green, smooth and

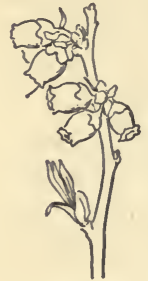

Vaccinium vacillans, Blueberry. shining both sides; corolla cylindric bell-shaped; berries usually bluish-black and glaucous. Dry ground.

V. vacillans, BlueberRy. Low, 3-9 dm. high, glabrous, with yellowish branchlets; leaves obovate or oval, very pale or dull, glaucous at least beneath, entire or minutely serrulate; calyx usually reddish; corolla urnshaped, greenish-yellow, often tinged with red; berries blue, with a bloom. Dry ground.

V. corymbosum, Swamp BlueberRy. Shrubs I-4 m. high; leaves ovate to elliptic-lanceolate, entire, smooth or somewhat pubescent beneath, half-grown at flowering time; corolla urn-shaped, white or pinkish; berries blue-black; with a bloom. Swamps and low woods.

\section{PRIMULACEAE (PRIMrose Family)}

Herbs, with simple leaves, regular flowers, stamens as many as the lobes of the sympetalous corolla, and opposite them, and a I-celled ovary with a central free placenta.

\section{LYSIMACHIA}

Leafy-stemmed perennials, with entire and dotted leaves. Corolla wheel-shaped, with entire divisions. Filaments monadelphous at base or distinct.

L. thyrsiflora, TuFted LoosestrifE. Smooth, or pubescent above when young; stem simple, becoming $8 \mathrm{dm}$. high; leaves opposite, the lowest scale-like, the others lanceolate; spike-like or head-like clusters of small, light yellow flowers in the axils of the middle leaves; corolla deeply $5-7$ parted into linear, purplish-dotted divisions; filaments distinct. Swamps. May to July.

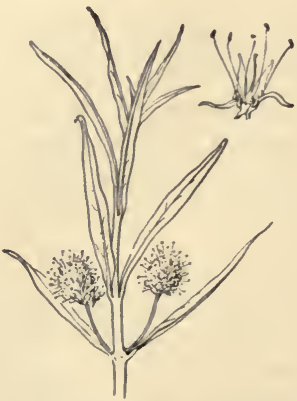

Lysimachia thyrsiflora, Tufted loosestrife, 


\section{TRIENTALIS}

Low and smooth perennials, with simple erect stems, with a few alternate, minute leaves below, and a whorl of thin veiny leaves at the summit. The slender peduncle bearing a delicate white and starshaped flower (without tube). Filaments united into a ring at base.

T. americana, Star Flower. Spreading by slender rootstocks, sometimes producing long stolons; leaves elongated-lanceolate, tapering at both ends; petals finely pointed. Woods. May to July.

\section{DODECATHEON}

Smooth herb, with a cluster of basal leaves. Simple, naked scape bearing an

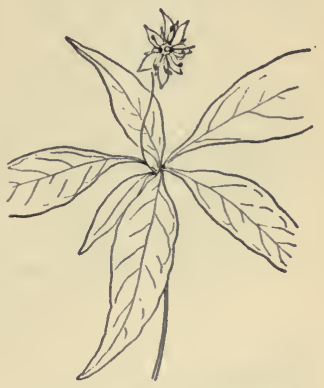

Trientalis americana, Star flower. umbel of showy flowers nodding on slender pedicels. Corolla rosecolor or white with a very short tube, and reflexed long and nar-

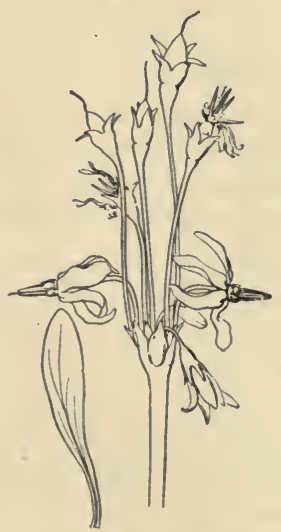

Dodecatheon Meadia, Shooting star. row divisions. Filaments short, with long, slender anthers approximate in a cone.

D. Meadia, Shooting Star. Leaves oblong or spatulate, gradually narrowed at base. Woods and moist cliffs. May, June.

\section{OLEACEAE (Olive Family)}

Trees or shrubs, with opposite and pinnate or simple leaves, a 4-parted calyx and corolla (sometimes apetalous), 2 stamens, and a 2-celled ovary.

\section{FRAXINUS}

Trees, with pinnate leaves. Flowers small, mostly apetalous, in crowded panicles or racemes. Fruit dry and winged (samara). 
F. americana, White Ash. Large and very valuable forest tree, with gray furrowed bark and smooth gray branchlets; leaflets $5-9$ petiolate, ovate or lanceolate-oblong, pointed, entire or sparingly toothed, paler beneath; fruit marginless below, abruptly dilated into a lanceolate, oblancéolate, or wedge-oblong wing. Rich woods. April, May.

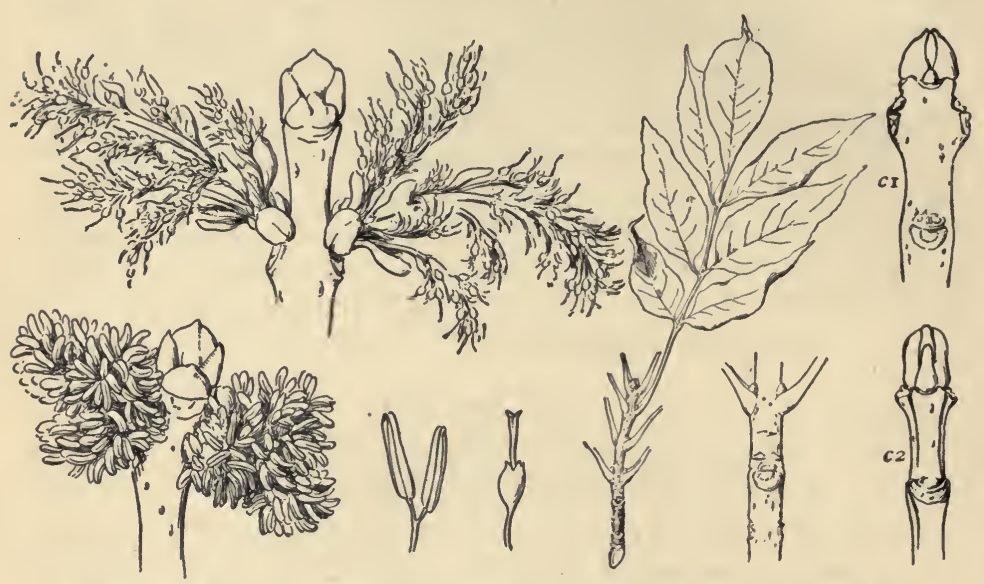

Fraxinus; $a$, and $b, F$ americana, White ash; $c$, winter bud of $F$. nigra, Black ash; $c 2$, winter bud of $F$. quadrangulata, Blue ash.

F. nigra, BlACK Ash. Small or middle-sized tree; leaflets 7-II, the lateral ones sessile, oblong-lanceolate, tapering to a point, serrate, green and smooth both sides; fruit linear-oblong or narrowly elliptical, blunt at both ends. Swamps.

\section{GENTIANACEAE (Gentian Family)}

Smooth herbs, with opposite or alternate leaves, regular flowers with stamens as many as the lobes of the corolla, a $\mathrm{I}$-cclled ovary, and fruit a capsule.

\section{MENYANTHES}

A perennial herb, with creeping rootstock sheathed by the base of the long petioles which bear 3 oval or oblong leaflets. White or 
reddish flowers in a raceme on a naked scape, and short funnelform corolla bearded inside.

M. trifoliata, Buckbean. In bogs and shallow water. April to June.

\section{POLEMONIACEAE}

\section{(Polemonium Family)}

Herbs, -with alternate or opposite leaves, regular flowers with 5 stamens, 3-lobed style, and a 3-celled ovary becoming a capsule.

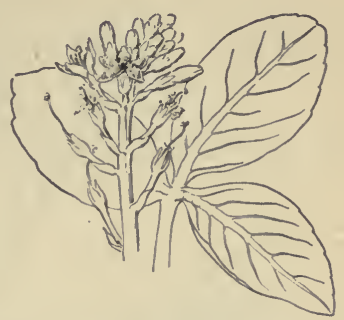

Menyanthes trifoliata, Buckbean.

\section{PHLOX}

Perennials with opposite, sessile, and entire leaves. Cymose flowers terminal or crowded in the upper axils. Salver-form corolla with a long tube that includes the very unequally inserted stamens.

P. paniculata, Panicled Phlox. Stem stout, erect, smooth or somewhat hairy above; leaves oblong-lanceolate and ovate-lanceolate, pointed, the upper often heart-shaped at base; panicle pyramidal; calyx-tube awn-pointed; corolla pink-purple varying to white. Open woods. July to September.

P. maculata, Wild SweEt William. Smooth or slightly roughish; stem slender, erect, spotted with purple; lower leaves lanceolate, upper nearly ovate-lanceolate, tapering to the apex from the broad rounded or heart-shaped base; panicle narrow, ellipsoid; calyx-teeth triangularlanceolate, short, scarcely pointed; corolla pink-purple. Rich woods and along streams. June to September.

P. pilosa, Pilose Phlox. Stems slender, nearly erect, usually hairy, as are the lanceolate or linear leaves which taper to a sharp point; cymes at length open; calyx-teeth slender, awl-shaped and awn-like; corolla pink-purple or rose-red. Dry woods. May, June.

P. divaricata, Blue Phlox. Stems spreading or ascending from a decumbent base; leaves oblong-ovate or lanceolate, acutish; cyme spreading, loosely flowered; calyx-teeth slender awl-shaped; lobes of the pale lilac or bluish corolla obcordate or wedge-obovate and notched at the end, or sometimes entire. Røcky woods. May, June. 
P. bifida, Cleft Phlox. Minutely pubescent; stems low, diffuse and branching; leaves linear, becoming nearly glabrous; flowers few

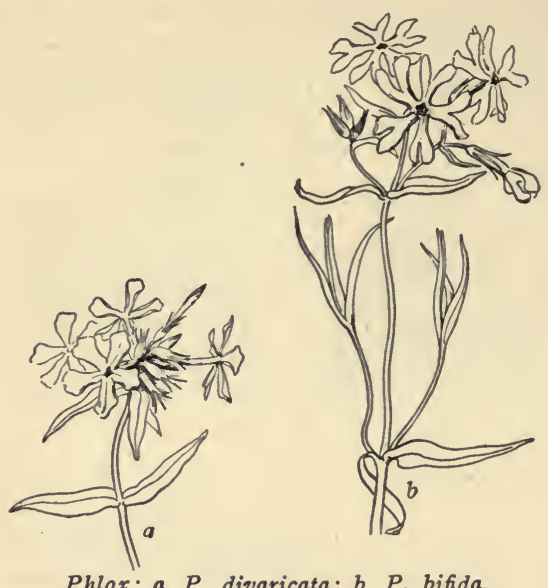

Phlox; $a, P$. divaricata; $b, P$. bifida. on slender peduncles; calyx-teeth awl-shaped; lobes of the pale-purple corolla 2-cleft to or below the middle, the divisions linear oblong. Sandy soil. May and June.

\section{POLEMONIUM}

Perennials, with alternate $\mathrm{p}$ in nat e leaves, flowers in corymbs, stamens inserted at the summit of the very short tube of the open bell-shaped corolla, and filaments hairy at base.

P. reptans, Jacos's Ladder. Smooth or slightly pubescent; stem weak and spreading; leaflets 5-I5, ovate-lanceolate or oblong; corymbs few-flowered, with nodding flowers; stamens and style included; corolla light blue; capsules about 3 -seeded. Woods. April to June.

\section{HYDROPHYLLACEAE}

(Waterleaf Family)

Herbs, usually hairy, with mostly alternate leaves, regular blue or white flowers with 5 stamens in I-sided racemes, and a I-celled entire ovary becoming a 2-valved capsule.

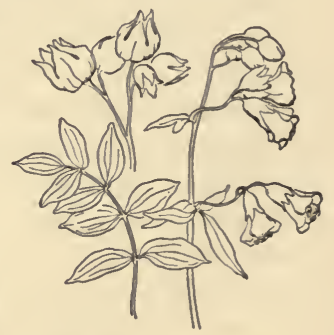

Polemonium reptans, Jacob's ladder.

\section{HYDROPHYLLUM}

Perennials, with large petioled leaves, and white or bluishpurple clustered flowers. Corolla bell-shaped, 5-cleft. Stamens and style mostly exserted, the filaments more or less bearded. 
Ovary bristly-hairy, becoming a spherical capsule containing I-4 seeds.

H. virginianum, WAterleaf. Smoothish; leaves pinnately divided, the 5-7 divisions ovate-lanceolate or oblong, pointed, cut-toothed; peduncles longer than the petioles of the upper leaves; calyx-lobes narrowly linear, bristly-ciliate. Rich woods. May to August.

H. canadense, WAterleaf. Nearly smooth; leaves palmately 5-7 lobed, rounded, heart-shaped at base; calyx-lobes linear, awl-shaped, nearly smooth. Rich woods. June to August.

H. appendiculatum, WATERLEAF. Hairy; stem-leaves palmately 5 -lobed, rounded, the lobes toothed and pointed, the lowest pinnately divided; calyx bristly-hairy, with a small reflexed lobe in each sinus. Rich woods. May, June.

\section{BORAGINACEAE (BoRAGE FAMILY)}

Mostly rough-hairy herbs, with alternate entire leaves, regular flowers with 5 stamens inserted on the tube of the corolla, solitary style, and a deeply 4 -lobed ovary forming in fruit 4 seed-like nutlets.

\section{CYNOGLOSSUM}

Coarse herbs, with petioled lower leayes. Flowers mostly in panicled racemes. Corolla funnel-form, the tube about equalling the calyx. Stamens included. Nutlets roughened all over with short barbed or hooked prickles.

C. officinale, Hound's Tongue. Strong-scented herb, clothed with short, soft hairs, leafy, panicled above; upper leaves lanceolate, closely sessile; corolla reddish-purple (nearly white); nutlets flat on the broad upper face. Waste ground.

\section{MYOSOTIS}

Low and soft-hairy herbs, with entire leaves, those of the stem sessile. Flowers small, in naked racemes. Corolla-like tube about as long as the calyx, the throat with 5 appendages opposite the lobes. Stamens included. Nutlets compressed. 
M. laxa, Forget-me-Not. Perennial from slender subterranean shoots; stems very slender, decumbent; pubescence appressed; leaves lanceolate-oblong; calyx open in front, its lobes as long as the tube; corolla pale blue. In water and wet ground. May to August.

M. virginica, FORGET-ME-NOT. Bristly-hirsute, branched from the base, erect; leaves obtuse, linear-oblong; calyx very hispid closing in fruit; corolla very small, white. Dry grounds and rocky woods. April to July.

\section{MERTENSIA}

Smooth herbs, with pale and entire leaves. Flowers purplishblue in loose clusters. Corolla longer than the calyx. Nutlets

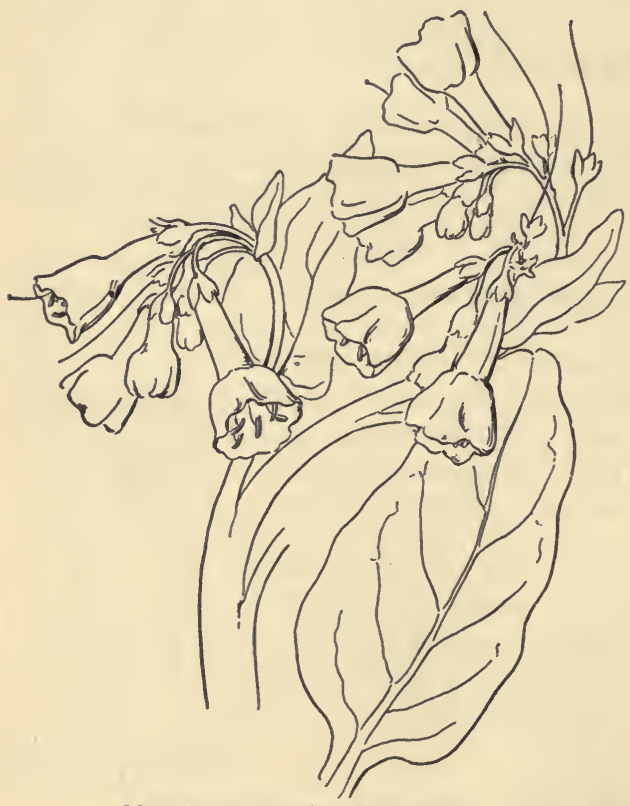

Mertensia virginica, Lungwort.

thers, and smooth or rough, hard nutlets. ovoid, fleshy when fresh.

M. virginica, LUNGwORT. Very smooth, pale, erect; leaves obovate, veiny; corolla trumpet-shaped, many times exceeding the calyx, light blue ( $\mathrm{pinkish}$ in bud), rarely white; filaments exserted; nutlets $\mathrm{rough}$ is h. Stream banks. April, May.

\section{LITHOSPERMUM}

Herbs, with thickish, and usually red roots, sessile leaves, solitary or spiked flowers, almost sessile, included an-

L. arvense, Gromwell. Minutely rough and hoary; stems erect; leaves lanceolate or linear; corolla nearly white, scarcely longer than 
the calyx; nutlets tubercled or rough-wrinkled, gray and dull. Roadsides. May to August.

L. Gmelini, Puccoon. Hispid with bristly hairs; stem leaves lanceolate or linear, those of the flowering branches ovate-oblong; flowers peduncled, crowded, showy, deep orange-yellow, woolly at base inside, the tube much exceeding the calyx; fruiting calyx 3-4 times longer than the white, smooth, and shining nutlets. Pine barrens. April to June.

\section{L. canescens, Puccoon. Softly hairy and} hoary; leaves obtuse, linear-oblong, more or less downy beneath; flowers sessile; corolla deep
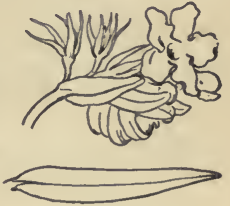

Lithospermum Gmelini, Puccoon. orange-yellow, naked at base inside, the tube much exceeding the calyx; fruiting calyx barely twice the length of the white, smooth, and shining nutlets. Dry woods. April, May.

\section{LABIATAE (Mint Family)}

Herbs, with square stems, opposite leaves, more or less 2-lipped corolla, usually didynamous stamens, and a deeply 4-lobed ovary which forms in fruit 4 little seed-like mutlets.

\section{NEPÉTA}

Perennial herbs. Calyx more or less curved. Corolla dilated in the throat; the upper lip erect and notched; the lower 3 -cleft, the

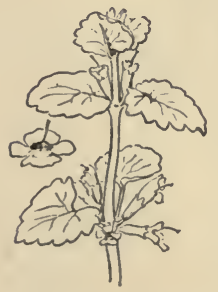

Nepeta hederacea, Ground ivy. middle lobe largest. Stamens ascending, exserted.

N. hederacea, Ground Ivy. Creeping and trailing; leaves petioled, round-kidney-shaped, crenate; corolla light blue, thrice the length of the calyx. Shady ground. May to July.

\section{LAMIUM}

Decumbent herb. Lowest leaves small and long petioled, the middle heart-shaped and doubly toothed, the uppermost ones subtending the whorled flower cluster. Corolla dilated at throat; upper lip arched; middle lobe of lower lip broad and notched. 
L. amplexicaule, Henit. Low; leaves rounded, deeply crenatetoothed or cut, the upper ones clasping; corolla small, purplish, the upper lip bearded, the lower spotted. Waste ground. April to October.

\section{SOLANACEAE (Nightshade Family)}

Herbs, with alternate leaves, regular flowers with 5 stamens,

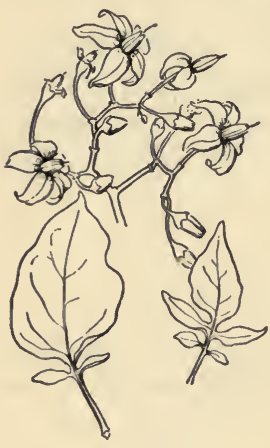

Solanum Dulcamara, Nightshade; Bittersweet. and fruit a 2-celled, many-seeded capsisle or berry.

\section{SOLANUM}

Herbs, with a 5-cleft, wheel-shaped corolla. Stamens exserted, the anthers converging around the style and opening at the tip by 2 pores. Berry usually 2 -celled.

S. Dulcamara, BitTersweet. A climbing or twining perennial, more or less pubescent; leaves ovate-heart-shaped, the upper halperdshaped, or with 2 ear-like lobes or leaflets at base; flowers small, purple or blue, in small cymes; berries ovoid, red. Moist ground. June to September.

\section{SCROPHULARIACEAE (FIGWORT FAMILY)}

Herbs, with a 2-lipped or more or less irregular corolla, usually didynamous stamens inserted on the tube, and fruit a 2-celled capsule.

\section{IINARIA}

Herbs, with at least upper leaves alternate. Corolla spurred at base on the lower side, and thin capsule opening below the summit by one or more pores or chinks.

L. vulgaris, Toadflax. Glabrous, erect; leaves pale, linear or nearly so, extremely numerous; dense

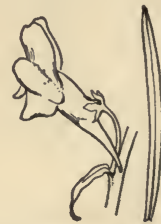

Linaria vulgaris, Toadflax. raceme of yellow flowers. Fields and roadsides.

L. canadensis. Slender, glabrous, flowering stems nearly simple; 
leaves narrow and entire; racemes of blue or purple flowers slender, loose. Sandy ground.

\section{COLLINSIA}

Slender herbs, with opposite leaves, and parti-colored flowers in umbel-like clusters, which appear whorled in the axils of the upper leaves. Corolla 2-cleft, the short tube saccate on the upper side, the middle lobe of the lower lip saccate and inclosing the declined stamens. Stamens 4 , with a gland-like rudiment of the fifth.

C. verna, Blue-eyed MARy. Lower leaves ovate, upper ovate-lanceolate, clasping by the heart-shaped base, toothed; whorls about 6flowered, flowers long-peduncled; corolla blue and white, more than twice exceeding the calyx. Moist ground. April to June.

\section{SCROPHULARIA}

Herbs, with mostly opposite leaves, and

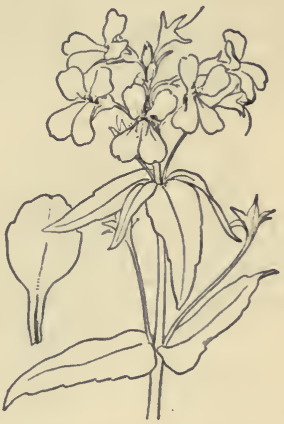

Collinsia verna, Blue-eyed Mary. small greenish-purple flowers in a loose terminal cluster. Corolla inflated, more or less globular, with 4 erect lobes and one spreading one.

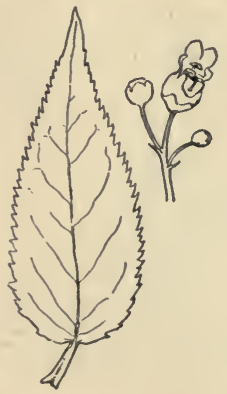

S. marilandica, Figwort. Perennial, with square stem, glandular-puberulent in the pyramidal flowercluster; leaves ovate to ovate-lanceolate, acuminate, serrate; capsule thin, subglobose, with short conical summit. Rich woods. July to September.

\section{VERONICA}

Herbs, with opposite or whorled leaves. Corolla wheel-shaped or salver-shaped, almost regular. Stamens 2, one on each side of the upper

Scrophularia marilan. dica, Figwort. lobe of the corolla. Capsule flattened, obtuse or notched at apex.

V. officinalis, SPEedwell. Pubescent; stem prostrate; leaves shortpetioled, obovate-elliptical or wedge-oblong, obtuse, serrate; racemes SPRING FLORA-8 
densely, many-flowered; corolla pale blue; capsule obovate-triangular, broadly notched. Dry woods and hillsides. May to August.

V. serpyllifolia, Thyme-leaved Speedwell. Nearly smooth, much branched at the creeping base; leaves ovate or oblong, obscurely crenate, the lowest petioled, the upper passing into lanceolate bracts; raceme loose; corolla whitish or pale blue, with deeper stripes; capsule rounded, obtusely notched. Damp meadows. May to July.

V. peregrina, Purslane Speedwell. Puberulent or nearly smooth, erect, branched; lowest leaves petioled, oval-oblong, toothed, the others

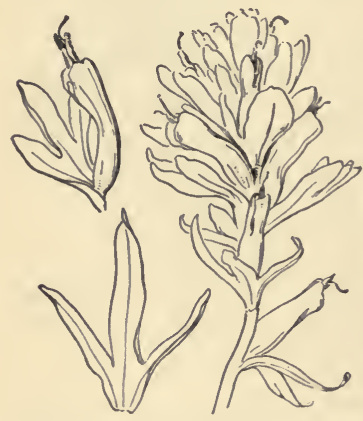

Castilleja coccinea. Painted cup. sessile; the upper oblong-linear and entire; axillary whitish flowers almost sessile; capsule orbicular, slightly notched. Waste grounds. April to October.

\section{CASTILLEJA}

Herbs, with alternate leaves, the floral ones usually dilated, colored, and more showy than the reddish or yellow spiked flowers. Calyx tubular, cleft down the lower and often also the upper side. Tube of corolla.included in calyx, its upper lip elongated and keeled.

C. coccinea, Painted Cup. Hairy; root-leaves clustered, mostly entire, obovate or oblong; those of the stem incised; floral leaves 3-5 cleft, bright scarlet toward the summit; calyx equally cleft both sides. Sandy grounds.

\section{PEDICULARIS}

Herbs, with mostly pinnatifid leaves. Flowers rather large and in spikes. Corolla strongly 2-lipped, the upper lip flattened and often beaked; the lower erect at base, 2-crested above, 3-lobed.

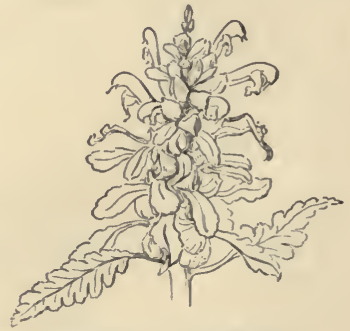

Pedicularis canadensis, Lousewort.

P. canadensis, Lousewort. Hairy; stems simple, clustered; leaves scattered, the lowest pinnately parted, the others half-pinnatifid; spike 
short and dense; calyx split in front; upper lip of the greenish-yellow and crimson corolla hooded, incurved; capsule flat, somewhat swordshaped. Thickets and banks. May, June.

\section{OROBANCHACEAE (BROOM-RAPE FAMILY)}

Yellowish or brownish, root-parasitic herbs, with no green foliage, bearing scales instead of leaves, tubular, more or less 2-lipped corolla, didynamous stamens, and a I-celled capsule with very numerous minute seeds.

\section{CONOPHOLIS}

Chestnut-colored or yellowish throughout, as thick as a man's thumb, covered with scales. Flowers in a thick scaly spike. Calyx deeply cleft in front. Corolla 2-lipped. Stamens exserted.

C. americana, CANCER-ROoT. In woods, mostly under oaks, appearing in clusters among fallen leaves. May and June.

\section{OROBANCHE}

Brownish, purplish, or whitish plants. Flowers solitary or clustered. Calyx 5-cleft. Corolla 2-lipped. Stamens included.

O. uniflora, BRoom RAPE. Stem subterranean or nearly so, very short, sending up long, I-flowered, naked scapes; divisions of calyx lance-awl-shaped; corolla with a long curved tube, 2 yellow bearded folds in the throat, and spreading obovate lobes. Damp woods. April to July.

\section{PLANTAGinaceaE (Plantain Family)}

Stemless herbs, with regular 4-merous spiked flowers, and dry, membranaceous, sympetalous corolla bearing the stamens on its tube.

\section{PLANTAGO}

Herbs with ribbed leaves. Small whitish flowers in a bracted head, on naked scape. Calyx of 4 imbricated persistent sepals. Corolla salver-form or rotate with 4 -parted border. Stamens 4 . Capsule 2-celled. 
P. cordata, Brook Plantain. Tall and glabrous; leaves fleshy, heart-shaped or round-ovate, long petioled, the ribs arising from the midrib; spike at length loosely flowered; bracts round-ovate, fleshy; seeds 2-4, not hollowed on the face. Along streams.

P. lanceolata, RiB-Grass. Mostly hairy; scape grooved-angled, at length much longer than the lanceolate or lance-oblong leaves;

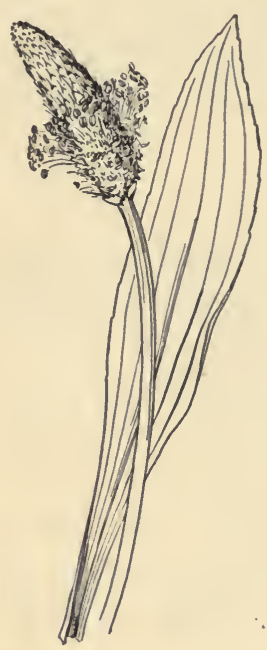

Plantago lanceolata, Rib grass. spike dense, at first capitate, in age cylindrical; bracts scarious; seeds 2 , hollowed on the face. Very common in meadows.

\section{RUBIACEAE (MADDER FAMiLy)}

Herbs or woody plants, with opposite, entire leaves connected by interposed stipules, or in ahorls; regular, epigymous flowers, stamens as many as the lobes of the regular corolla (4 or 5), and various kinds of fruit.

\section{GALIUM}

Slender herbs, with square stems, leaves in whorls, and small flowers in cymes. Corolla wheel-shaped, 4-parted. Stamens 4. Fruit dry or fleshy, globular, twin, separating when ripe into 2 seed-like carpels.

G. Aparine, Bedstraw. Stem weak and reclining, prickly backward, hairy at the joints; leaves about 8 in a whorl, lanceolate, rough on the margins and midrib; peduncles bearing I-3 white flowers; fruit bristly. Rich woods and shaded ground.

\section{HOUSTONIA}

Small herbs, with opposite leaves connected by short stipules, and cymose or solitary flowers. Corolla usually much longer than calyx. Ovary 2-celled, becoming a pod.

H. caerulea, Bluets. Small and delicate glabrous plants, with erect slender stems not higher than $2 \mathrm{dm}$.; leaves oblong-spatulate; peduncle I-flowered; corolla light blue (or nearly white), with a yellowish eye 
and a slender, long exserted tube. Wet meadows, from early spring to midsummer.

H. purpurea. Smooth or somewhat pubescent, becoming $5 \mathrm{dm}$. high; leaves varying from roundish-ovate to lanceolate; flowers in small terminal clusters; corolla funnel-form, white to purplish. Woods. May to September.

\section{CAPRIFOLIACEAE (HoNeysuckle FAMily)}

Shrubs, rarely herbs, with opposite leaves, epigynous regular flowers, stamens as many as the lobes of the tubular or rotate corolla, and inserted on its tube, and fruit a berry, drupe, or pod.
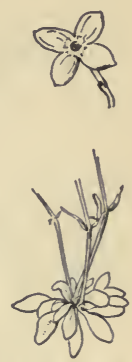

Houstonia caerulea, Bluets.

\section{DIERVILLA}

Low upright shrubs, with ovate or oblong, pointed, serrate leaves and 3-several-flowered peduncles from the upper axils or terminal. Corolla funnel-form, nearly regular, 5-lobed. Stamens 5. Pod slender, pointed, 2-celled.

D. Lonicera, Bush Honeysuckle. Leaves oblong-ovate, taperpointed, petioled; peduncles mostly 3 -flowered; flowers at first pale yellow, turning to

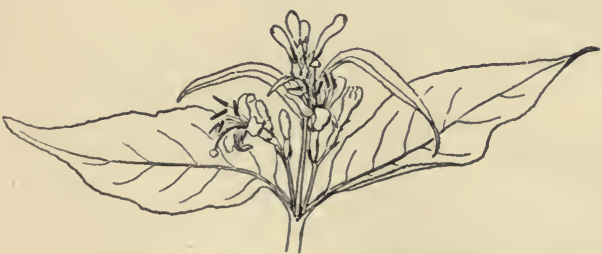

Diervilla Lonicera, Bush honeysuckle. deep yellow, scarlet, or crimson; pod long-beaked. D ry woods. June to August.

\section{LONICERA}

Erect or climbing shrubs, with entire leaves, and often showy and fragrant flowers. Corolla tubular or funnel-form, often gibbous at base, irregularly or almost regularly 5-lobed. Stamens 5. Berry several-seeded.

L. canadensis, Fly Honeysuckle. Upright shrub, with straggling branches; leaves ovate-oblong, often heart-shaped, petioled, ciliate; 
peduncles axillary, 2-flowered at summit; corolla funnel-form, greenish-yellow, the lobes much shorter than the tube; the 2 berries,

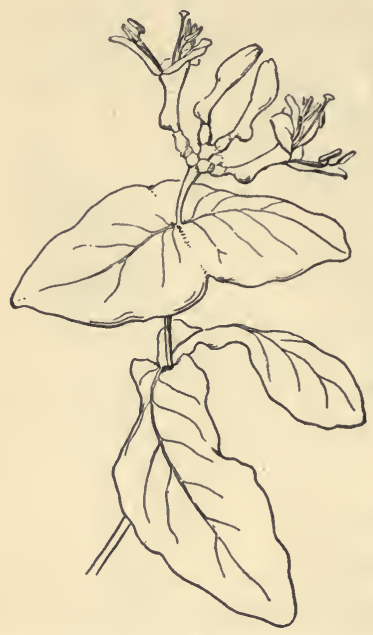

Lonicera dioica, Honeysuckle. separate, red. Woods. April to June.

L. dioica, Honeysuckle. $\mathrm{T}$ w in in $\mathrm{g}$ shrubs, glabrous; leaves oblong, glaucous and smooth beneath, the upper I-4 pairs connate into disks; even the uppermost disks somewhat oblong or rhombic, more or less pointed at each end; flowers in sessile, whorled clusters from the axils of the upper, connate leaves; corolla greenish-yellow or purplish, hirsute within the tube; berry red or orange. Rocky ground. May and June.

\section{SYMPHORICARPOS}

Low shrubs, with oval, short-petioled leaves, and white flowers in close clusters. Corolla bell-shaped, 4-5 lobed, with as many short stamens inserted in the throat. Berry 4-celled, 2-seeded.

S. racemosus, SNowberrý. Shrub becoming Io $\mathrm{dm}$. high; leaves elliptic-oblong to orbicular, green on both sides, pilose beneath; flowers I or 2, or in short spikes at the ends of the branches; corolla campanulate, bearded insicle; stamens and style included; fruit white. Dry ground. June and July.

\section{TRIOSTEUM}

Coarse, hairy, leafy herbs. Leaves large, entire, pointed, tapering to the base or connate around the simple stem. Flowers solitary or clustered on the axils. Corolla tubular, about equally 5-lobed, scarcely longer than the calyx. Ovary 3-celled, becoming a dry drupe.

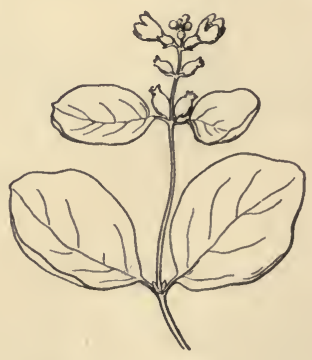

Symphoricarpos racemosus, Snowberry.

T. perfoliatum, Horse Gentian. Stem densely glandular-puberulent above; leaves dark green, oval, abruptly narrowed below to a connate- 
clasping base, the uppermost tapering or scarcely connate at base; corolla purplish to yellowish or greenish; fruits usually 6-8 at each node, dull orange-yellow. Rich woods. May and June.

\section{VIBURNUM}

Shrubs, with simple leaves and white flowers in flat-topped clusters. Corolla spreading, deeply 5-lobed. Stamens 5. Fruit a I-celled, I-seeded drupe with soft pulp.

V. acerifolium, MAPLE-LEAVEd ViburNUM. Shrubs becoming $1.5 \mathrm{~m}$. high, ; leaves downy beneath, 3-ribbed from the rounded or subcordate base, somewhat 3 -lobed, the pointed lobes diverging and unequally toothed; fruit crimson, turning purplish-black. Rocky woods. May and June.

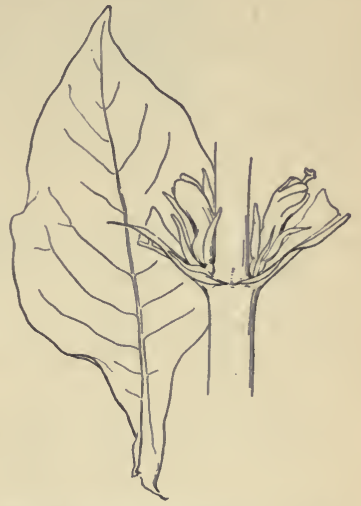

Triosteum perfoliatum, Horse gentian.

V. pubescens, Arrow-wood. Low, straggling shrub; leaves shortpetioled or subsessile, ovate or oblong ovate, cordate at base, acute

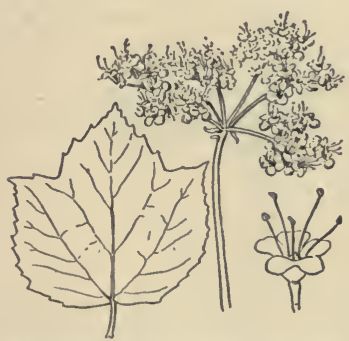

Viburnum acerifolium, Mapleleaved viburnum.

or taper-pointed, coarsely toothed, downy beneath; fruit dark purple. Rocky grounds. May and June.

V. Lentago, SweEt VIBURNUM. Shrub or tree, becoming $9 \mathrm{~m}$. high; leaves

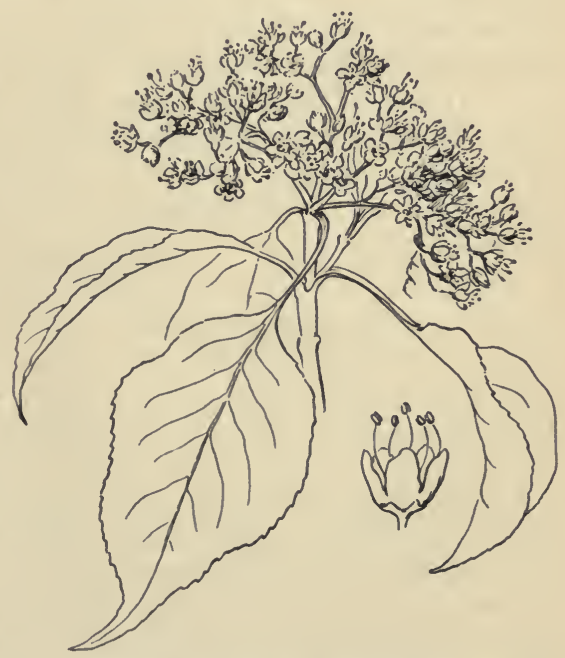

Viburnum Lentago, Sweet viburnum. 
ovate, closely and very sharply serrate, at least the upper caudateacuminate and on winged petioles; cyme sessile, 3-4 rayed; fruit blueblack. Woods. May and June.

V. prunifolium, BLACK HAw. Tall shrub or small tree; leaves oval, obtuse, finely and sharply serrate, the lower surfaces and petioles glabrous; cyme 3-5-rayed; fruit similar to the last. Dry or moist ground. May and June.

\section{SAMBUCUS}

Shrubby, with pinnate leaves, serrate-pointed leaflets, and numerous small flowers in large flat-topped clusters. Corolla often urn-shaped, with a spreading 5-cleft border. Stamens 5. Fruit a berry-like, juicy drupe containing 3 seed-like nuts.

S. racemosa, RED-BERRIED ElDER. Stems woody, with warty bark and brown pith; leaflets $5-7$, ovate-lanceolate, downy beneath; cymes panicled, convex, or pyramidal; flowers yellowish-white; fruit bright red. Rocky woods. May and June.

\section{COMPOSITAE (Composite Family)}

The largest family of flowering plants, with epigynous flowers in a close head on a common receptacle surrounded by an involucre, tubular corolla with 5 stamens inserted in the throat, and fruit seed-like (achene) and crowned by the calyx in the form of bristles, scales, awns, teeth, etc. (pappus).

\section{ERIGERON}

Herbs, with entire or toothed leaves, and solitary or corymbed heads. Heads many-flowered, on naked peduncles. Disk yellow; rays white, pink, or purple. Involucre of narrow equal bracts. Achenes flattened; pappus of long bristles, rather scanty.

E. pulchellus, Fleabane. Hairy, producing offsets from the base; stem simple, rather naked above, bearing few large heads on slender peduncles; basal leaves obovate or spatulate, sparingly toothed, the cauline ones distant, lanceolate-oblong, partly clasping, entire; rays (about 50) rather broad, light bluish-purple. Open ground and moist banks. April to June. 
E. philadelphicus, Fleabane. Hairy; stem leafy, corymbed, bearing several small heads; leaves oblong, the upper clasping by a heartshaped base, entire, the lowest spatulate, toothed; rays much more numerous, very narrow, rose-purple or flesh-color. Generally in rich soil. May to August.

\section{ANTENNARIA}

White-woolly herbs, with e $\mathrm{n}$ tir e leaves and corymbose or race mose heads. Heads many-flowered, dioecious; flowers all tubular. Involucre dry and scarious, white or colored, imbricated. A $\mathrm{ch}$ e n e s terete or flattish; pap-
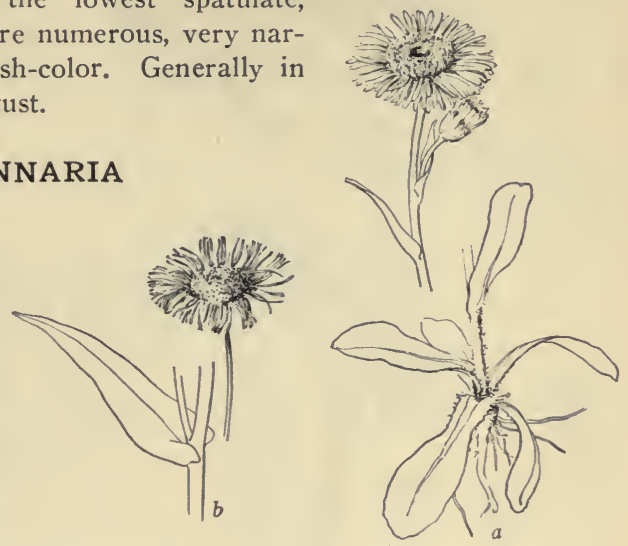

Erigeron, Fleabane; $a, E$. pulchellus; $b, E$. philadelphicus. pus a single row of bristles.

A. canadensis, Everlasting. Forming broad mats; stems slender; basal leaves small, spatulate to oblanceolate; stem leaves scattered;

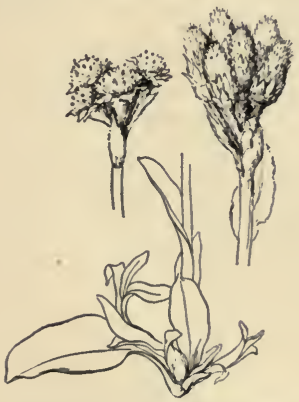

Antennaria, Everlasting; staminate inflorescence (left); pistillate inflorescence (right); base of stem. heads loosely corymbose; styles pale, drying brownish. Dry soil. May to July.

A. plantaginifolia, P L A N T A I N-LEAVED EverLasting. Basal leaves from broadly ovate to oblanceolate; stem leaves scattered, lanceolate; heads loosely or densely corymbose; styles crimson. Dry soil. April to June.

\section{RUDBECKIA}

Herbs, with alternate leaves, and showy terminal heads. Heads many-flowered, with yellow rays. Bracts of the involucre leaf-like, spreading. Receptacle conical or columnar. Achenes 4-angled, smooth, with no pappus.

R. hirta, Black-Eyed Susan. Very rough and bristly-hairy throughout; stems simple or branched near the base, naked above, bearing 


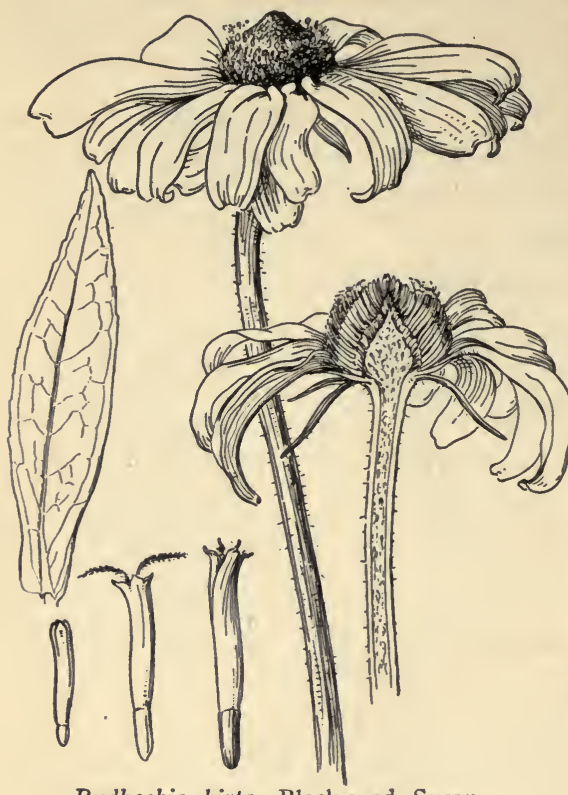

Rudbeckia hirta, Black-eyed Susan.

single large heads; leaves nearly entire, the upper oblong or lanceolate, sessile; the lower spatulate; disk dark purple or brown. Dry soil. June to September.

\section{COREOPSIS}

Herbs, generally with opposite leaves, and manyflowered heads with yellow or parti-colored rays. Involucre double, each series of about 8 bracts, the outer leaf-like and s p r e a ding, the inner broader and appressed. Receptacle flat. Achenes flat, often winged, 2toothed or 2-awned.

C. lanceolata, TICKSEED. Smooth or hairy, tufted, branched only at base; leaves all entire; lanceolate; the lowest oblanceolate or spatulate; achenes with broad, thin, spreading wings. Rich soil. May to July.

\section{ACHILLEA}

Herbs, with small corymbose heads. Heads many-flowered with a few rays. Bracts of involucre imbricated, with scarious margins. Achenes oblong, flattened, margined; pappus none.

A. Millefolium, YarRow. Stem simple or forked above, woolly or nearly smooth; stem leaves numerous, smooth or somewhat pubescent; cormybs very compound, flat-

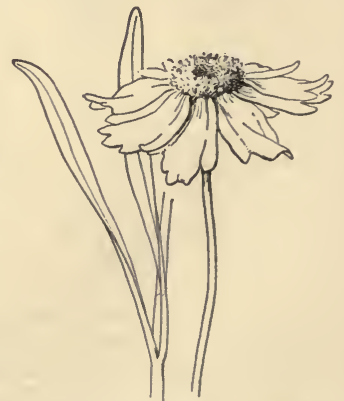
topped; bracts of involucre pale; rays 5-10, white to crimson. Fields and banks. 


\section{CHRYSANTHEMUM}

Herbs, with toothed, pinnatifid, or divided leaves, and single or corymbed heads. Heads many-flowered, with yellow disk and white or yellow rays. Scales of the broad involucre imbricated and with scarious margins. Receptacle flat or convex. Achenes striate.

\section{Leucanthemum, Ox-EYE DAIsy. Stem} erect, simple or forked; basal leaves spatulateobovate, on long slender petioles, the blades erenate-dentate; middle and upper stem-leaves oblong or oblanceolate, coarsely toothed; involucral bracts narrow, brown-margined; rays white. Fields. June to August.

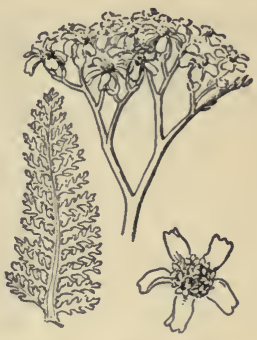

Achillea Millefolium, Yarrow.

\section{SENECIO}

Herbs, with alternate leaves and solitary or corymbed heads. Heads many-flowered, with yellow rays. Involucre cylindrical to bell-shaped, sometimes with a few bractlets at base. Receptacle flat. Pappus of numerous very soft and capil-

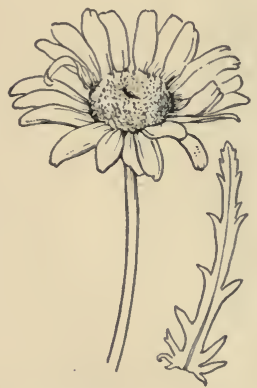

Chrysanthemum Leucan. themum, Ox-eye daisy. lary bristles.

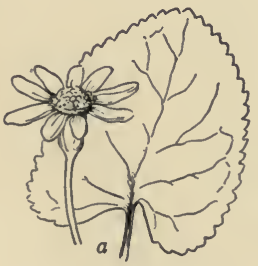

Senecio, Ragwort; $a$, S. aureus; $b$, S. Balsamitae, showing variation of leaves.

S. aureus, Golden Ragwort. Stems erect, at first tomentose, soon glabrate; lower leaves long-petioled, round-ovate to slightly oblong, crenate-dentate; stem leaves lyrate to laciniate-pinnatifid; uppermost sessile and clasping; achenes glabrous. 


\section{KRIGIA}

Small herbs, branched from the base, with chiefly radical leaves, and small heads terminating naked scapes or branches. Heads

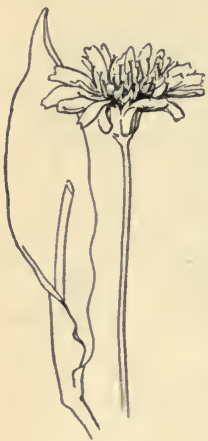

Krigia

amplexicaulis. several to many-flowered, with yellow rays. Involucre bracts in about 2 rows, thin. Achenes short and truncate, terete or angled; pappus double, the outer of thin scales, the inner of delicate bristles.

K. virginica, DWARF DANDELION. Scapes several, up to $3 \mathrm{dm}$. high, becoming branched and leafy; earlier leaves roundish and entire, the others narrow and often pinnatifid; bracts of involucre 9I8, reflexed in age; achenes 5angled; pappus of $5-7$ short scales and as many alternating bristles. Dry ground. April to August.

K. amplexicaulis, CyNTHIA. Stem up to $6 \mathrm{dm}$. high; stemleaves I-3, oblong or oval, clasping, mostly entire; the radical ones on short winged petioles, often toothed; bracts of involucre as in the last; achenes more slender; pappus of 10-15 small scales and 15-20 bristles. Moist banks. May to August.

\section{TARAXACUM}

Herbs with pinnatifid or

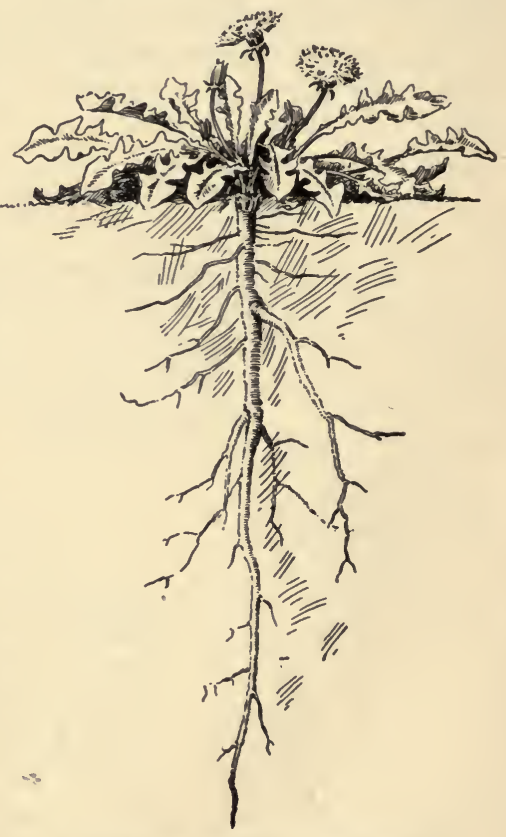

Taraxacum officinale, Dandelion.

runcinate radical leaves, and a large solitary head on a slender hollow scape. Heads many-flowered, with yellow rays. Involucre double, the outer of short bracts, the inner of long, linear, erect bracts. Achenes oblong-ovate to fusiform, 4-5 ribbed, the apex 
prolonged into a very slender beak which bears at its tip the copious soft white pappus.

T. officinale, DANDELIoN. Leaves coarsely pinnatifid, sinuatedentate; heads large, orange-yellow, outer involucral bracts elongated and conspicuously reflexed; achenes olive-green or brownish. Open ground everywhere. April to September. 


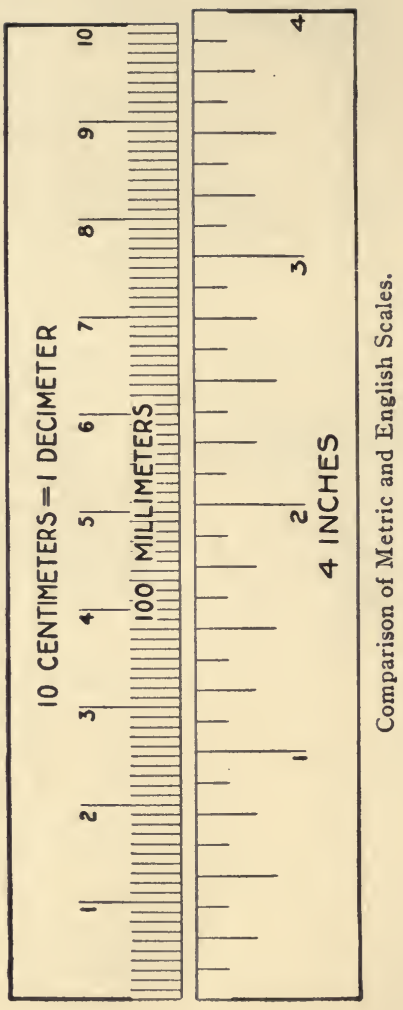




\section{GLOSSARY}

Achene. A small, one-seeded fruit, as in dandelion or strawberry.

Adnate. United throughout entire length, as anthers adnate to each other.

-androus. Referring to the number of stamens, as 6-androus.

Annual. Applied to plants which complete their life cycle in one growing season, perishing at approach of winter.

Apetalous. Without petals.

Aril. A growth about the seed, as in certain gymnosperms.

Aromatic. With pungent fragrance.

Attenuate. Tapering slenderly.

Auricled. Having ear-shaped appendages.

Awl-shaped. Tapering from the base into a slender or rigid point.

Awned or Awn-pointed. Having a bristle-like appendage.

Axillary. Located in the upper angle formed by a leaf with the stem.

Biennial. Applied to plants which complete their life cycle in two growing seasons.

Bloom. A delicate down which may be removed by rubbing, as the bloom on grapes.

Bracts. Small, leaf-like organs usually subtending flowers.

Campanulate. Bell or cup-shaped.

Capillary. Hair-like.

Capitate. Head-like. Applied to dense and globose inflorescences.

Capsule. A dry, dehiscent fruit composed of two or more carpels.

Carpel. A simple pistil or one part of a compound pistil; a megasporophyll.

Catkin. A scaly, dense, spike-like, and usually flexible inflorescence, as in the birches and poplars.

Caudate. Having a tail-like appendage.

Cauline. Related to the stem.

-celled. Used of the ovule-containing chambers of an ovary, as, ovary 2-celled. Not to be confused with cells, the microscopic units of structure of organisms.

Chaffy. Bearing numerous small and thin scales which become dry and membranous, as in the heads of some Compositae.

Ciliate. Having the margin fringed with fine hairs.

Coherent. Said of structures which are more or less attached to each other.

Connate. Closely united.

Connivent. Said of structures which are in contact.

Corm. The enlarged fleshy base of a stem, bulb-like but solid, as indian turnip.

Corymb. A flat or convexly topped inflorescence whose pedicels are of unequal length and whose youngest flowers are at the center.

Crenate. Tooth-margined, but the teeth much rounded.

Crustaceous. Hard and brittle.

Cyme. An inflorescence, usually flat-topped, with the oldest flowers at the center. 
Decompound. More than once compounded or divided.

Dentate. Tooth-margined.

Diadelphous. Said of the stamens when they are arranged in two sets.

Didynamous. Said of the stamens when they are arranged in two pairs of unequal length.

Dioecious. Said of plants having staminate and pistillate flowers on different individuals.

Discoid. Disk-like.

Disk. A structure appearing in certain flowers, as in Umbelliferae. It is a cushion-like outgrowth of the receptacle around the base of the pistil.

Divergent. Spreading abruntly apart.

Drupe. A fleshy fruit with a central stone or pit, as a peach.

Endocarp. The inner layer of the ovary wall.

Ephemeral petals. Those which last for only one day.

Epicarp. The outer layer of the ovary wall.

Epigynous. Said of flowers whose perianth arises above the ovary.

Exfoliate. To peel off in thin layers.

Filament of stamen. The part which supports the anther.

Filiform. Thread-form.

Flaccid. Without rigidity, wilted.

Flocculent. Pearing soft wool-like hair in small masses.

-foliolate. Referring to the leaflets, as trifoliolate.

Fugacious. Said of petals or sepals which fall or fade very early.

Glabrate. Somewliat glabrous, or becoming so.

Glabrous. Smooth. Free from hairs.

Glaucous. Having a bloom.

Glutinous. Sticky, like the gluten of wheat.

Granulate. Bearing minute grains.

Halberd-form. Like an arrow-head in form, but the basal lobes turned out nearly

- at right angles.

Hirsute. Stiff-laairy.

Hispid. Bearing rigid or bristly hairs.

Hybrid. A form resulting from the crossing of different species.

Hydrophyte. An aquatic plant or one growing in very wet places.

Hypogynous. Said of flowers whose perianth arises beneath the ovary.

Imbricated. Overlapping, as frequently the sepals or petals in buds.

Imperfect flowers. Flowers which lack one or the other of the essential parts; they are either staminate or pistillate.

Incised. Having the margin as if cut sharply and irregularly.

Included stamens. Those which do not protrude at all from the corolla tube.

Indehiscent. Not opening at maturity, as many kinds of fruits.

Inferior ovary. Equivalent to epigyny.

Internodes. The spaces between the nodes or joints of the stem.

Involucel. A secondary involucre.

Involucre. A whorl of bracts surrounding an inflorescence or a single flower. Characteristic of Compositae.

Keel. Applied to the two united petals of many flowers of Leguminosae which simulate the form of the keel of a boat, as in sweet-pea or clover. 
Lacerate. Having the margin roughly cleft, as if torn.

Lanceolate. Said of leaves shaped like a lance-head, several times longer than wide.

Lenticel. The spongy pores in bark which permit transfusion of gases. Especially conspicuous in birch.

Lyrate. Pinnately cleft, the terminal lobe being rounded and consicuously larger than the others.

Membranous. Thin, dry, and more or less translucent.

Monadelphous. Said of stamens which are united by their filaments into a tube or column.

Monoecious. Said of plants having staminate and pistillate flowers on the same mdividual.

$O b$-. A prefix giving the idea of inversion.

Obcordate. Inverted heart shape, said of leaves with the broad part of the heart away from the stem.

Obovate. Inverted ovate.

Obovoid. Inverted ovoid.

Obscurely toothed. Very slightly toothed.

Obtuse. Blunt or rounded at the end.

Ovate. Egg-shaped. Said of leaves with an outline like an egg with the broader end down.

Ovoid. Nearly oval in outline.

Palmate. Said of leaves which are radiately lobed or divided, suggestive of the palm and fingers of the hand.

Panicle. A loose and irregularly compound inflorescence whose flowers are on pedicels.

Papilanaceous. Said of corollas like that of pea and of many other Leguiminosae.,

Papillose. Bearing minute, nipple-shaped projections.

Pappus. The modified calyx of Compositae. It forms a crown of various character at the top of the achene.

Pedicel. The stalk of a single flower.

Peduncle. A primary flower-stalk, supporting either an inflorescence or a solitary flower.

Perennial. Lasting year after year.

Perfect. Said of flowers which have both kinds of essential parts, $i$. $e$ :, stamens and carpels.

Perfoliate. Said of leaves through which the stem appears to pass.

Perianth. The accessory parts of a flower, $i$. e., calyx and corolla.

Perigynous flowers. Those intermediate in structure between hypogyny and epigyny; the calyx adnate to the ovary.

Pinna. One of the divisions of a pinnate leaf.

Pinnate leaves. Compound, divided into pinnae, on the plan of a feather; the leaflets arranged on each side of a common petiole.

Pinnatifid. Pinnately cleft.

Pinnule. $\Lambda$ secondary pinna of a decompound lesf.

Pistillate flowers. Flowers with pistil, but no stamens.

Placenta. Any part of the interior of the ovary which bears ovules.

Polygamo-dioecious. Said of plants which, like the maples, are polygamous, with a tendency to be dioecious.

Polygamo-monoecious. Polygamous with a tendency to be monoecious.

Polygamous. Said of plants which produce both perfect and imperfect flowers.

SPRING FLOI.A-9 
Polypetalous. Said of flowers whose petals are separate.

Pome. A kind of fleshy fruit of which apple is the type.

Procumbent. Prostrate, but without taking root at the nodes.

Pubescent. Covered with short hair, as the pubescence of a peach.

Raceme (adj., racemose). A simple inflorescence of about equi-pediceled flowers on a common stalk; example, lily-of-the-valley.

Radical leaves. Those which arise from the base of the stem, so near the ground as to have the appearance of arising from the root.

Ray. Applied to one of the branches of an umbel, as in Zizia.

Ray flowers. The marginal flowers in a composite head.

Receptacle. The more or less expanded top of the stalk (pedicel or peduncle)

from which the flowers arise.

Reticulated. Characterized by a net-like pattern; net-veined.

Retrorse prickles. Those directed back or downward.

Revolute margin. One which tends to roll back.

Rhizome. A subterranean or only prostrate stem.

Rootstock. Same as rhizome.

Rotate corolla. One which is flat and circular in outline: wheel-shaped.

Runcinate. Sharply incised with the segments directed backwards.

Saccate. Sac-shaped, as the bottom of the corolla in violet.

Sagittate. Shaped like an arrow-head with the lobes directed down.

Salver-form. Said of a corolla composed of a slender tube abruptly expanding into a flat top; the form of the antique salver.

Samara. An indehiscent winged fruit like that of maples; "key" fruit.

Scape. A peduncle rising from the ground and without foliage, as in tulip.

Scarious. Thin, dry, not green.

Scurfy. Rough with short, woolly hairs.

Serrate. Said of margins with sharp teeth pointing forward.

Serrulate. Finely serrate.

Sessile. Without stalk. Said of leaves without petioles, anthers without filaments, etc.

Sinuate-toothed. A toothed margin with a tendency to be wavy.

Sinus. The cleft between two lobes, as in a cordate leaf.

Spadix. A flower-bearing, fleshy axis, as in jack-in-the-pulpit.

Spathe. A large bract, or pair of them, usually hood-shaped, enclosing an inflorescence, as in skunk cabbage or jack-in-the-pulpit.

Spatulate. Having the shape of a spatula; gradually narrowing down from a rounded summit.

Sporangium. A spore case. Obvious in pteridophytes; in spermatophytes, the pollen-sacs are examples.

Spore. A unicellular reproductive body capable of direct growth into a new individual.

Sporophyll. A spore-bearing organ, leaf-like in origin and sometimes in appearance, as the sporophylls of the common ferns. Among seed plants the stamens are sporophylls, and the young pollen grains are spores.

Spur. A sac-like extension of the corolla as in violet or nasturtium.

Staminate flowers. Those which have stamens but no pistils.

Stigmatic surface. The pollen-catching surface.

Stipe. The leaf-stalk of a fern.

Stipule. An outgrowth at the base of the petiole or on each side of it, as in the rose family. 
Stolon. A prostrate stem or runner which tends to take root and branch, as in strawberry.

Strigose. Covered with sharp, straight, and stiff hairs which tend to lie flat. Stylopodium. The expansion at the base of the style, as in Umbelliferae.

Subcylindric. Somewhat cylindric.

Sympetalous. Said of corollas whose petals are more or less united.

Ternate. In threes.

Tomentose. Densely, woolly pubescent, as mullein leaves.

Trifoliolate. Having three leaflets.

Truncated. Ending abruptly; as if cut off.

Tuberous. Tuber-like.

Umbel. An inflorescence whose pedicels or peduncles arise from the same place. Characteristic of Umbelliferae.

Valvate. Opening by valves, as a capsule.

Valve. One of the segments into which a capsule or pod splits.

Vascular bundle. One of the groups of conducting and supporting tissue which are characteristic of vascular plants.

Vernal. Flowering in early spring.

Villous. Bearing long and soft hairs.

Whorl. The arrangement of leaves or flower parts in circles, or groups, at the nodes. 



\section{N D E X}

Latin names of families are in SMALL CAPITALS

Acer, 91.

Negundo, 92.

rubrum, $9 \mathrm{I}$.

saccharinum, 91.

Aceraceae, 91.

Achillea, I22.

Millefolium, I22.

Acorus, 33.

Calamus, 34 .

Actaea, 64 . alba, 64 .

Adder's Tongue, 36.

Yellow, 36.

White, 36.

Aesculus, 92. glabra, 92.

Alder, Smooth, 49.

Speckled, 49.

Allium, 35.

canadense, 35 .

Alnus, 49.

incana, 49.

rugosa, 49 .

Alsike Clover, 83.

Alternate-leaved Dogwood, 100.

Alum Root, 74 .

A MARYLLIDACEAE, 40.

Amaryllis Family, 40.

Amelanchier, 77.

canadensis, 77.

oblongifolia, 77 .

American Elm, 52.

Anacardiaceae, 89.

Andromeda, I02.

glaucophylla, 102.

Anemone, 6r.

canadensis, 62.

quinquefolia, 62 .

Rue, 6 I.

Wood, 62.

Anemonella, 6r.

thalictroides, $6 \mathbf{r}$.

Anonaceae, 65.
Antennaria, 121.

canadensis, I2I.

plantaginifolia, I2I.

AQuifoliaceae, 89.

Aquilegia, 63.

canadensis, 64.

Arabis, 73. lævigata, 73 . lyrata, 73 .

Araceae, 32.

Aralia, 97.

nudicaulis, 97.

Araliaceae, 97.

Arbor Vitæ, 32.

Arbutus, Trailing, I03.

Arctostaphylos, I03. Uva-ursi, 103.

Arenaria, 55. lateriflora, 56 . serpyllifolia, 56.

Arisæma, 33. triphyllum, 33.

Aristolochiaceae, 54.

Arrow-leaved Violet, 95.

Arrow-wood, II9.

Arum Family, 32.

Asarum, 54. canadense, 55 .

Ash, Black, ro6.,

Mountain, 77.

Prickly, 87.

White, 106.

Asimina, 65.

triloba, 66.

Aspen, Large-toothed, 44. Trembling, 44.

Azalea, Purple, I02.

Balsam, Poplar, 44.

Baneberry, White, 64 .

Barbarea, 72.

vulgaris, 72.

Barberry, 67. 
Barberry Family, 66.

Basswood, 93.

Bastard Toadflax, 54 .

Bayberry, 45.

Bearberry, I03.

Bedstraw, I I6.

Beech, 50.

Blue, 48.

Family, 49.

Bellwort, 35 .

Benzoin, 68. aestivale, 68.

BeRberidaceae, 66.

Berberis, 67.

Betula, 48 . vulgaris, 67 .

alba papyrifera, 49 .

lenta, 48.

lutea, 48.

nigra, 48 .

populifolia, 49 .

Betulaceae, 47.

Birch, Canoe, 49.

Family, 47.

River, 48.

Sweet, 48.

White, 49.

Yellow, 48.

Bird-foot Violet, 95.

Birthwort Family, 54.

Bishop's Cap, 75 .

Bitter Cress, 73.

Bitternut, Hickory, 47.

Bittersweet, 90.

(Nightshade), I I2.

Black, Ash, I06.

Currant, Wild, 75.

Haw, I20.

Medick, 84 .

Mustard, 72.

Oak, 52.

Raspberry, 8I.

Walnut, 46.

Willow, 42.

Blackberry, Swamp, 8I.

Tall, 8I.

Black-eyed Susan, I2I.

Bladder Nut, 9I.

Nut Family, 90.

Bloodroot, 69.

Blt:e Beech, 48.

Cohosh, 67.

Flag, 4I.
Phlox, 107.

Violet, 95.

Blueberry, 104.

Low, 104.

Swamp, I04.

Blue-eyed Grass, 4r. Mary, II3.

Bluets, I I6.

Bog Rosemary, I02.

Borage Family, IO9.

Boraginaceae, IO9.

Box Elder, 92.

Brassica, 7I.

arvensis, $7 \mathrm{I}$.

nigra, 72 .

Brook Plantain, II6.

Broom-rape Family, II5.

Broom Rape, II 5.

Buckbean, I07.

Buckeye, 92.

Bunchberry, 100.

Bur Oak, 50.

Bur-reed, 32.

Family, 32.

Bush Honeysuckle, II7.

Buttercup, Common Swamp, 60.

Early, 59.

Small-flowered, 59.

Swamp, 60.

White Water, 59.

Yellow Water, 59.

Butternut, 46.

Cabbage, Skunk, 33.

Calamus, 34 .

Caltha, 62.

palustris, 62 .

Camassia, 36.

esculenta, 36.

Canada Violet, 95.

Cancer-root, II5.

Canoe Birch, 49.

CAPrifoliaceae, II7.

Capsella, 7 I.

Bursa-pastoris, $7 \mathrm{I}$.

Cardamine, 73.

bulbosa, 73 .

Douglasii, 73.

pennsylvanica, 73 .

Carpinus, 48.

caroliniana, 48.

Carrion-flower, 40.

Carya, 46. 
Carya cordiformis, 47. glabra, 47. ovata, 46.

Cashew Family, 89.

Castilleja, II4. coccinea, II4.

Catchfly, 'Sleepy, 57.

Caulophyllum, 66. thalictroides, 67 .

Cedar, Red, 32. White, 32.

Celandine Poppy, 69.

Celastraceae, 90.

Celastrus, 90. scandens, 90.

Celtis, 53. occidentalis, 53.

Cerastium, 56. nutans, 57. vulgatum, 57 .

Cercis, 82. canadensis, 82.

Chærophyllum, 98. procumbens, 98 .

Chamædaphne, I02. calyculata, IO2.

Charlock, 7I.

Cherry, Choke, 80. Sand, 8 o.

Wild Black, 80.

Wild Red, 80.

Chervil, 98.

Chestnut Oak, 50, 5I.

Chickweed, 56.

Common Mouse-ear, 57.

Mouse-ear, 57.

Chokeberry, 77.

Chokecherry, 80.

Chrysanthemum, I23.

Leucanthemum, I23.

Cinquefoil, common, 79.

Rough, 78.

Silvery, 78 .

Cistaceae, 94.

Claytonia, 57. virginica, 58 .

Cleft Phlox, I08.

Clover, Alsike, 83.

Red, 83.

Sweet, 84 .

White, 83 .

Cohosh, Blue, 67 .

Collinsia, II 3 . verna, II3.

Columbine, 64 .

Comandra, 54. umbellata, 54 .

Com Melin aceae, 34 .

Common Cinquefoil, 79.

Locust, 84.

Mallow, 93.

Mouse-ear Chickweed, 57.

Swamp Buttercup, 60.

Compositae, i2O.

Conopholis, II5.

americana, II5.

Coptis, 62.

trifolia, 63 .

Coreopsis, I22.

lanceolata, I22.

Cornaceae, ioo.

Cornus, roo. alternifolia, Ioo. canadensis, Ioo.

florida, IOo.

paniculata, Ioo.

stolonifera, 100.

Corylus, 47. americana, 47.

Cottonwood, 45.

Cow Parsnip, 99.

Crab, Wild, 77.

Cratægus, 77.

coccinea, 78 .

Cress, Bitter, 73 .

Pennsylvania Bitter, 73.

Rock, 73.

Smooth Rock, 73.

Spring, 73.

Winter, 72.

Crowfoot Family, 58.

CRuciferae, 70.

Cryptotænia, 99.

canadensis, 99.

Cucumber-root, 38.

Tree, 65.

Currant, Wild Black, 75.

Custard Apple Family, 65.

Cynoglossum, rog.

officinale, Iog.

Cynthia, I24.

Cypress Spurge, 88.

Daisy, Ox-eye, I23.

Dandelion, I25.

Dwarf, I24. 
Delphinium, 64.

Dentaria, 72. diphylla, 72 . laciniata, 72 .

Dewberry, 8I.

Dicentra, 69. canadensis, 70. Cucullaria, 69.

Diervilla, II7. Lonicera, II7.

Dirca, 96.

palustris, 96.

Disporum, 37. lanuginosum, 38 .

Dodecatheon, 105. Meadia, I05.

Dogwood, Alternate-leaved, Ioo. Family, Ioo.

Flowering, Ioo.

Panicled, I0o.

Red-osier, Ioo.

Dog's-tooth Violet, 36.

Draba, 70. caroliniana, 7I,

Dutchman's Breeches, 69.

Dwarf Dandelion, I24.

Raspberry, 8I.

Early Buttercup, 59.

Meadow Rue, 60 .

Saxifrage, 74 .

Elaeagnaceae, 96.

Elder, Box, 92. Red-berried, I20.

Elm, American, 52.

Slippery, 52.

White, 52 .

Epigæa, I02. repens, I03.

EQUisetaceae, 29.

Equisetum, 30. arvense, 30 .

ERICACEAE, IOI.

Erigenia, 98. bulbosa, 98 .

Erigeron, I20. philadelphicus, I2I. pulchellus, I2O.

Erythronium, 35. albidum, 35 . americanum, 35 .

Euphorbia, 88.

Cyparissias, 88.
Euphorbiaceae, 88.

Everlasting, I2I.

Plantain-leaved, I2I.

Euonymus, 90.

Americanus obovatus, IO. atropurpureus, 90.

Fagaceae, 49.

Fagus, 49. grandiflora, 50.

False Hellebore, 34 . Mermaid, 88. Mermaid Family, 88. Mitrewort, 74 . Solomon's Seal, 36.

Fern, Cinnamon, 29. Flowering, Family, 29. Interrupted, 29. Royal, 29.

Figwort, II3. Family, II2.

Flag, Blue, 4I.

Sweet, 34 .

Fleabane, I2O, I2I.

Floerkea, 88.

proserpinacoides, 88.

Flowering Dogwood, Ioo.

Fly Honeysuckle, I 7 .

Forget-me-not, I Iо.

Fragaria, 78 .

vesca, 78 .

virginiana, 78 .

Fragrant Sumac, 89.

Fraxinus, 105. americana, I06. nigra, Io6.

Frost Grape, 93.

Frostweed, 94.

Fumariaceae, 69.

Fumitory Family, 69.

Galium, I I6.

Aparine, I 16.

Garlic, 35.

Wild, 35 .

Gaylussacia, I03. baccata, IO3.

Gentian, Family, Io6. Horse, II8.

Gentianaceae, io6.

Geraniaceae, 86.

Geranium, 86.

Family, 86. 
Geranium maculatum, 86. Wild, 86.

Ginger, Wild, 55.

Ginseng, Dwarf, 97. Family, 97.

Gleditsia, 82. triacanthos, 82.

Golden Alexanders, 99. Ragwort, I23.

Goldthread, 63.

Gooseberry, 75. Prickly, 75. Smooth, 75.

Grape, Frost, 73.

Northern Fox, 92.

Summer, 92.

Grass, Blue-eyed, 4I.

Rib, I 16.

Whitlow, 7I.

Yellow-eyed, 4I.

Great Solomon's Seal (See Large Solomon's Seal), 38.

Gromwell, IIo.

Ground Hemlock, 30.

Ivy, III.

Gum, Sour, IoI.

Hackberry, 53.

Harbinger of Spring, 98.

Haw, Black, I20.

Red, 78.

Hazelnut, 47.

Heath Family, Iог.

Helianthemum, 94. canadense, 94 .

Hellebore, False, 34 .

Hemlock, 3I. Ground, 30.

Henbit, II2.

Hepatica, 61. acutiloba, 6r. triloba, 6I.

Heracleum, 99. lanatum, 99.

Heuchera, 74. americana, 74. hispida, 74 .

Hickory, Bitternut, 47.

Pignut, 47.

Shag-bark, 46.

Holly Family, 89. Mountain, 89.

Honewort, 99.
Honey Locust, 82.

Honeysuckle, I I8.

Bush, II7.

Family, II7.

Fly, II7.

Swamp, IoI.

Hop Hornbeam, 47. Tree, 87.

Hornbeam, Hop, 47.

Horse Gentian, II8.

Horsetail, 29.

Common, 30 .

Family, 29.

Hound's Tongue, 109.

Houstonia, II6. cærulea, II6. purpurea, II7.

Huckleberry, I03.

Hudsonia, 94. tomentosa, 94.

Hyacinth, Wild, 36.

HYDROPHYLLACEAE, IO8.

Hydrophyllum, ro8.

appendiculatum, Iog.

canadense, I09.

virginianum, Iog.

Hypoxis, 40.

hirsuta, 4I.

Ilex, 89.

verticillata, 89 .

Indian Turnip, 33.

IRIDACEAE, 4I.

Iris, 4 I.

Family, 4I.

versicolor, 4I.

Isopyrum, 62 .

biternatum, 62 .

Ivy, Ground, III.

Jack-in-the-Pulpit, 33 .

Jacob's Ladder, I08.

JUGLANDACEAE, 45.

Juglans, 46. cinerea, 46. nigra, 46.

Juniper, 32.

Juniperus, 32. communis, 32. virginiana, 32 .

Kalmia, 102. latifolia, I02. 
Krigia, I24. virginica, I24.

LABIATAE, III.

Labrador Tea, IoI.

Lamium, III. amplexicaule, II2.

Lance-leaved Violet, 95.

Larch, 3I.

Large Solomon's Seal, 38.

Large-toothed Aspen, 44.

Larix, 3I. laricina, $3 \mathrm{I}$.

Larkspur, 64.

Lathyrus, 85 . ochroleucus, 85 . palustris, 85 . venosus, 85 .

LAURACEAE, 67.

Laurel, Family, 67.

Mountain, I02.

Leather Leaf, I02.

Leatherwood, 96.

Ledum, IoI. groenlandicum, IOI.

LEgUMiNOSAE, 82.

Lepidium, 7I. apetalum, 7I. virginicum, $7 \mathrm{I}$.

LILIACEAE, 34 .

Lily Family, 34. Lily-of-the-Valley, 37. Yellow Pond, 58.

LimNANTH ACEAE, 88.

Linaria, II2.

canadensis, II2. vulgaris, II 2 .

Linden, Family, 93.

Liriodendron, 65. Tulipifera, 65.

Lithospermum, IIO. arvense, IIO. canescens, III. Gmelini, II I.

Locust, Common, 84 . Honey, 82.

Lonicera, II7. canadensis, II7. dioica, II 8 .

Loosestrife, Tufted, Ic4.

Lousewort, I I4.

Lungwort, I Io.

Lupine, 82.
Lupinus, 82. perennis, 82 . Lysimachia, I04. thyrsiflora, I04.

Madder Family, I 6.

Magnolia, 65 . acuminata, 65 . Family, 65.

Magnoliaceae, 65.

Maianthemum, 37. canadense, 37.

Mallow, Common, 93. Family, 93.

Malva, 93. rotundifolia, 93.

Malvaceae, 93.

Maple Family, 91. Red, 9I.

Silver, 9I.

Sugar, 9I.

Maple-leaved Viburnum, II9.

Marigold, Marsh, 62.

Marsh Marigold, 62. Pea, 85.

May Apple, 66.

Meadow Rue; Early, 60.

Medeola, 38. virginiana, 38 .

Medicago, 84. lupulina, 84 .

Medick, Black, 84 .

Melilot, Yellow, 83.

Melilotus, 83. alba, 84 . officinalis, 83

Menyanthes, I06. trifoliata, 107.

Mertensia, IIo. virginica, I Io.

Mezereum, Family, 96.

Milkwort, Family, 87.

Mint, Family, III.

Mitella, 75. diphylla, 75 .

Mitrewort, False, 74 .

Morus, 53. rubra, 53.

Mountain Ash, 77. Holly, 89. Laurel, I02.

Mouse-ear Chickweed, 57.

Chickweed, Common, 57. 
Mulberry, Red, 53.

Mustard, Black, 72. Family, 70 .

Myosotis, I09. laxa, ino. virginica, IIo.

Myrica, 45. asplenifolia, 45 . carolinensis, 45.

Myricaceae, 45.

Nemopanthus, 89. mucronata, 89 .

Nepeta, III. hederacea, III.

Nettle Family, 52.

Nightshade Family, II2.

Nine-bárk, 76 .

Northern Fox Grape, 92.

Nymphæa, 58. advena, 58 .

Nymphaeaceae, 58.

Nyssa, IOI. sylvatica, IOI.

Oak, 50.

Black, 52.

Bur, 50.

Chestnut, 50, $5 \mathrm{I}$.

Pin, 51.

Post, 50.

Red, 5I.

Scarlet, 52.

Shingle, 7.

Swamp White, 50.

White, 50 .

Oakesia, 35. sessilifolia, 35 .

Oleaceae, 105.

Oleaster Family, 96.

Olive Family, I05.

OROBANCHACEAE, II5. uniflora, II5.

Orobanche, II5.

Osmorhiza, 98.

Claytoni, 98. longistylis, 98.

Osmunda, 29. cinnamomea, 29.

Claytoniana, 29. regalis, 29.

OSMUNDACEAE, 29.

Ostrya, 47. virginiana, 47.

OXALIDACEAE, 85 .

Oxalis, 85. corniculata, 85 . stricta, 85 . violacea, 85 .

Ox-eye Daisy, I23.

Painted Cup, II4.

Palmately-leaved Violet, 95.

Panax, 97. trifolium, 97.

Panicled Dogwood, Ioo. Phlox, 107.

Papaveraceae, 68.

Papaw, 66.

Parsley Family, 97.

Parsnip, Cow, 99.

Pasture Rose, 79.

Pea, Marsh, 85. Wild, 85.

Peach-leaved Willow, 42.

Pedicularis, II4. canadensis, II4.

Pennsylvania Bitter Cress, 73.

Peppergrass, $7 \mathrm{I}$. Wild, $7 \mathrm{I}$.

Phlox, I07. bifida, 108. Blue, 107. Cleft, I08. divaricata, 107. maculata, I07. Panicled, I07. paniculata, 107. pilosa, 107. Pilose, 107.

Wild Sweet William, I07.

Physocarpus, 76 . opulifolius, 76 .

Pignut, 47.

Pilose Phlox, I07.

Pimpernel, Yellow, 99.

Pin Oak, $5 \mathrm{I}$.

Pinaceae, 30.

Pine, 30.

Family, 30.

Northern Scrub, 3I.

Pitch, 3I.

Red, 3I.

Scrub, 3 I.

Southern Scrub, 3I.

White, 30. 
Pine, Yellow, 3 I.

Pink Family, 55.

Pinus, 30.

Banksiana, 3I.

echinata, 31 .

resinosa, 31 .

rigida, 31 .

Strobus, 30.

virginiana, $3 \mathrm{I}$.

Plane Tree Family, 75.

Plantaginaceae, II5.

Plantago, II5. cordata, II6. lanceolata, II6.

Plantain, Brook, I I6. Family, II 5 .

Plantain-leaved Everlasting, I2I.

Platanaceae, 75 .

Platanus, 76.

occidentalis, 76 .

Plum, Wild, 80.

Podophyllum, 66. peltatum, 66.

Polemoniaceae, io7.

Polemonium, I08.

Family, 107.

reptans, 108.

Polygala, 87 .

Senega, 87.

Polygalaceae, 87.

Polygonaceae, 55.

Polygonatum, 38 .

biflorum, 38 .

commutatum, 38 .

Pond Lily, Yellow, 58.

Poplar, Balsam, 44.

Poppy, Celandine, 69.

Family, 68.

Populus, 43.

balsamifera, 44 .

deltoides, 45.

grandidentata, 44 .

tremuloides, 44 .

Portulacaceae, 57.

Post Oak, 50.

Potentilla, 78.

Anserina, 79.

argentea, 78.

canadensis, 79 .

monspeliensis, 78 .

Prickly Ash, 87.

Gooseberry, 75 .

Primrose Family, I04.
Primulaceae, I04.

Prunus, 80. americana, 80. pennsylvanica, 80 . pumila, 80 . serotina, 80. virginiana, 80 .

Ptelea, 87. trifoliata, 87 .

Puccoon, III.

Pulse Family, 82.

Purple Azalea, I02. Flowering Raspberry, 8I. Purslane Family, 57. Speedwell, II4.

Pussy Willow, 43.

Pyrus, 76.

americana, 76 .

arbutifolia, 76 .

coronaria, 76 .

Quercus, 50.

alba, 50.

bicolor, 50.

coccinea, 52.

imbricaria, 7.

macrocarpa, 50.

Muhlenbergii, 50.

palustris, $5 \mathrm{I}$.

Prinus, 5 I.

rubra, 5I.

stellata, 50 .

velutina, 52 .

Ragwort, Golden, I23.

RaNunCUlaceae, 58.

Ranunculus, 59.

abortivus, 59 .

acris, 60 .

aquatilis, 59 .

bulbosus, 60 .

delphinifolius, 59.

fascicularis, 59.

recurvatus, 59 .

septentrionalis, 60 .

Rape, Broom. II5.

Raspberry, Black, 8I.

Dwarf, 8I.

Purple Flowering, 8I.

Red, 80.

Red Cedar, 32.

Clover, 83.

Haw, 78. 
Red Maple, 9г.

Mulberry, 53.

Oak, 5 I.

Raspberry, 8o.

Red-berried Elder, I 20.

Redbud, 82.

Red-osier Dogwood, Ioo.

Rhododendron, ror. nudiflorum, I02. viscosum, ror.

Rhus, 89. canadensis, 89.

Rib-grass, II6.

Ribes, 75 .

Cynosbati, 75 .

floridum, 75 . oxyacanthoides, 75 .

River Birch, 48. Grape, 93.

Robinia, 84. pseudacacia, 84 .

Rock Cress, 73. Cress, Smooth, 73.

Rockrose Family, 94.

Rosa, 79.

blanda, 79.

carolina, 79 .

humilis, 79 .

ROSACEAE, 76.

Rose Family, 76.

Pasture, 79.

Swamp, 79.

Wild, 79.

Rosemary, Bog, I02.

Rough Cinquefoil, 78.

RubiaceAe, i 6 6.

Rubus, 80.

allegheniensis, $8 \mathrm{I}$.

hispidus, 8I.

idæus, 80.

occidentalis, 8I.

odoratus, 8I.

triflorus, 8I.

villosus, $8 \mathrm{I}$.

Rudbeckia, I2I.

hirta, I2I.

Rue Anemone, 6 I.

Early Meadow, 60.

Family, 86.

RutAceae, 86.

SalicaceAe, 42.

Salix, 42. amygdaloides, 42 . cordata, 43.

discolor, 43.

longifolia, 43.

nigra, 42.

Sambucus, I20.

racemosa, 120.

Sand Cherry, 80.

Sand-bar Willow, 43.

Sandalwood Family, 54.

Sandwort, 56.

Sanguinaria, 68. canadensis, 69.

Santalaceae, 54 .

SAPINDACEAE, 92.

Sarsaparilla, Wild, 97.

Sassafras, 67, 68. variifolium, 68 .

Saxifraga, 74. pennsylvanica, 74 . virginiensis, 74 .

SAXifragaceae, 74.

Saxifrage, Early, 74.

Family, 74 .

Swamp, 74.

Scarlet Oak, 52.

Scrophularia, II3. marilandica, II3.

SCROPH UlariacEAE, II 2.

Seneca Snakeroot, 87.

Senecio, I23.

aureus, I23.

Service Berry, 77.

Shadbush, 77.

Shingle Oak, 7.

Shepherd's Purse, 7 I.

Shepherdia, 96. canadensis, 97.

Shooting Star, I05.

Silene, 57. antirrhina, 57.

Silver Maple, 91.

Weed, 79.

Silvery Cinquefoil, 78.

Sisyrinchium, 4I. augustifolium, 4I.

Skunk Cabbage, 33.

Sleepy Catchfly, 57 .

Slippery Elm, 52.

Small Solomon's Seal, 38.

Small-flowered Buttercup, 59.

Smilacina, 36. racemosa, 36 . 
Smilacina stellata, 37 .

Smilax, 40. herbacea, 40.

Smooth Alder, 49.

Gooseberry, 75.

Rock Cress, 73.

Snakeroot, Seneca, 87.

Snowberry, I 18.

Soapberry Family, 92.

SolanacEaE, II 2.

Solanum, II2.

Dulcamara, I 2 .

Solomon's Seal, False, 36.

Large, 38.

Small, 38.

Sour Gum, IOI.

Sparganiaceae, 32.

Sparganium, 32.

eurycarpum, 32.

Speckled Alder, 49.

Speedwell, II3.

Purslane, II 4.

Thyme-leaved, I I4.

Spice Bush, 68.

Spiderwort Family, 34.

Spring Beauty, 58.

Cress, 73.

Spurge, Cypress, 88.

Family, 88.

Squirrel Corn, 70.

Staff Tree Family, 90.

Staphylea, 90.

trifolia, 9I.

StAPHyleaCEAE, 90.

Star Flower, 105.

Stellaria, 56.

media, 56 .

Strawberry, 78 .

Strawberry Bush, Io.

Stylophorum, 69.

diphyllum, 69.

Sugar Maple, 9I.

Sumac, Fragrant, 89.

Summer Grape, 92.

Swamp Blackberry, 8I.

Buttercup, 60.

Honeysuckle, ror.

Rose, 79.

Saxifrage, 74 .

White Oak, 50.

Sweet Birch, 48.

Cicely, 98.

Fern, 45.
Flag, 34.

Gale Family, 45.

Viburnum, I I9.

White Violet, 95.

Sycamore, 76.

Symphoricarpos, I18. racemosus, i 18 .

Symplocarpus, 33. fœtidus, 33 .

- Tænidia, 99. integerrima, 99.

Tall Blackberry, 8I.

Tamarack, $3 \mathrm{I}$.

Taraxacum, I24. officinale, I25.

TAXACEAE, 30 .

Taxus, 30. canadensis, 30 .

Tea, Labrador, IoI.

Thalictrum, 60. dioicum, 60 .

Thuja, 32. occidentalis, 32.

Thy Melaeaceae, 96.

Thyme-leaved Speedwell, II4.

Tiarella, 74. cordifolia, 74 .

Tickseed, 122.

Tilia, 93. americana, 93.

Tiliaceae, 93.

Toadflax, II2. Bastard, 54.

Toothwort, 72.

Tradescantia, 34 .

Trailing Arbutus, I03.

Trembling Aspen, 44.

Trientalis, I05. americana, 105.

Trifolium, 83 .

hybridum, 83 .

pratense, 83 . repens, 83 .

Trillium, 39. cernuum, 40. erectum, 39. grandiflorum, 40. recurvatum, 39. sessile, 39 . undulatum, 40 .

Triosteum, II8. perfoliatum, iI8. 
Tsuga, $3 \mathrm{I}$. canadensis, $3 \mathrm{I}$.

Tufted Loosestrife, I04.

Tulip Tree, 65 .

Ulmus, 52.

americana, 52 .

fulva, 52 .

UMBELLIFERAE, 97.

URTICACEAE, 52.

Uvularia, 35. grandiflora, 35 . perfoliata, 35 .

Vaccinium, I03. corymbosum, I04. pennsylvanicum, I04. vacillans, I04.

Veratrum, 34 . viride, 34 .

Veronica, II 3 . officinalis, I I3. peregrina, II4. serpyllifolia, II4.

Vetch, 84.

Viburnum, II9. acerifolium, II9.

Lentago, II9.

Maple-leaved, II9.

prunifolium, II9.

pubescens, II9.

Sweet, II 9 .

Vicia, 84.

americana, 84 . caroliniana, 84 .

Vine Family, 92.

Viola, 95.

blanda, 95 .

canadensis, 95.

conspersa, 96.

cucullata, 95.

lanceolata, 95.

palmata, 95 .

pedata, 95 .

pubescens, 95 .

sagittata, 95.

Violaceae, 94.

Violet, Arrow-leaved, 95.

Bird-foot, 95.

Canada, 95.

Common Blue, 95.

Dog's-tooth, 36.

Family, 94.
Lance-leaved, 95.

Pålmately-leaved, 95.

Sweet White, 95.

White, 95.

White Dog's-tooth, 36 .

Wood Sorrel, 85.

Yellow, 95.

VitACEAE, 92.

Vitis, 92.

aestivalis, 92.

cordifolia, 93.

Labrusca, 92.

vulpina, 93.

Waahoo, 90.

Wake Robin, 39.

Walnut, Black, 46 .

Family, 45.

Water Lily Family, 58.

Waterleaf, rog.

Family, I08.

White Adder's Tongue, 36.

Ash, 106.

Baneberry, 64.

Birch, 49.

Cedar, 32.

Clover, 83 .

Dog's-tooth Violet, 36 .

Elm, 52.

Oak, 50.

Violet, 95.

Water Buttercup, 59.

Wild Black Cherry, 80.

Black Currant, 75 .

Crab, 77.

Garlic, 35 .

Geranium, 86.

Ginger, 55 .

Hyacinth, 36.

Lily-of-the-Valley, 37.

Pea, 85.

Peppergrass, 7 I.

Plum, 80.

Red Cherry, 8o.

Rose, 79.

Sarsaparilla, 97.

Strawberry, 78.

Sweet William, I0\%.

Willow, 42.

Black, 42.

Family, 42.

Peach-leaved, 42.

Pussy, 43. 
Willow, Sand-bar, 43.

Winter Cress, 72.

Winterberry, 89.

Wood Anemone, 62. Sorrel, 85.

Sorrel Family, 85.

Yarrow, 122.

Yellow Adder's-tongue, 36 .

Birch, 48.

Melilot, 83 .

Oak (see Chestnut Oak), 50.
Pimpernel, 99.

Water Buttercup, 59. Wood Sorrel, 85.

Yellow-eyed Grass, 4I.

Yew, 30.

Family, 30.

Zanthoxylum, 87 . americanum, 87 . Zizia, 99. aurea, 99. 




9153 


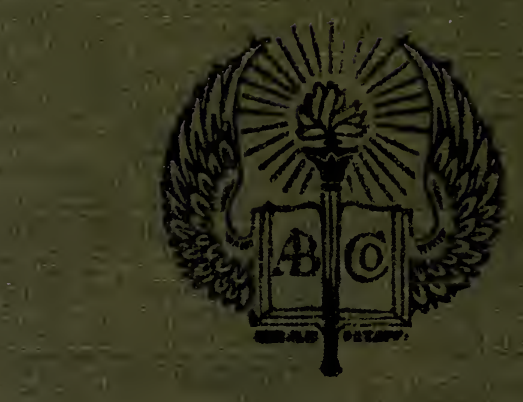

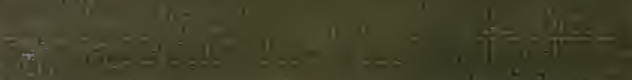

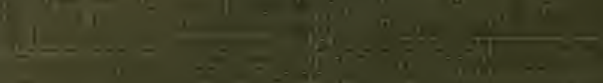

${ }_{3}{ }^{4} 11,-1$

Bark $=20$

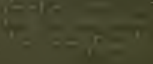

